\title{
Depositional Environment, Stratigraphy, and Vertical Hydraulic Conductivity of the St. Francois Confining Unit in the Fristoe Unit of the Mark Twain National Forest, Missouri
}

Water-Resources Investigations Report 00-4037

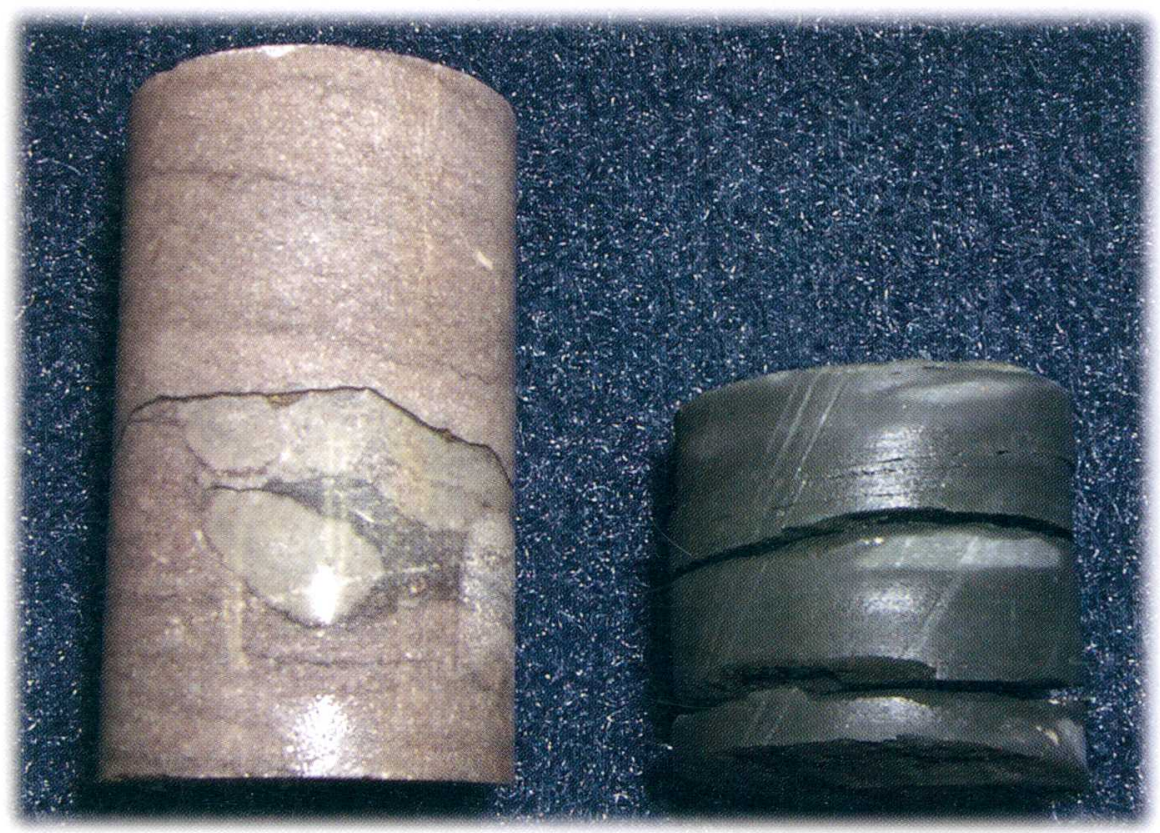

Prepared in cooperation with the

U.S. Department of Agriculture, Forest Service,

U.S. Department of the Interior, Bureau of Land Management,

U.S. Environmental Protection Agency, and

Missouri Department of Conservation 
Cover Photograph: Carbonate and shale rock core samples from exploration holes in the Fristoe Unit of The Mark Twain National Forest 


\section{Depositional Environment, Stratigraphy, and Vertical Hydraulic Conductivity of the St. Francois Confining Unit in the Fristoe Unit of the Mark Twain National Forest, Missouri}

By Michael J. Kleeschulte ${ }^{1}$ and Cheryl M. Seeger ${ }^{2}$

Water-Resources Investigations Report 00-4037

In cooperation with the

U.S. Department of Agriculture, Forest Service,

U.S. Department of the Interior, Bureau of Land Management, U.S. Environmental Protection Agency, and

Missouri Department of Conservation

Rolla, Missouri

2000

\footnotetext{
${ }^{1}$ U.S. Geological Survey

${ }^{2}$ Missouri Department of Natural Resources
} 


\section{U.S. Department of the Interior}

Bruce Babbitt, Secretary

\section{U.S. Geological Survey}

Charles G. Groat, Director

The use of firm, trade, and brand names in this report is for identification purposes only and does not constitute endorsement by the U.S. Geological Survey.

For additional information write to:

Copies of this report can be purchased from:

\section{District Chief}

U.S. Geological Survey 1400 Independence Road

Mail Stop 100

Rolla, MO 65401
U.S. Geological Survey Branch of Information Services

Box 25286

Denver, CO 80225-0286 


\section{CONTENTS}

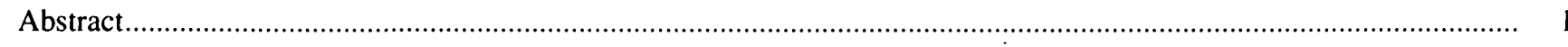

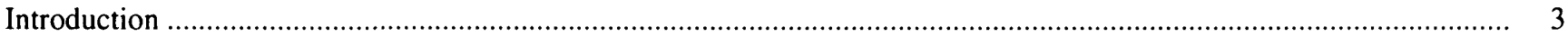

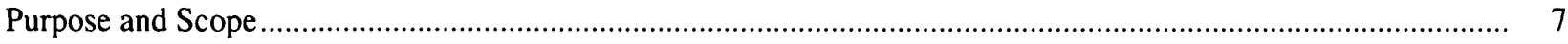

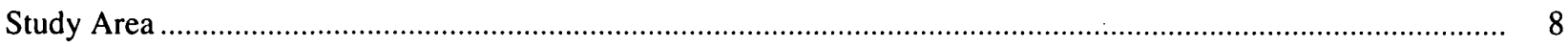

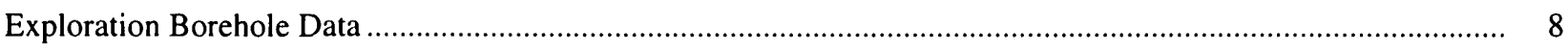

Rock Classification According to Depositional Texture …....................................................................... 8

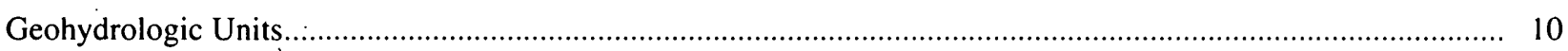

Lead-Zinc Deposit Exploratory History ............................................................................................ 10

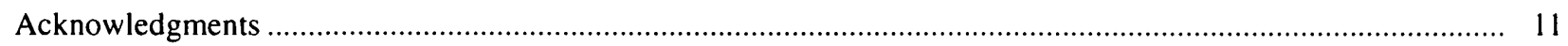

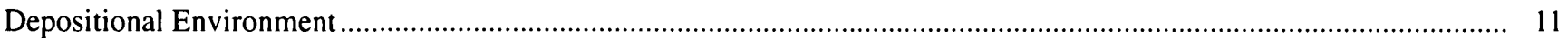

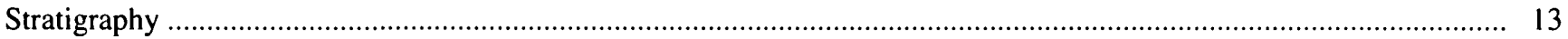

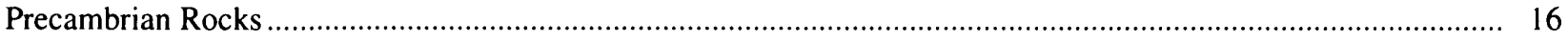

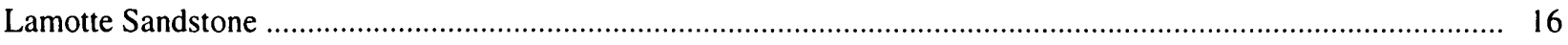

Lamotte Sandstone-Bonneterre Formation Transition Zone ........................................................................... 17

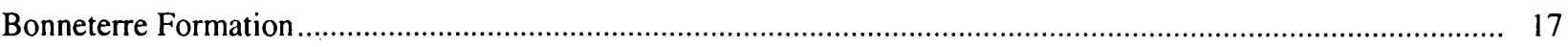

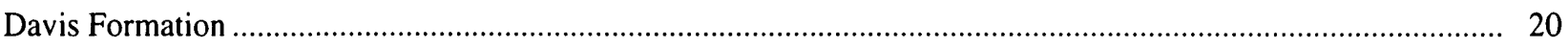

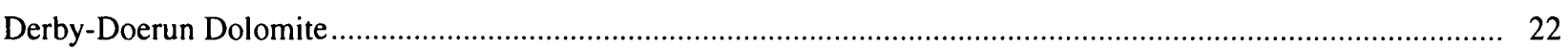

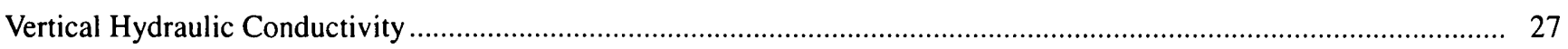

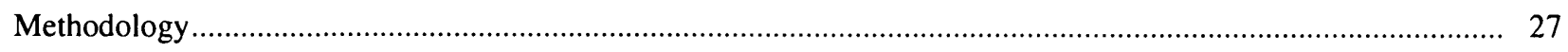

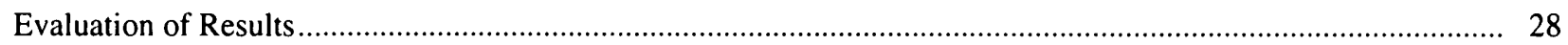

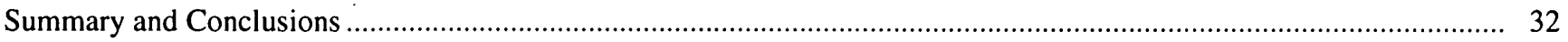

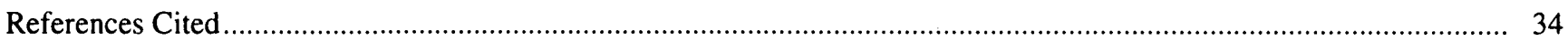




\section{FIGURES}

1. Map showing location of study area, Viburnum Trend, Precambrian-rock outcrops in the St. Francois Mountains, and the prospecting area

2. Simplified cross section from western Howell County to eastern Shannon County across the prospecting

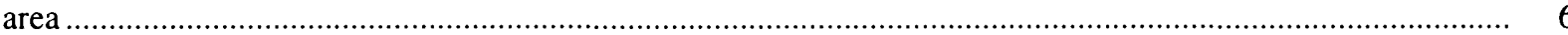

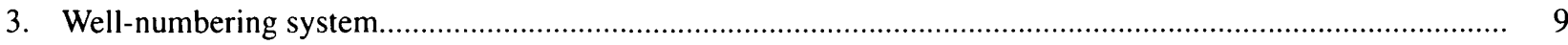

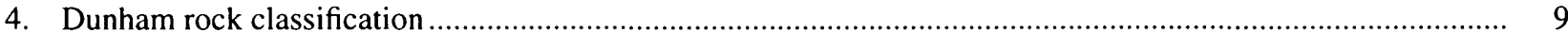

5. Schematic section of depositional conditions and lithologies showing facies development in the Viburnum Trend

6.-12. Maps showing:

6. Location of exploration borehole

7. Structure of the top of the Lamotte Sandstone 18

8. Structure of the top of the Bonneterre Formation .............................................................................. 21

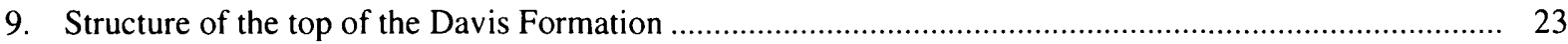

10. Structure of the top of the Derby-Doerun Dolomite .............................................................................. 24

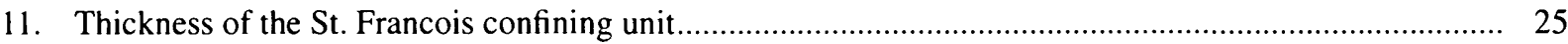

12. Net shale thickness of the St. Francois confining unit ....................................................................... 26

13. Boxplots showing the vertical hydraulic conductivities of formations and rock types in the Fristoe Unit and Viburnum Trend

\section{TABLES}

1. Core log analysis data

2. Porosity, vertical permeability, and vertical hydraulic conductivity data 


\title{
Depositional Environment, Stratigraphy, and Vertical Hydraulic Conductivity of the St. Francois Confining Unit in the Fristoe Unit of the Mark Twain National Forest, Missouri
}

\author{
By Michael J. Kleeschulte ${ }^{1}$ and Cheryl M. Seeger ${ }^{2}$
}

\section{Abstract}

The confining ability of the St. Francois confining unit was assessed in six townships (T2527N and R03-04W) of the Fristoe Unit of the Mark Twain National Forest in Oregon and Shannon Counties of southeastern Missouri. This was accomplished by describing the depositional environment and stratigraphy of the confining unit, and quantifying the vertical hydraulic conductivity of rock core samples from the confining unit using laboratory techniques. Stratigraphic data for this study were obtained by analysis of 238 exploration borehole core logs and rock core from exploration boreholes that typically described a 600- to 800foot interval from near the bottom of the Potosi Dolomite into the Lamotte Sandstone or Precambrian basement rock.

Faulting created a Precambrian highland area (St. Francois Mountains) and basins; erosion gave the Precambrian igneous knobs an irregular shape. This erosion and a marine transgression with continued deposition of clastic material led to the accumulation of sediments that formed the Lamotte Sandstone. Transgression caused shelf drowning and gradual development of a large intrashelf basin with a narrow, discontinuous rim (lowermost Bonneterre Formation) which allowed the carbonate-dominant facies to form. The transi-

\footnotetext{
${ }^{1}$ U.S. Geological Survey

${ }^{2}$ Missouri Department of Natural Resources
}

tion from shaley deposits with a limited stromatolite zone to carbonate with more frequent stromatolites suggest a general shallowing of the sequence as the Bonneterre Formation was deposited.

The Bonneterre Formation-Davis Formation contact denotes abrupt intrashelf basin development that was filled during cycles of transgression and shallowing. The intrashelf basin likely had a wide, continuous shelf rim producing the shale-dominant Davis Formation. The DerbyDoerun Dolomite was formed during a pair of carbonate depositional cycles. The basal shaley sequence represents a transition with the Davis Formation.

Thirty-three exploration holes penetrated Precambrian knobs that appear to intercept two linear structures or ridges that trend northwestsoutheast. These knobs generally protrude less than 200 feet above the surrounding Precambrian basement rock; however, some knobs along both of these ridges extend more than 500 feet above the surrounding basement rock.

The greatest thicknesses of the Lamotte Sandstone are 50 to 60 feet and it is present throughout the study area, except where it pinches out against some Precambrian knobs. The depth from land surface to the top of the Lamotte Sandstone, where present, ranges from 1,552 to 2,450 feet with an altitude ranging from a high of 502 feet below sea level to a low of 1,600 feet below sea level. Both of the Precambrian ridges can be 
identified as prominent structural high features or domes.

Algal reef zones in the upper part of the lower Bonneterre Formation are common and are well-defined digitate stromatolites; reef zones reach thicknesses of 100 feet. The depth from land surface to the top of the Bonneterre Formation ranges from 1,358 to 2,002 feet, and the altitude of the top of the formation ranges from 278 below sea level to 1,152 feet below sea level. The formation generally dips to the south or southeast. Evidence for the two Precambrian ridges in the study area can again be observed as domed features.

The Davis Formation is composed of interbedded shales and carbonate, with both shale- and carbonate-dominant sequences and ranges from less than 50 to more than 300 feet thick. The Davis Formation carbonates primarily are limestone, with dolostone at the top and base of the formation. The shales restricted the flow of dolomitizing fluids from reaching most Davis Formation limestones. The depth from land surface to the top of the Davis Formation ranges from 1,171 to 1,692 feet and the altitude of the top of the formation ranges from 200 to 878 feet below sea level. The structure map is similar to that of the top of the Bonneterre Formation, with the presence of the two linear highs in the study area and the dip of the formation to the south.

The Derby-Doerun Dolomite is composed of mudstones, grainstones, and mudstone-matrix boundstones. Thin shales are present throughout but shale content and bed thickness increases near the contact with the Davis Formation. The depth from land surface to the top of the Derby-Doerun Dolomite ranges from 970 to 1,598 feet, and the altitude of the top of the formation ranges from 18 feet above sea level to 788 feet below sea level. The Derby-Doerun Dolomite structure map is similar to that of the Davis Formation with the two structural highs in the study area and the general slope of the formation to the south.

The thickness of the St. Francois confining unit generally ranges from 250 to 375 feet in the study area. The net shale thickness of the St. Francois confining unit ranges from less than 50 feet in the northeast part of the study area to more than 150 feet in the southwest.

Laboratory vertical hydraulic conductivity and porosity analysis were performed on 88 core samples primarily representing the various rock types present in the St. Francois confining unit of the Fristoe Unit and the Viburnum Trend. Vertical hydraulic conductivity ranged from $8.70 \times 10^{-8}$ foot per second for one sample to less than $3.17 \mathrm{x}$ $10^{-14}$ foot per second (the reporting limit) for 39 samples. The porosity values ranged from a high of 17.47 percent to a low of 0.36 percent. There did not appear to be a strong correlation between the vertical hydraulic conductivity and porosity.

There is no significant difference ( $p$-value $=$ 0.375 ) between the ranked vertical hydraulic conductivity of samples collected from the DerbyDoerun Dolomite and Davis Formation in the Fristoe Unit. The interquartile range of vertical hydraulic conductivity shown for the DerbyDoerun Dolomite samples has more than an order of magnitude greater span than the interquartile range shown for the Davis Formation samples.

In the Viburnum Trend, there is a statistically significant difference $(p$-value $=0.006$ ) between the ranked vertical hydraulic conductivity of the Derby-Doerun Dolomite and Davis Formation. Although the vertical hydraulic conductivity of both formations is small, the median vertical hydraulic conductivity of the Derby-Doerun Dolomite is more than an order of magnitude greater than the median vertical hydraulic conductivity for the Davis Formation.

There is no statistically significant vertical hydraulic conductivity difference ( $\mathrm{p}$-value = 0.790 ) in ranked samples from the Fristoe Unit containing carbonate or shale or both rock types. This is also true when comparing ranked samples containing carbonate or shale or both rock types from the Viburnum Trend ( $p$-value $=0.412$ ), even though carbonate rocks have more than an order of magnitude greater median vertical hydraulic conductivity than shales.

The net shale thickness is not the single controlling factor that determines the effectiveness of the confining unit. Because the vertical hydraulic conductivity of the carbonate rocks and shales in 
the confining unit are similar, the entire carbonateshale thickness is important in determining the effectiveness of the confining unit.

The estimated range of effective vertical hydraulic conductivity for the St. Francois confining unit in the study area was calculated to be a maximum of $1 \times 10^{-12}$ foot per second and a minimum of $3.0 \times 10^{-14}$ foot per second. These vertical hydraulic conductivity values are small allowing the St. Francois confining unit to effectively impede the flow of ground water between the Ozark aquifer and the St. Francois aquifer, unless preferred-path secondary permeability has developed along faults and fractures.

\section{INTRODUCTION}

Lead and zinc exploration in the Fristoe Unit of the Doniphan/Eleven Point Ranger District of the Mark Twain National Forest (hereinafter referred to as the Fristoe Unit) in southeastern Missouri has been ongoing since the 1960 s. In the late 1970 s and early 1980 s, the search intensified, resulting in several hundred exploration holes being drilled in the Fristoe Unit. This exploration focused on a possible southern extension of the Viburnum Trend (fig. 1) ore deposits located about 20 miles to the north.

In 1983, as a result of the exploratory drilling, two Preference Right Leases were submitted for areas in the Fristoe Unit. After the Preference Right Leases were submitted, the U.S. Department of Agriculture, Forest Service (Forest Service) and the U.S. Department of the Interior, Bureau of Land Management (BLM) made the decision to prepare an Environmental Impact Statement (EIS). The EIS study area was enlarged to include 119,000 acres of the Fristoe Unit that had reasonable potential for mineral leasing proposals (U.S. Department of Agriculture, Forest Service and U.S. Department of Interior, Bureau of Land Management, 1988).

After the EIS was completed, mining companies focused their attention on a smaller area of the Fristoe Unit (prospecting area; fig. 1), south of Winona. The prospecting area lies within a larger region of welldeveloped karst terrain with an extensive network of solution-enlarged fractures ranging from small channels to large conduits. The two largest springs in Missouri are in this area--Big Spring, which has an annual mean discharge of 447 cubic feet per second [ $\left(\mathrm{ft}^{3} / \mathrm{s}\right)$; Hauck and others, 1997], and Greer Spring which has an annual mean discharge of $346 \mathrm{ft}^{3} / \mathrm{s}$ (Hauck and others, 1999). Discharge from these springs helps sustain flow in two nationally designated streams; Big Spring flows into the Current River (Ozark National Scenic Riverway) and Greer Spring flows into the Eleven Point River (Eleven Point National Scenic River). The potential for lead-zinc mining in this environmentally sensitive karst area has concerned the Forest Service and BLM in regard to possible impacts that mining may have on the water resources of the area. The concerns include but are not limited to the effects that mine dewatering may have upon shallow water resources.

Predominantly carbonate rock sequences of the Lower Ordovician and Upper Cambrian Series (Jefferson City Dolomite to the base of the Lamotte Sandstone) overlie the igneous granites and rhyolites of the Precambrian basement rock in the study area (fig. 2). The formations from the Jefferson City Dolomite to the Eminence Dolomite are predominant at land surface; these rocks, together with the Potosi Dolomite, form the Ozark aquifer, which is a primary source of water for private and public-water supplies and major springs (Imes and Emmett, 1994). The St. Francois confining unit lies beneath the Ozark aquifer and consists of the DerbyDoerun Dolomite and the Davis Formation. This confining unit impedes the circulation of water between the overlying Ozark aquifer and the underlying St. Francois aquifer, which consists of the Bonneterre Formation (the potential host formation for lead-zinc deposits; Wharton, 1975) and the Lamotte Sandstone. Little is known about the hydrology of the St. Francois aquifer because the shallower Ozark aquifer is a reliable source of ground water for the area. The geologic names used in this report follow the nomenclature used by the Missouri Department of Natural Resources, Division of Geology and Land Survey (DGLS).

The Bonneterre Formation is the potential host formation for lead-zinc deposits in the prospecting area. This formation is part of the St. Francois aquifer and the top of this formation is at depths greater than 1,300 feet in the prospecting area. Before potential lead-zinc deposits can be extracted, the mine area will have to be dewatered. If the overlying St. Francois confining unit is leaky, mine dewatering could result in lowering water levels in the shallow Ozark aquifer. Because the prospecting area is a possible extension of the Viburnum Tend, where lead-zinc mining is currently (2000) active, the geology and depositional environment in these two areas during Late Cambrian time when these formations were deposited may be similar. 


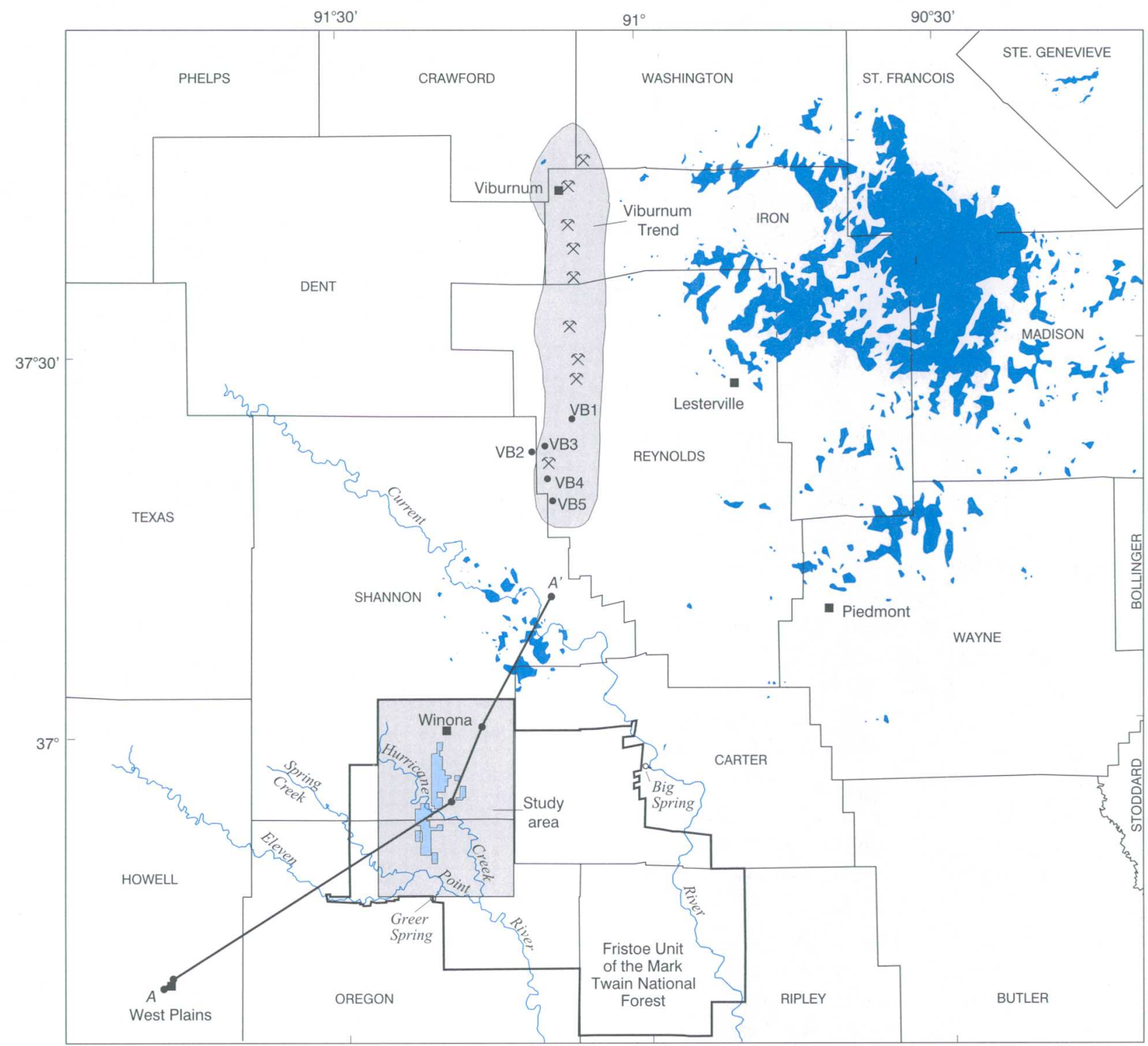

Base from U.S. Geological Survey digital data, 1:100,000, 1994 Universal Transverse Mercator projection, Zone 15

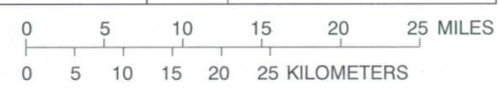

EXPLANATION
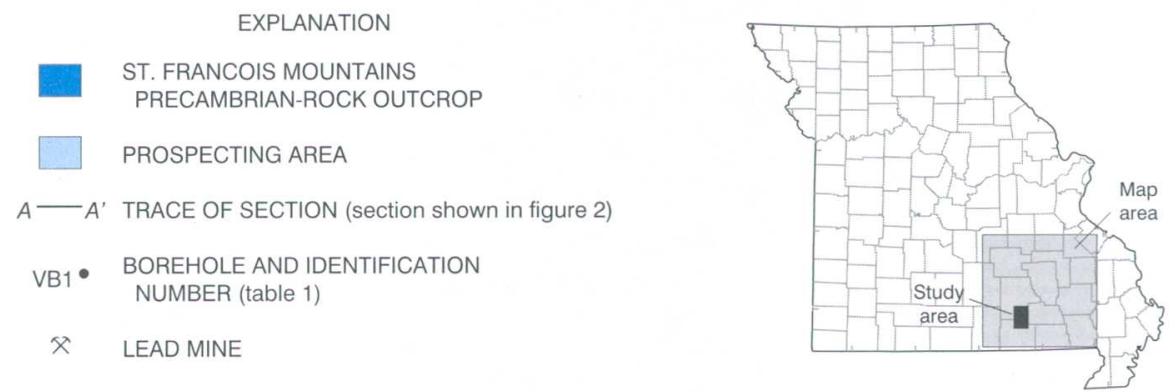

Figure 1. Location of study area, Viburnum Trend, Precambrian-rock outcrops in the St. Francois Mountains, and the prospecting area. 


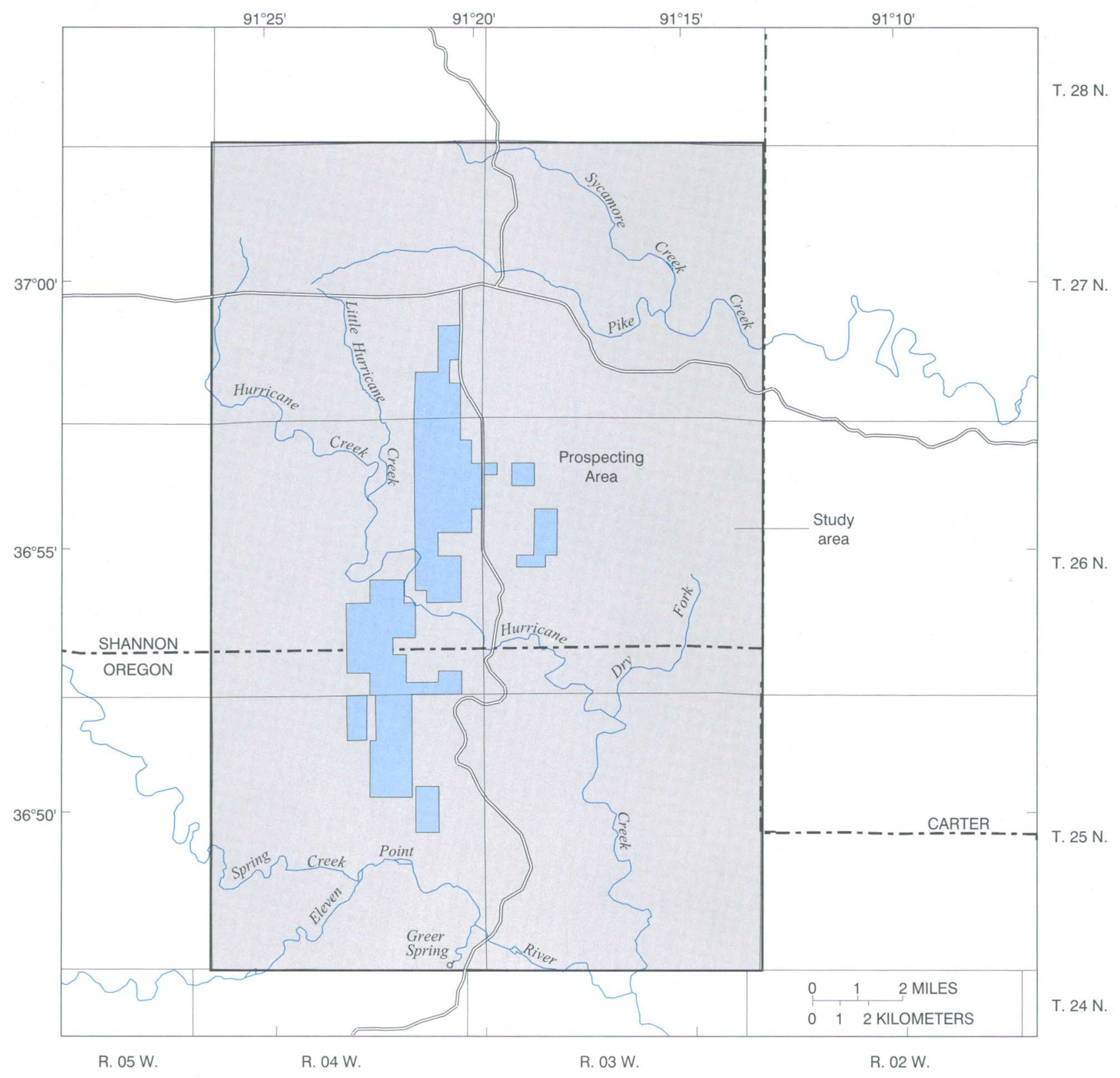

Figure 1. Location of study area, Viburnum Trend, Precambrian-rock outcrops in the St. Francois Mountains, and the prospecting area-Continued. 


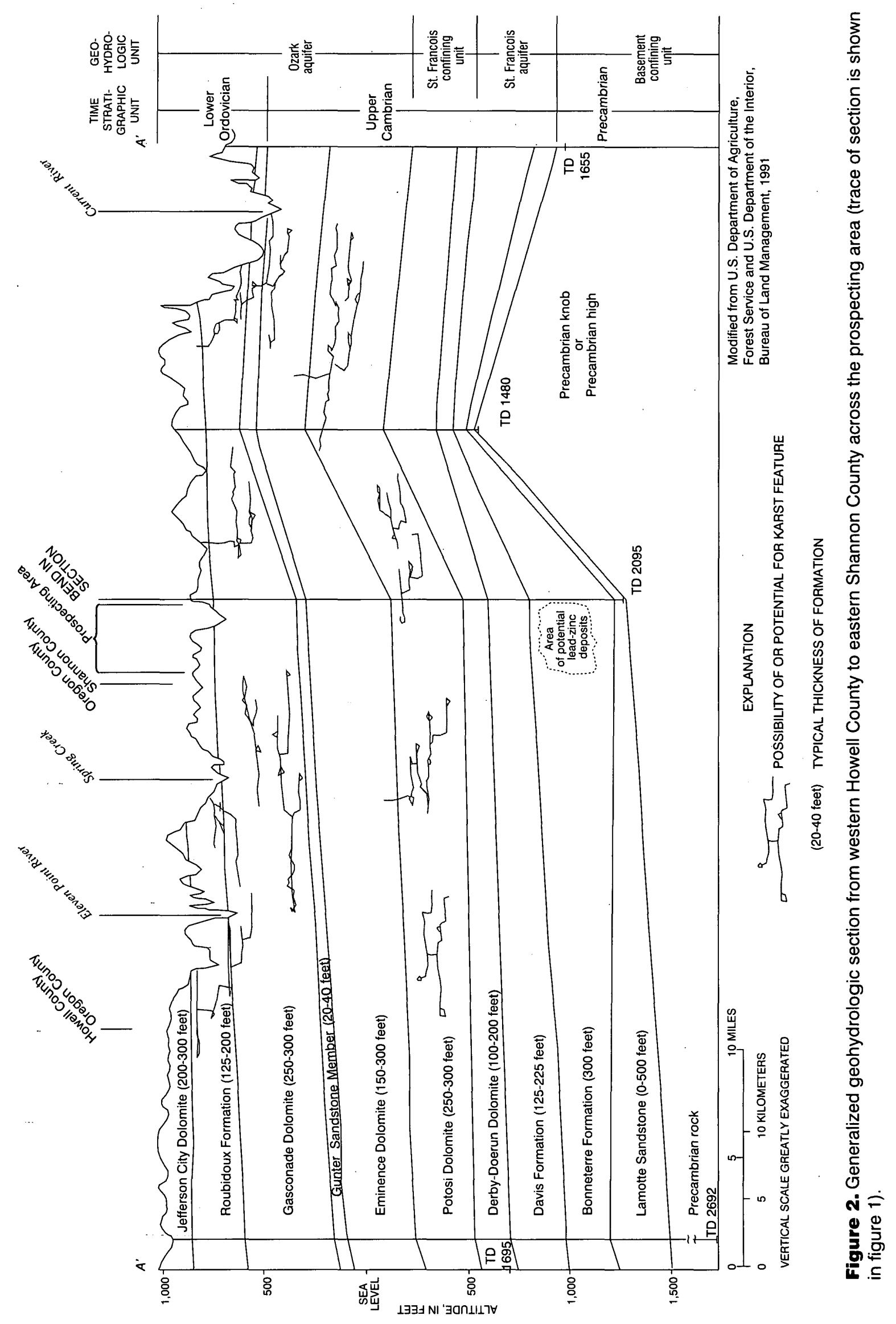


Extensive studies performed in the Viburnum Trend by Palmer (1991) and Thacker and Anderson (1979) indicate the environment that existed when the St. Francois confining unit was deposited affects the mud content of deposited sediments, which in turn affects the confining ability of the formations.

In 1990, the first of several consecutive geohydrologic studies was started in and adjacent to the Fristoe Unit. As a result of these studies, baseline hydrologic information was collected (Kleeschulte and Sutley, 1995) to help understand the natural flow rates of streams, water quality in surface and ground water, ground-water level fluctuations, and ground-water flow in the aquifers. Ground-water-level mapping and dye-trace studies have shown the presence of a groundwater trough between Hurricane Creek, which is adjacent to the prospecting area, and Big Spring. This indicates the possible presence of a large-permeability conduit system in the area that supplies water to Big Spring from the Hurricane Creek Basin (Imes and Kleeschulte, 1995).

In 1995, the U.S. Geological Survey (USGS) and the DGLS began a study in the prospecting area that supplements the geohydrologic studies that have already been completed in the Fristoe Unit. This study was preformed in cooperation with the Forest Service, BLM, U.S. Environmental Protection Agency, and the Missouri Department of Conservation.

The purpose of this study was to determine the depositional environment, stratigraphy, and vertical hydraulic conductivity of the St. Francois confining unit to assess the confining ability of the confining unit in an area centered on the prospecting area. However, the scope of the project was expanded to include the formations of the St. Francois aquifer. The Bonneterre Formation (part of the St. Francois aquifer) has a transitional contact with the overlying Davis Formation of the St. Francois confining unit. By including a description of the formations of the St. Francois aquifer, the entire interval from the Precambrian basement rock to the Davis Formation was considered. A better understanding of the effectiveness of the confining unit in the area was obtained by also analyzing the vertical hydraulic conductivity of rock core from five boreholes (VB1-VB5; fig. 1) in the Viburnum Trend. The results of these analysis were used for comparison purposes with the results of the core analysis from the study area.

The overall confining ability of the confining unit could have been obtained by performing aquifer tests. However, because of the expected small hydrau- lic conductivity of the confining unit, the excessive depth of the confining unit, and the resulting installation costs for pumping and observation wells, this was economically prohibitive. Therefore, the alternative laboratory hydraulic conductivity analysis method was selected. It is understood that there are inherent restrictions associated with the results of the laboratory hydraulic conductivity analysis, such as the inability to account for the effects of secondary permeability features (faults and fractures) that may be present in the subsurface of the study area.

\section{Purpose and Scope}

This report assesses the confining ability of the St. Francois confining unit in six townships (T25-27N and R03-04W) of the Fristoe Unit of the Mark Twain National Forest in Oregon and Shannon Counties of southeastern Missouri. The first objective of this report was to describe the depositional environment of the St. Francois confining unit. This information was interpreted from descriptions on mining company borehole and water well logs, and from detailed logging of five borehole cores from the study area on file at the DGLS McCracken Core Facility in Rolla, Missouri. This discussion was expanded to include the St. Francois aquifer.

The second objective of the report was to describe the stratigraphy of the St. Francois confining unit. This not only included describing physical rock characteristics but also geologic structure and formation thickness. After the stratigraphic data were compiled, structure maps were prepared depicting the altitude of the top of formations in the St. Francois aquifer and confining unit. Other maps show the thickness of the St. Francois confining unit and the areal distribution of cumulative shale thicknesses (net shale thickness) in the confining unit.

The third objective of this report was to quantify the vertical hydraulic conductivity of rock core samples from the St. Francois confining unit in the study area. This was achieved by performing laboratory vertical permeability analyses on rock cores from exploration holes. Ground water obtained from the Bonneterre Formation was used as the transmitting fluid during the analysis, allowing the vertical permeability to be converted to vertical hydraulic conductivity. 


\section{Study Area}

Data for this report were collected from a fourcounty area of southeastern Missouri. However, the area of intense data collection (study area) for the core $\log$ and laboratory vertical hydraulic conductivity analysis consists of six townships (T25-27N and R03-04W) in the Fristoe Unit of Shannon and Oregon Counties. Core log data also were collected beyond the study area perimeter to aid in contouring formation structure; this expanded area included part of western Carter County (fig. 1). For comparison purposes, laboratory vertical hydraulic conductivity analysis also were performed on rock core samples from boreholes in the Viburnum Trend area in Shannon and Reynolds Counties.

\section{Exploration Borehole Data}

Several hundred exploration holes have been drilled by numerous mining companies during the decades of exploration for lead-zinc ore in and near the Fristoe Unit. Two hundred thirty eight exploration borehole core logs from in and near the study area were made available for study (table 1, at the back of this report) by the BLM, DGLS, and the Doe Run Company. The BLM receives copies of core logs from all exploration holes drilled on Federal lands, DGLS was donated copies of logs from several mining companies, and currently the Doe Run Company owns and operates all of the active mines in the Viburnum Trend. These sources have obtained copies of many of the exploration core logs from the various mining companies that have performed exploratory drilling in the study area. These logs provide general information such as location of the borehole, land surface altitudes at the borehole, depths to formation tops, and total depth of the hole. In some cases, the logs also provide detailed lithologic descriptions of the formations encountered from near the bottom of the Potosi Dolomite into the Lamotte Sandstone or Precambrian basement, typically an interval of 600 to 800 feet. These core logs along with a detailed study of core samples from five Amax Exploration, Inc. boreholes drilled in the study area (801-002, 801-009, 801-010, 801-016, and 801-031; table 1) provided the primary source of the detailed stratigraphic data contained in this report. Considerable interpretation was necessary in defining stratigraphy in some of the logs because of transitional lithologies and variable stratigraphic nomenclature that has been applied in the area.
In this report, the location of exploration boreholes is shown as the local well number (table 1) and follows the General Land Office coordinate system (fig. 3). According to this system, the first three sets of numbers of a hole location designate township, range, and section. The letters that follow indicate quarter section, quarter-quarter section, and quarter-quarter-quarter section. The quarter sections are represented by letters A, B, C, and D, in counterclockwise order, starting in the northeastern quadrant. Two or more exploration holes in the same division are numbered serially in the order they were inventoried.

\section{Rock Classification According to Depositional Texture}

Carbonate mud constitutes the bulk of many carbonate rock sequences. Sediment type and depositional environment (sediment deposited in calm water versus sediment deposited in agitated water) are two factors that influence the confining ability of rocks that are formed from these sediments. According to Larsen (1975), one way of classifying depositional environments is to focus on fine material that remained at the deposition site. In calm water, mud (particle size less than 20 microns) settles to the bottom and remains there, so mud-rich rocks are categorized differently than mud-free rocks, regardless of the amount and size of coarse-grained material in the rock.

Dunham (1962) defined five textural classes of carbonate rocks (fig. 4). These classes distinguish between mud-support, grain-support, and components that were bound together during deposition of the carbonate rock. These classes include:

Mudstone-Mud-supported carbonate rocks primarily composed of fine-grained carbonate mud and containing less than 10 percent grain-sized particles (quantity at which the grains become noticeable). The significance of mudstone is that it implies a calm-water or low-energy environment.

Wackestone-Mud-supported carbonate rocks in which grain-size particles are in excess of 10 percent, but are not so abundant as to support one another.

Packstone-Mud-rich carbonate rocks with grains so abundant they support one another (generally more than 65 percent grain-size particles). Grain support generally is a property of rocks deposited in an agitated-water or high-energy environment. Rocks exhibiting properties of both high- and low-energy depositional environments are peculiar. The unusual 


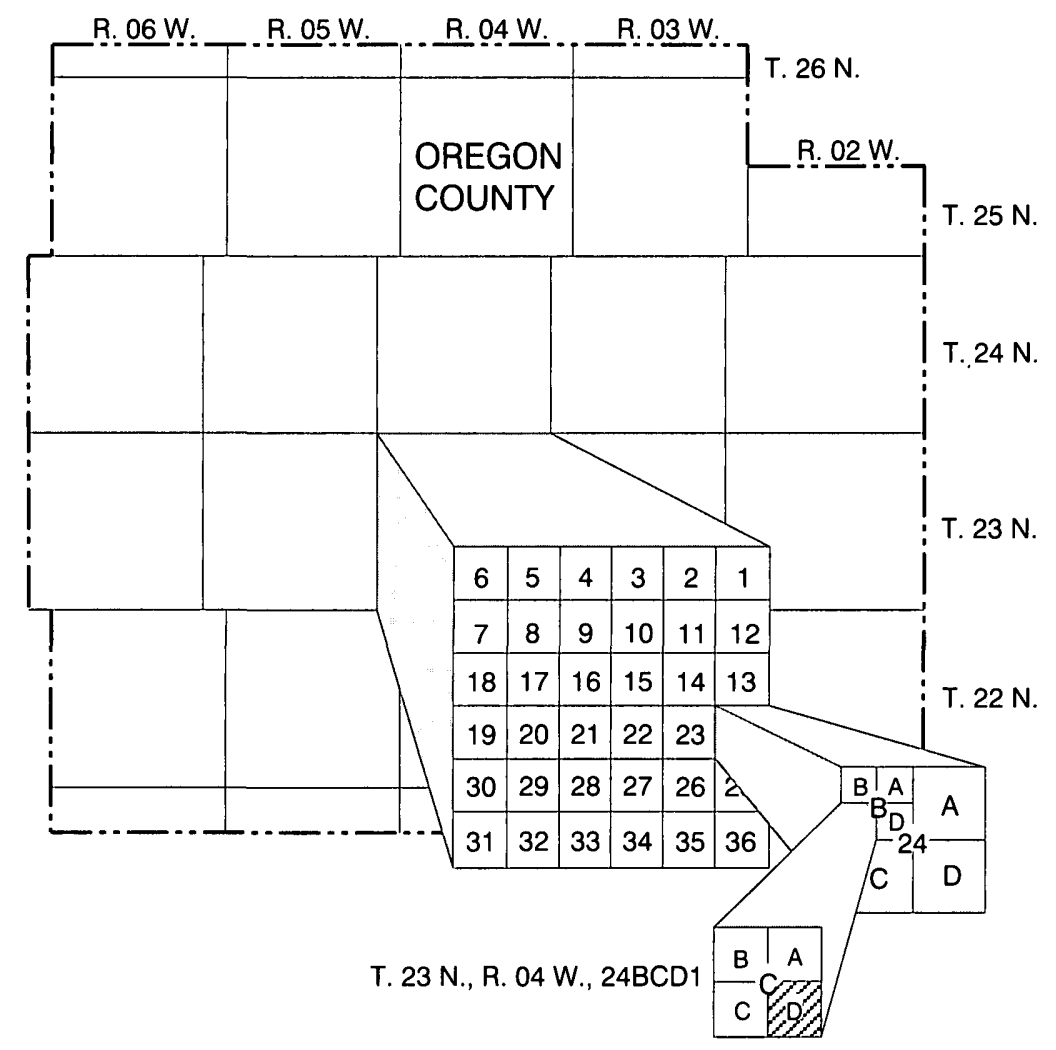

Figure 3. Well-numbering system.

properties may simply be a result of compaction of wackestone (especially where interstices are completely filled with mud), may indicate the introduction of mud-rich sediments into an area occupied by previously mud-free sediment, or may indicate the abundant production of grains in calm water.

Grainstone-Mud-free carbonate rocks that are grain-supported. Some grainstones are current laid, some are the result of mud being bypassed while locally produced grains accumulate, and some are the result of mud being winnowed from previously deposited mud-rich sediment. The class name merely denotes the absence of mud and that the grains are supported by each other.

Boundstone-Carbonate rocks that exhibit signs that the original components were bound together during deposition. These components exhibit intergrown skeletal matter (corals), lamination contrary to gravity (laminations of algal stromatolites), and cavities present on sediment floors that are too large to be interstices.

"Whiterock" is an additional term used in the lithologic descriptions and facies discussions in this report. The term originated during lead mining in southeastern Missouri and denotes back-reef (area between barrier reef structure and the exposed land mass) facies composed of planar algal stromatolites interbedded with burrowed carbonate sands and muds, with localized soft green clay (Howe, 1968). Both algal stromatolites and carbonates are bleached, dolomitized, and recrystallized to varying degrees. The back-reef facies is interpreted as representing a lowenergy zone above wave base in shallow water with restricted tides and circulation (Lyle, 1977). Whiterock horizons are present in much of the Upper Cambrian Series (Eminence Dolomite through the Lamotte Sandstone) of southern Missouri.

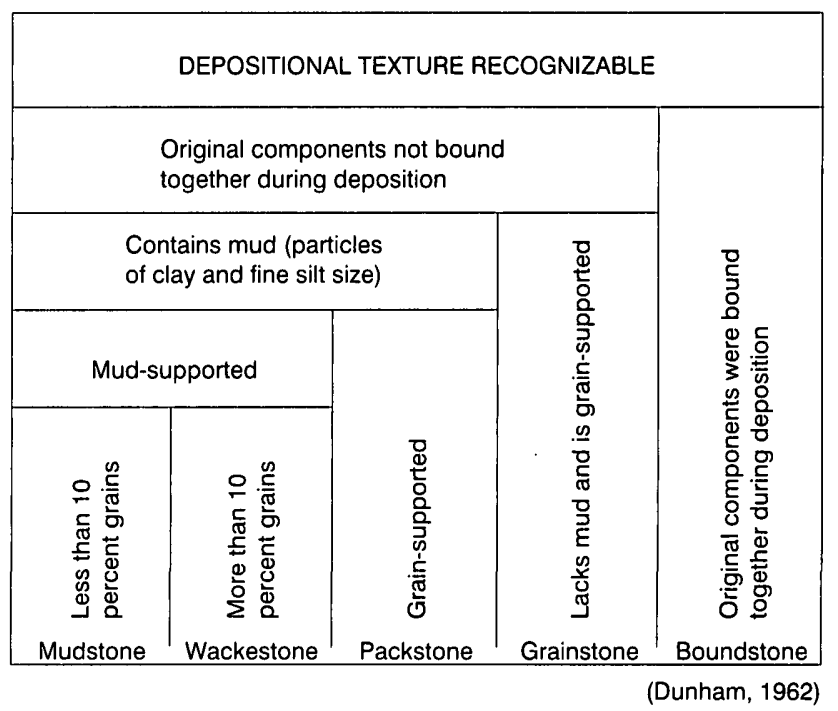

Figure 4. Dunham rock classification. 


\section{Geohydrologic Units}

Delineation of geohydrologic units is based on hydraulic properties and the hydrologic relation of each unit to adjacent geohydrologic units at a regional scale. The terms aquifer and confining unit, as defined regionally, may not adequately describe the hydraulic properties of a sequence of rocks locally because of the variation in water-yielding capability of the same sequence from one area to another.

The lowermost geohydrologic unit is the Basement confining unit which is dominantly granite and rhyolite. Imes (1989) states that this confining unit is virtually impermeable. In areas where extensive faulting and fracturing has occurred Imes reports the basement confining unit can yield small quantities of water. In areas where the unit crops out, well yields are less than 10 gallons per minute.

The St. Francois aquifer (Imes, 1990c) overlies the Basement confining unit and consists of the Bonneterre Formation and the Lamotte Sandstone. In areas of southeastern Missouri near the St. Francois Mountains where this aquifer is close to land surface, it yields adequate supplies of water for domestic and small capacity public-supply wells. The thickness of the St. Francois aquifer can vary considerably because of the rugged surface of the underlying Precambrian basement rocks.

The Derby-Doerun Dolomite and the Davis Formation form the St. Francois confining unit (Imes, 1990b) that overlies the St. Francois aquifer. Imes and Emmett (1994) state in their regional study of the Ozark Plateaus aquifer system that substantial secondary porosity and permeability have not developed regionally in the St. Francois confining unit. The finegrained nature of the formations indicates they have minimal permeability, even in areas containing little or no shale. The physical and hydraulic characteristics of the unit generally impede the circulation of ground water between the overlying Ozark aquifer and the underlying St. Francois aquifer (Imes and Emmett, 1994).

Common indicators of the effectiveness of a confining unit are the thickness and the shale content (usually a minimally permeable material) of the unit. Whereas these normally are good measures of the confining ability of a unit, other physical properties of the unit may alter the confining ability, including the degree of cementation of the rock and secondary permeability features that development in the rock such as solution channels, fractures, and faults (Imes, 1990b).
Because of the depths at which these units are found in the study area, the presence of the secondary permeability features in the units could not be assessed.

Although the characterization of the Ozark aquifer is not within the scope of this report, a general description of the unit is provided to show the significance of the unit in regard to the underlying confining unit. Being the uppermost geohydrologic unit in the study area, the Ozark aquifer (Imes, 1990a) consists of rocks from the top of the Jefferson City Dolomite to the base of the Potosi Dolomite (fig. 2). This predominantly carbonate aquifer is made up of dolostone and limestone with some sandstone and is the most widely used aquifer in southern Missouri. Ground water in the aquifer generally occurs under water-table conditions, which means the upper surface of the aquifer is at atmospheric pressure, and the water is not confined by less permeable rocks.

\section{Lead-Zinc Deposit Exploratory History}

The Bonneterre Formation is the prominent host formation for the major lead-zinc deposits located in southeastern Missouri. During the prospecting and mining of lead in eastern Missouri, the close correlation that exists between the ore deposits and stratigraphic traps, structural highs, and "reef" structures was discovered (Wharton, 1975). This relation provided the rationale used during the exploration for new ore bodies in the Viburnum Trend. As the ore deposits in the Viburnum Trend were being discovered and mined, the data gathered from extensive drilling and mapping provided new information about the depositional history and regional facies relation of the formations. Exploration in the Fristoe Unit in Shannon and Oregon Counties was directed at a potential extension of the Viburnum Trend (fig. 1). Much of the extensive geologic information that has been collected in the Viburnum Trend probably is transferable to the Fristoe Unit, especially information concerning the general description of the regional geologic setting and the depositional environment of the formations. A basic understanding of these factors gives insight as to the hydrologic characteristics of subsurface structural features and facies, which influence the confining ability of geohydrologic units. 


\section{Acknowledgments}

A special acknowledgment of gratitude is extended to Glenn Adams of the Doe Run Company for his assistance in obtaining rock core samples and for access to the core logs on file at the Doe Run Company. Much of the data in this report could not have been obtained without his cooperation.

\section{DEPOSITIONAL ENVIRONMENT}

The Late Cambrian depositional environments can be described only in general because of the extreme variability in the core descriptions and unequal core distribution (fewer data are available for the western one-third of the study area). For example, descriptions of the Bonneterre Formation (the target formation for mineral exploration) by different core loggers vary from brief one line descriptions to detailed descriptions several pages in length. Formations other than the Bonneterre Formation are typically described by no more than a few lines per formation. Also, various carbonaterock classification systems such as Dunham (1962) and Folk (1959) were used. Classification of carbonates as either packstone or grainstone often is difficult without extensive petrographic work in even slightly altered limestones. Often the limestone and dolostone were not differentiated within individual cores because these data were not necessary for the mining geologist. Relogging of cores with consistent terminology would be required for a thorough characterization of depositional environments and confirmation of the interpretations provided herein.

Faulting created a Precambrian highland area (St. Francois Mountains; fig. 1) and basins, and parts of this terrane underwent extreme erosion before deposition of Upper Cambrian alluvial and marine sediments. This erosion gave the more resistant Precambrian igneous knobs an irregular shape. They typically have steep sides, but are separated by broad flat valleys and where these Precambrian knobs are present, overlying formations can be thin or missing.

The overlying Upper Cambrian sediments are composed of alluvial and fluvial clastics that grade upward into marine sandstones and carbonates and are characteristic of intershelf basin areas. These sediments were deposited during repeated cycles of marine transgressions (spreading of the sea over land areas) and subsequent shallowing. The intershelf basin was a large basinal feature that formed on the regional shelf.
The intershelf basin covered much of southeastern Missouri, including the study area and the Viburnum Trend (Palmer, 1989). The deposited rock sequence in this intershelf basin area includes the following formations (in ascending order): Lamotte Sandstone, Bonneterre Formation (including the Sullivan Siltstone and Whetstone Creek Members), Davis Formation, DerbyDoerun Dolomite, Potosi Dolomite, and Eminence Dolomite. This sedimentation in southeastern Missouri was controlled by pre-Late Cambrian uplift and erosion of the igneous basement rock, and by faulting during the Late Cambrian Epoch. Most of southern Missouri was uplifted repeatedly throughout the Paleozoic Era, which includes the Cambrian and Ordovician Systems. This is evidenced by unconformity-bounded sequences between and within nearly every system in the Paleozoic Erathem (Palmer and Seeger, 1998).

The St. Francois Mountains (located about 45 miles to the northeast of the study area; fig. 1) and Precambrian knobs affected mineralization in the Viburnum Trend. During the Late Cambrian, the Precambrian highland area was east of the Viburnum Trend and a shallow water basin was to the north and west (fig. 5). The exposed Precambrian knobs in the basin were a major influence on the marine depositional environment in the area and affected the formation of island complexes. These island complexes were conducive for the development of algal reefs which were covered by sediments that later formed the Bonneterre Formation. A simplified schematic section of a typical buried reef structure (fig. 5) in the Viburnum Trend area, shows features that probably are common to the prospecting area.

Erosion of the Precambrian highlands and a marine transgression with continued deposition of clastic material led to the accumulation of sediments that formed the Lamotte Sandstone. The Lamotte Sandstone basal conglomerate is associated with fan deposits (alluvium deposited where streams flowed onto a lowland from the Precambrian knobs) (Houseknecht and Ethridge, 1978; Yesberger, 1982). These deposits can be divided into debris flows (sandstone matrix conglomerates) and mudflows (clay matrix conglomerates). Both types of fan deposits are described in the borehole logs. Coarseness of the alluvial deposits generally decreases with distance from the Precambrian highland area. Palmer (1991a) interpreted arkosic sections as gravel-based channel deposits, sandbars, laminated sheet-flood deposits, and overbank deposits (from bottom to top through each fining-upward 


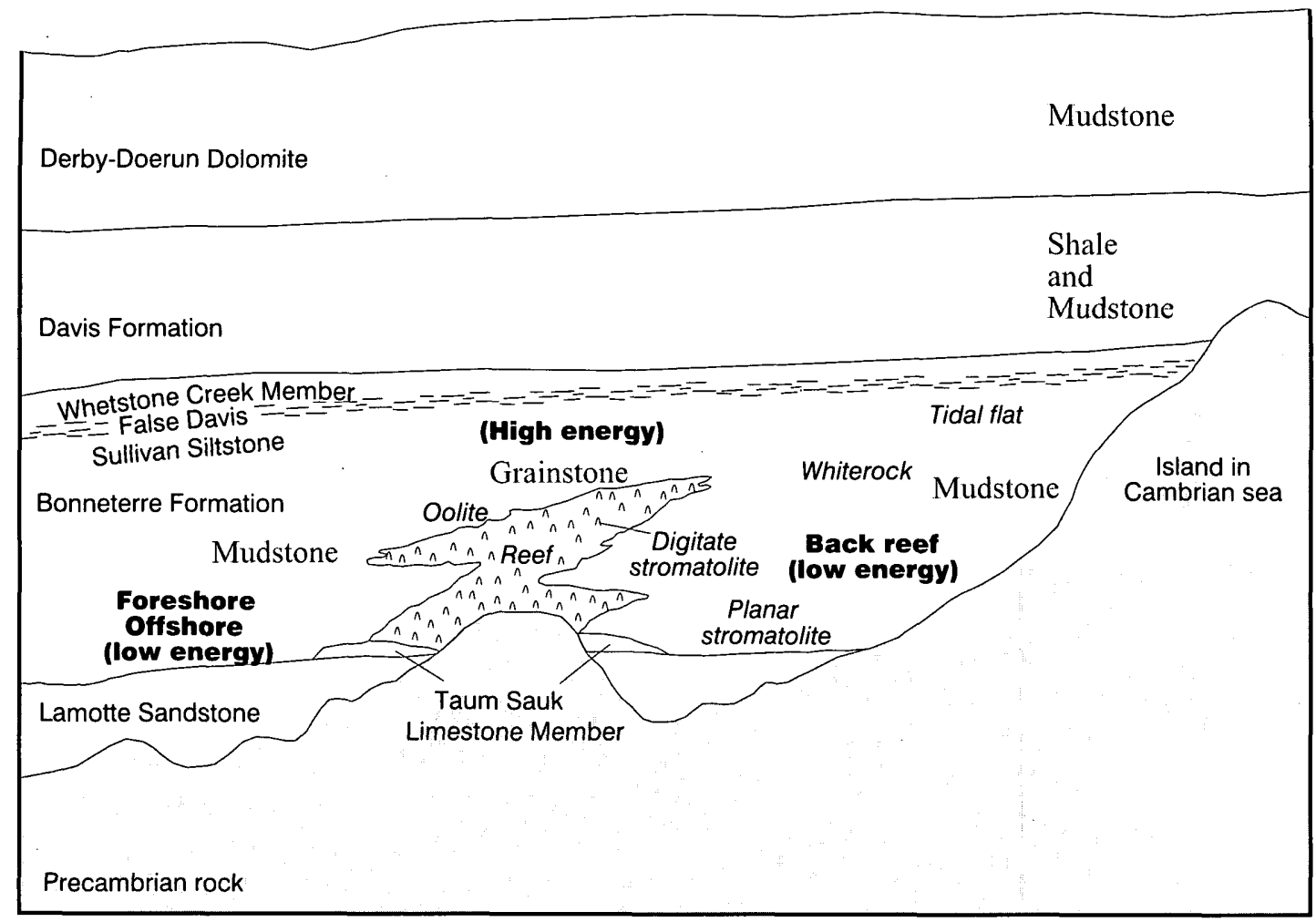

Figure 5. Schematic section of depositional conditions and lithologies showing facies development in the Viburnum Trend.

sequence). Arkosic deposits are also present near Precambrian knobs and generally these deposits thin with increased distance from knobs.

Conglomerate and arkose facies are conformably overlain by well-sorted, well-indurated (hard), fine- to medium-grained quartzose sandstone. Some cross-bedding and burrows are present in these facies. These facies are interpreted as normal marine sandstone, and may have been a near shore barrier and shallow tidal flat complex (Palmer, 1989, 1991a, 1991b).

Transgression caused shelf drowning and gradual development of a large intrashelf basin (Central Missouri Intershelf Basin) (Palmer, 1989). Interbedded sandstones and marine carbonates of the Lamotte Sandstone and Bonneterre Formation are included in sediments deposited in the transition zone where fan deltas were still active and discharged into tidal flats or shallow marine areas (Hayes and Knight, 1961; Yesberger, 1982). Differences between sandstone- and carbonate-dominated facies probably indicate distance from the clastic source (Precambrian highland area), with carbonate-dominant facies likely deposited farther from the source of the clastic material.
The lowermost shaley carbonate sequence of the Bonneterre Formation also suggests intrashelf basin deposition, when the basin margin was likely a narrow, discontinuous rim, allowing the carbonate-dominant facies to form. Interbedded shales are indicative of increased clastics coming into the basin, which periodically suppressed algal stromatolite growth. Stromatolitic zones indicate periods of limited clastic deposition and possible limited sedimentation. Between the lower shale-rich carbonates and the upper coarse crystalline dolostones, Bonneterre Formation rocks are mostly non-argillaceous (lacking clays and shales) and oolitic. The texture and alterations to the rock make identifying algal constituents in this sequence difficult and the rock is described as cryptalgal "reef" dolostones and grainstones. The transition from shaley deposits with a limited stromatolite zone to carbonate with more frequent stromatolites suggests a general shallowing of the sequence, with possible channel development. Oolitic horizons (indicative of near-shore, high-energy wave-action environment) with possible shoaling. 
Arkosic zones (up to 4 feet thick) may be interpreted in several ways. If the zones are interbedded with whiterock (indicative of shallow or subaerially exposed rock) or oolitic rocks, they may be a near shore facies and suggest proximity to a Precambrian knob. Alternately, if interbedded with only white- rock, the environment may have been alluvial channels. Finally, if they are interbedded with dark-colored mud-rich dolostones, they are more likely to be grain flows (small debris flows that moved farther offshore during storm events). Most core descriptions are not in sufficient detail to determine which depositional environment was present.

Several rock sequences show a cyclic pattern of deepening, then becoming shallow with whiterock present at the top of the shallowing-upward cycles. The whiterock thins toward the basin area. Reddened hematitic (iron oxide) patches remain in many whiterock sequences and grade outward to pale olive-green clayrich coarse-crystalline dolostone, suggesting that reddened limestones were the precursor to whiterock dolostone (Palmer, 1991a). Dissolution of the precursor limestones suggests that these areas were subaerially exposed. The Sullivan Siltstone Member is a transgressive clastic-dominated facies that occurs where the shelf surface was inclined at steeper angles. This may have been accompanied by southeastward-directed shelf subsidence that was filled with sediments that lessened the steeper angle shelf area (Larsen, 1977; Palmer, 1991a). Intraclast refers to sediments that were "torn up" by erosion, reworked, and then redeposited in the same basin to form a new sediment. Intraclast conglomerate beds are interpreted as possible storm-generated debris flow deposits that moved down slopes of only a few degrees (Palmer, 1991a). One core description in the northern part of the study area notes siltstone intraclasts, interpreted to have been formed where they were found; carbonate clasts in cores to the south are considered to have moved down slope from the source area and deposited.

The Bonneterre Formation sequence may change to nearly all limestone or all coarse crystalline dolostone in short distances. Retention of limestone in the basal part suggests that the southern and extreme northwestern parts of the study area were deeper offshore environments because generally near-shore carbonates are dominated by vuggy coarse-crystalline dolostone.

The Bonneterre Formation-Davis Formation contact denotes abrupt intrashelf basin development. The intrashelf basin continued to be filled during cycles of transgression and shallowing. The facies is a clastic sequence deposited within a regional carbonate shelf. The intrashelf basin likely had a wide, continuous shelf rim, as is suggested by the shale-dominant Davis Formation, unlike that of the basal Bonneterre Formation basin which had a narrow, discontinuous rim and carbonate-dominant facies. Horizontal burrows in the Davis Formation are suggestive of slow periodic deposition in a marine subtidal setting, where the shelf underwent gradual drowning during a slow transgression. Intraclast conglomerate beds can be interpreted as storm-generated flow deposits that presumably moved down slopes of only a few degrees or less. Individual cores with more abundant intraclast conglomerate layers suggest that those locations are near the intrashelf basin margin and consequently nearer to the source of the conglomerate. These facies tends to thin towards the geographic center of the shale depositional basins where there was less deposition.

The Derby-Doerun Dolomite was formed during a pair of carbonate depositional cycles. The formation includes sequences of thinly layered carbonate rock of differing composition (ribbon rock) that change upslope to sequences with thinner mudstone beds and thicker grainstone or packstone beds. Intraclast conglomerate beds (storm-generated debris flow deposits) presumably moved down slopes of only a few degrees. Abundant intraclast beds in individual cores may suggest that those locations were near the basin margin. The basal shaley sequence represents a transition with the Davis Formation.

Arkosic and porphyry conglomeratic material throughout the section indicates Precambrian highlands remained exposed during the Upper Cambrian carbonate deposition. Continued exposure of the Precambrian highlands may have been caused by the original height of the highlands, or be the result of continued uplift on fault-related structures.

\section{STRATIGRAPHY}

The 238 exploration boreholes from which the stratigraphic data were obtained (fig. 6) ranged from 1,478 to 2,590 feet deep. The borehole location recorded on the core log was determined either to the nearest quarter-quarter-quarter section or in feet from the north/south and east/west section line. Land surface altitudes were determined at the time of drilling using altimeters or topographic maps. The reported altitudes were verified during this study using USGS 7.5-minute 


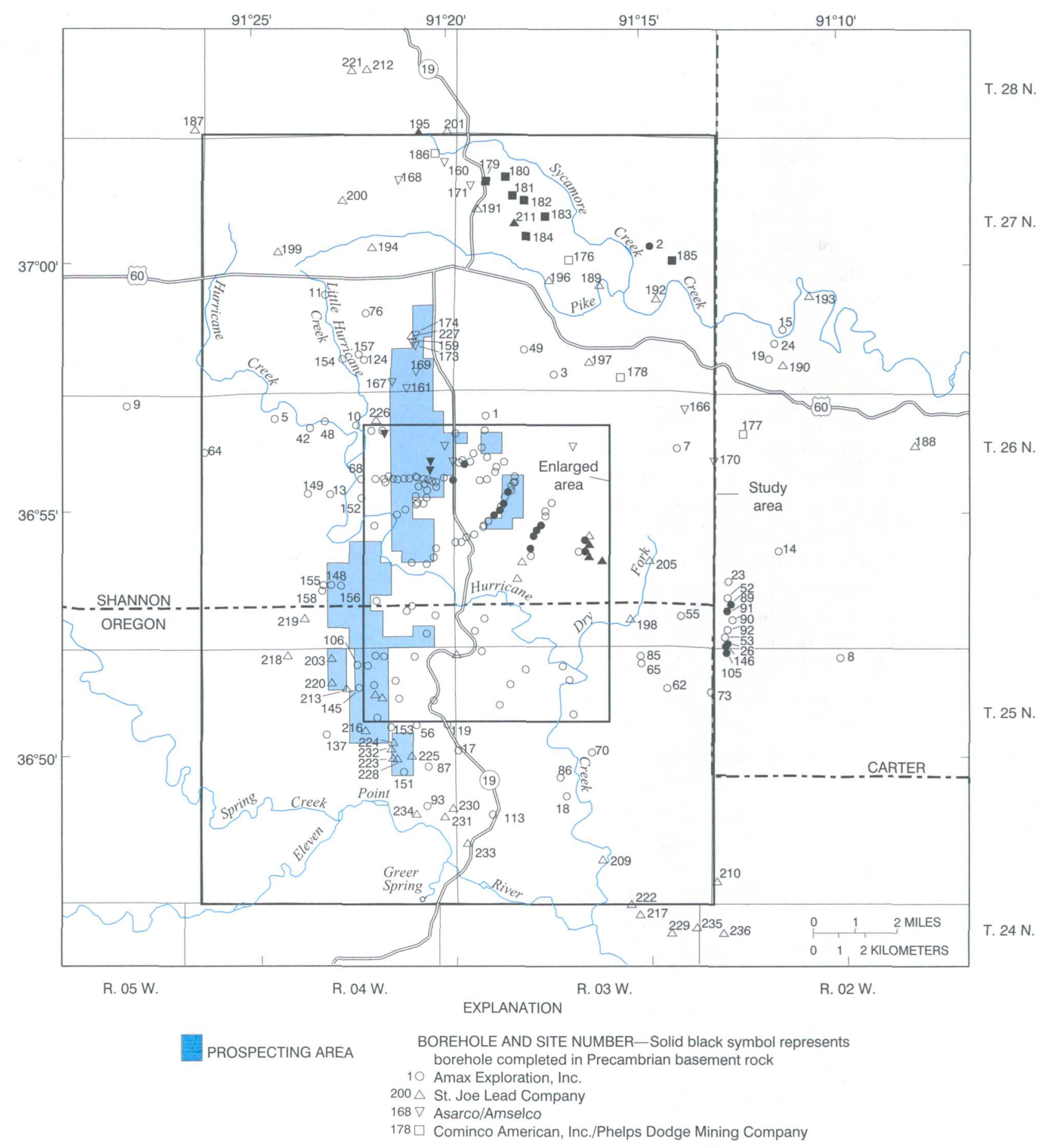

Figure 6. Location of exploration boreholes. 


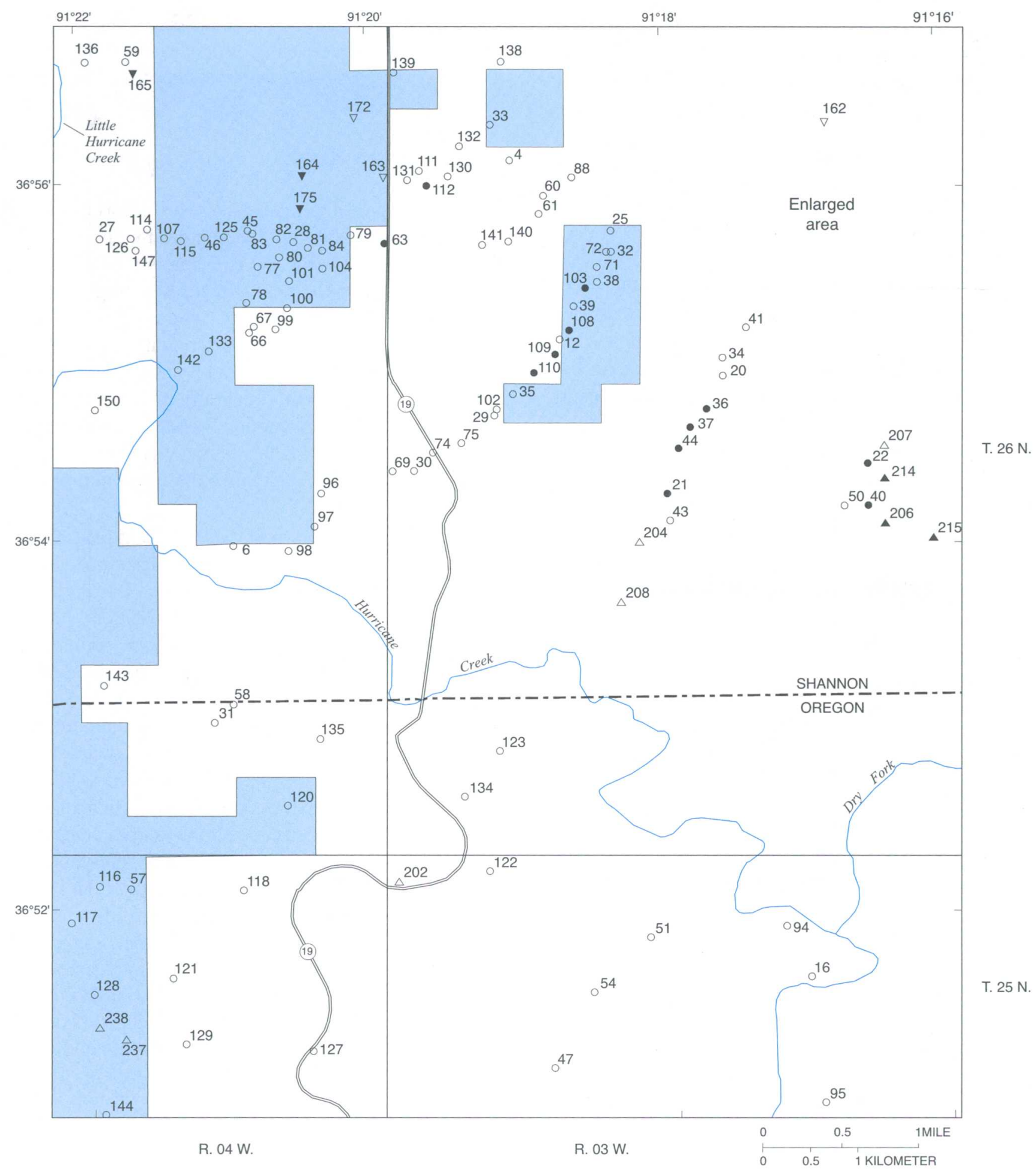

Figure 6. Location of exploration boreholes - Continued 
topographic maps that generally had contour intervals of 20 feet, making the land surface altitude accurate to about 10 feet (one-half the contour interval). In a few instances, the reported land surface altitudes on the core log did not agree with the land surface altitudes shown on the topographic maps for the given location. When this situation occurred, the altitude shown on the topographic map at the borehole location was used.

The altitudes used in contouring the formation tops of the Lamotte Sandstone, Bonneterre Formation, Davis Formation, and Derby-Doerun Dolomite were determined by subtracting the depth of the formation top reported on the core log from the land surface altitude. The thickness of the St. Francois confining unit also was mapped.

Because shale content usually is a good indicator of the effectiveness of a confining unit, core logs with detailed descriptions of lithologies were used to determine the net shale thickness of the Derby-Doerun Dolomite and the Davis Formation. These logs typically divided the cored section into small intervals in which the lithology had similar characteristics. The rock was described as to color, texture (mudstone, wackestone, packstone, grainstone, or boundstone), grain size, physical features present in the rock (algal stromatolites, vugs, and staining), and the percentage of each rock type (shale, dolostone, and limestone). Net shale thickness was calculated by multiplying the reported percent shale in an interval by the thickness of the described interval. The net shale thicknesses of all intervals were then summed to determine the total net shale thickness at that borehole location. Because most of the cores were not logged in sufficient detail to extract all the needed information to make a net shale thickness determination, these data are not as extensive as the data describing the altitude of the formation tops.

The Upper Cambrian sequence in the study area is a complex series of dolostones, limestones, shales, sandstones, and siltstones, with minor arkosic and conglomeratic layers. The lithologic summaries presented below are necessarily brief and focused on lithologic features that potentially affect hydraulic properties. Palmer (1989) contains a detailed discussion of the lithologic framework of the Upper Cambrian strata in southeastern Missouri. The Dunham classification system for carbonate rocks (Dunham, 1962) was used in this report where the Dunham system was applied by the core logger. Many dolostone "grainstone" may be "packstone", or should be termed "packstone-grainstone". Logs reported using other classification systems are described using Dunham classification terms.

\section{Precambrian Rocks}

Thirty-three core logs analyzed as part of this study described exploration boreholes that penetrated Precambrian knobs (fig. 6). The locations of these boreholes define two linear structures or ridges that trend northwest-southeast. One ridge is located along Sycamore Creek in the northeastern part of the study area and the other extends through the central part of the study area. The knobs generally protrude less than 200 feet above the surrounding Precambrian basement rock; however, some knobs along both of these ridges extend more than 500 feet above the surrounding basement rock.

Structural evidence of the Precambrian knobs or ridge in the central part of the study area appears to extend as high as the Roubidoux Formation. Based on altitudes of the contact between the Roubidoux Formation and Gasconade Dolomite, a structural dome was identified during geologic mapping of the area conducted in 1996 by the USGS (R.W. Harrison, U.S. Geological Survey, oral commun., 1996). In other areas where buried Precambrian knobs occur, structural domes have been mapped in overlying strata as high as 1,000 feet above the buried knobs. One explanation as to why the existence of Precambrian knobs can be indicated so far up in the geologic section is that younger horizontal sediment layers originally buried the Precambrian basement rocks in southeastern Missouri. Over time, loading on the buried sediments caused compaction and subsidence. Thick sediments deposited away from and on the flanks of the buried knobs subsided more than the much thinner sediments deposited directly over the knobs, creating the mappable structural domes (R.W. Harrison, oral commun., 1996).

\section{Lamotte Sandstone}

The Lamotte Sandstone is present throughout the study area, except where it pinches out against some Precambrian knobs. The greatest thicknesses of this formation indicated by borehole data are 50 to 60 feet. Most cores penetrated the Lamotte Sandstone (if present), but were terminated before the complete section was drilled. 
The Lamotte Sandstone is a white to light tan or gray, well-sorted, well-indurated mature quartzose sandstone. It generally varies from fine- to mediumgrained, but can be very coarse-grained. The sandstone has locally abundant burrows and small fossils (type not identified). Sandstones are dolomite-cemented in the upper part of the formation. Some dolostone is bleached, recrystallized, porous, and vuggy. Minor secondary calcite fracture fill and calcite- and dolomitelined vugs are reported.

Several cores contain Lamotte Sandstone that is all or partially arkosic or conglomeratic. Clasts are detrital porphyry fragments, and are supported by poorly sorted and angular feldspathic quartzose sandstone; clast size is up to 1 foot in diameter. The thickest conglomerate section is 33 feet; the thickest arkose section is 31 feet. Some clasts are scattered in thin beds throughout the sandstone, suggesting continual shedding of moderately worked material by erosion and/or continued uplift of the Precambrian highland area.

The depth from land surface to the top of the Lamotte Sandstone, where present, ranges from 1,552 to 2,450 feet, with an altitude ranging from a high of 502 feet below sea level (borehole 212, 1.5 mile north of the study area) to a low of 1,600 below sea level (borehole 236; 0.7 mile south of the study area) (table 1 , figs. 5,6 , and 7 ). The general dip of the formation is to the south or southeast. Both of the Precambrian ridges can be identified as prominent structural high features or domes. Along these ridges are several Precambrian knobs that protrude above the top of the surrounding Lamotte Sandstone. Superimposed on the dome structure in the central part of the study area are several local highs. A smaller structural high evident in the southeastern part of the study area (based on two boreholes) is adjacent to a structural trough that trends to the south. This trough is also a distinct feature on structural maps of overlying formations.

\section{Lamotte Sandstone-Bonneterre Formation Transition Zone}

The contact between the Lamotte Sandstone and Bonneterre Formation is marked by a transition zone. This transition zone is comprised of tan or light to medium gray medium-grained quartz sandstones with minor dolostone grainstone lenses. The sandstones exhibit some cross-bedding and mottling, have locally abundant glauconite that may be pelletal (fecal pellets), and are cemented by fine-grained brown dolostone. Several logs note scattered green to dark-green and dark-gray crepey (crinkled appearance) shale partings.

In several core intervals, the transition zone is pale to medium gray or tan to grayish-brown dolostone with localized sandstone lenses. The dolostone is shaley to sandy, fine to medium crystalline and fine- to medium-grained. Dolostones are grainstones, wackestones, and mudstones; the sequence appears to coarsen upward. Some mudstones are interbedded with grainstones, and scattered whiterock is reported. The dolostone is sometimes mottled, burrowed and bioturbated (sediment disturbed or agitated by organisms), and nodular. Secondary calcite and dolomite vug fill and calcite fracture fill is present. Irregular, wavy, dark gray-green to greenish-gray or dark gray argillaceous partings as much as 1 -inch thick are present. Dolostone porosity is noted, but no description of type or degree is given. Both sandstone- and dolostone-dominant core intervals contain detrital igneous lithic fragments.

\section{Bonneterre Formation}

Because of the importance of the Bonneterre Formation as the host rock for potential ore deposits, the formation is studied and described in much more detail in logs than the other formations. The Bonneterre Formation is dominantly carbonate, with several shaley horizons and a siltstone (the Sullivan Siltstone Member). The formation is missing from several cores because it pinches out against Precambrian knobs. The lower Bonneterre Formation is subdivided into a basal part composed of carbonate with interbedded shale and an upper part composed of dolostone with occasional shale layers or partings. Several logs note a basal sequence of the Taum Sauk Limestone Member (fig. 5).

The Taum Sauk Limestone Member is a light gray-white to greenish gray-white and red-mottled limestone with some dolostone. Where noted, the unit is generally found in the vicinity of the reef structures and is 20 to 40 feet thick. It is fine- to medium-grained and moderately argillaceous with red and green shale, and is locally burrowed.

The basal part of the lower Bonneterre Formation primarily is dolostone. Limestone is preserved in the southern and extreme northwestern parts of the study area. The basal unit ranges from 30 to more than 300 feet thick. The dolostones are comprised of mudstones to grainstones with mudstone-matrix bound- 


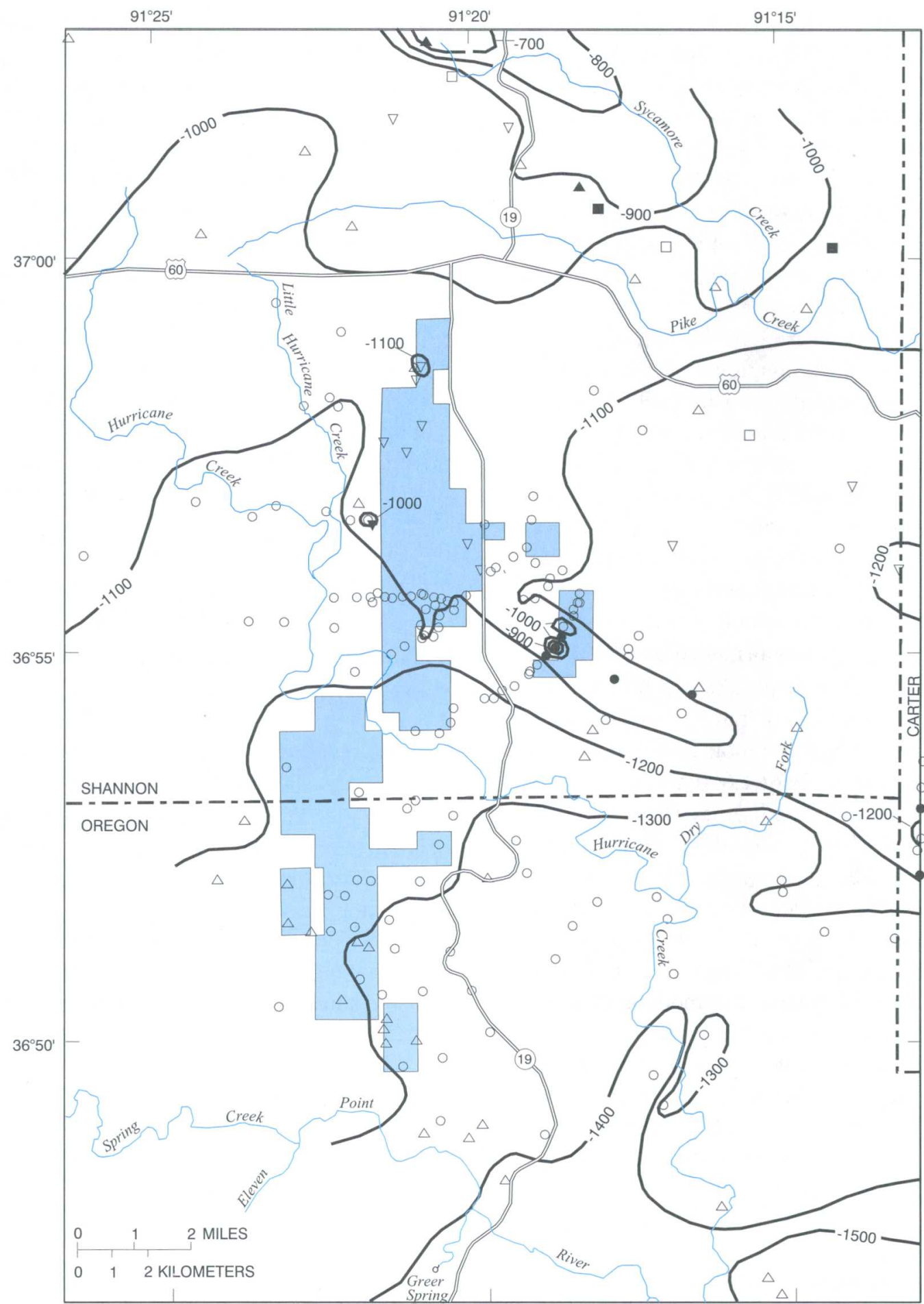

EXPLANATION

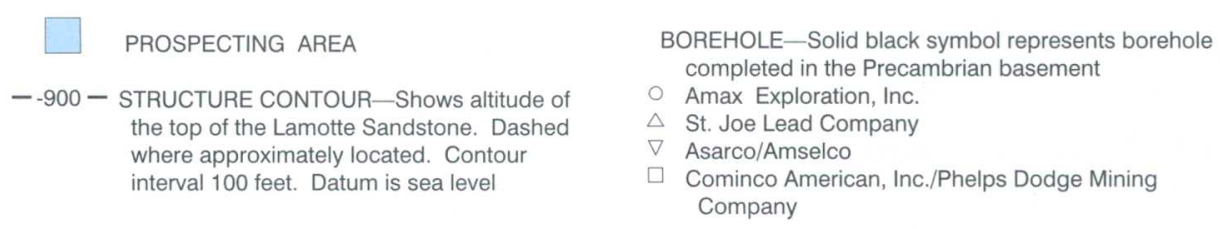

Figure 7. Structure of the top of the Lamotte Sandstone. 
stones and vary in color from gray to gray-tan, and tan. Argillaceous zones are pale green. Bleached zones suggest that parts of the section are whiterock. The dolostones are fine to medium crystalline, fine- to mediumgrained, and have interbedded quartzose-rich to arkosic layers (as much as 4 feet thick), primarily near the base (transition zone). Dark greenish-gray and gray to black shale is present in beds as much as 21 feet thick, and as wispy partings. Dolostones occasionally are mottled and have common bioturbation and burrowing. Algal structures are digitate (finger-like appearance) stromatolites as much as 1 foot high, occasional crypt-algal laminates, and minor hummocky algal forms. Grains are oolites and fossil fragments (type not specified); several logs note edgewise carbonate conglomerates. Minor porphyry conglomerate layers are noted in some core intervals. Structural features include infrequent scattered subvertical fractures, locally disrupted bedding, and, in one log, a 100-foot vertical slump structure. Solution features include scattered stylolites, and vugs partially to completely occluded by calcite spar and pink dolomite. Vugs are the most common form of visible porosity and often are reported in algal zones. Noted porosity generally is 5 percent or less.

Limestone core intervals range from 100 to 260 feet thick. They are more lithologically heterogeneous than equivalent dolostones, being comprised of mudstones and grainstones, with interbedded wackestones and mudstone-matrix boundstones. They are light gray, tan and pale greenish-gray, and are fine crystalline and fine- to medium-grained. The limestones commonly are burrowed, mottled, sparsely to moderately glauconitic, and contain carbonate intraclasts, fossil fragments (type not noted), oolitic layers, and digitate stromatolite zones. They have rare vugs and pores that are partially to completely occluded by pink dolomite and calcite spar. Occasional, thin dolostone layers are reported. Dark greenish-gray thin wavy-bedded shales are interbedded with the limestone. Shale percentages are higher in the limestones than in the dolostones; the shales probably restricted the movement of dolomitizing fluids. Dolostones similar to those described above bound the top and base of the limestone core intervals, and range from 20 to 70 feet thick.

The upper part of the lower Bonneterre Formation ranges in thickness from 40 to nearly 250 feet. It is composed of interbedded dolostone grainstones, mudstones, and grainstone- and mudstone-matrix boundstones, with occasional wackestones. The top of the unit generally is a grainstone underlain by whiterock.
The dolostones are fine- to medium-grained and fine through coarse crystalline. The coarse crystalline dolostones and reported bleached zones probably are whiterock. Color ranges from light to medium gray, gray-tan, pale greenish-gray, and brown. The dolostone often is mottled and is sometimes irregularly banded. Algal reef zones are common and are well-defined digitate stromatolites with infrequent hummocky algal features; reef zones reach thicknesses of 100 feet. Burrowing is also common in the unit. Clastic material includes occasional shale partings, and quartzose, arkosic, and porphyry conglomeratic layers. Solution structures include stylolites, possible solution breccias, and vugs partially to completely occluded by calcite spar and pink dolomite. Several descriptions note porosity, but are not specific as to type and nature. Scattered subvertical fractures sometimes are partially healed by calcite and/or dolomite.

The whiterock is comprised of fine- to coarsegrained dolostone with green to greenish-gray intercrystalline clay. It ranges in color from white to light gray, pale brown-gray, light tan, and light blue gray. Where clays have not entirely occluded intercrystalline pores, the dolostone appears very porous or vuggy. Matrix dolostone grains are sometimes visibly overgrown by medium-grained pink or white dolomite.

The Sullivan Siltstone Member (fig.5) is in the upper Bonneterre Formation, is 2.5 to 50 feet thick, and is composed of light to dark gray or brown, finely laminated, well indurated, fine- to medium-grained quartzose siltstone to sandstone. The unit thickens to the west and south. Siltstone is interbedded with thin dolostone lithoclast conglomerates, grainstone beds (primarily in the southern part of the study area), and scattered thin dark green to dark gray wavy shale partings. The siltstones have varying amounts of siliceous and dolomitic cement. Dolostones are tan, fine crystalline, and sometimes mottled, glauconitic, fossiliferous (type not noted), oolitic and/or porous. Solution vugs and brecciation are common in some dolostones. Brecciation is most commonly reported as soft-sediment deformation. Vugs have calcite, and contain trace sulfide mineralization which is most common in brecciated zones. Cores suggest that an incipient facies change to dolostone may be present in the north-central part of the study area.

The Whetstone Creek Member (fig. 5) ranges from 30 to 150 feet thick. The unit is dolostone with some limestone and limey dolostone, especially in the northwestern part of the study area. Color ranges from 
light to medium gray and grayish brown to tan, light blue gray, and greenish gray. Carbonates are fine to medium crystalline, fine- to medium-grained mudstones and grainstones, with wackestone-packstones and mudstone-matrix boundstones. Grainstones and wackestone-packstones are oolitic, fossiliferous (type not specified), and contain intraclasts. All carbonates are mottled, burrowed, and glauconitic. Mottled and finely laminated dolostones alternate. Unlike most Whetstone Creek Member sections in other areas of southeastern Missouri, these logs do not show abundant pelletal glauconite. Digitate stromatolites and crypt-algal laminates are noted; digitate stromatolites are more common to the north and laminate stromatolites to the south. Crypt-algal laminates are underlain by mottled dolostone, which is underlain by laminated dolostone. Solution features are stylolites and vugs with dolomite. Fracturing is present, but not common. Where reported, fractures generally are subvertical, with rare medium-angle fractures. Some fractures are healed by calcite. Porous zones are noted but extent and type are not described. Some whiterock is noted and reported bleached zones likely are also whiterock. Arkosic and igneous-conglomeratic layers are noted throughout the unit. Silt content is greater in the lower Whetstone Creek Member, near the contact with the Sullivan Siltstone Member.

Dark green shale partings are present throughout the Whetstone Creek Member. A prominent shale ( 1 to 27 feet thick) at the base of the unit is informally known as the False Davis (fig.5). Core descriptions are inadequate to determine if the False Davis is present throughout the study area. The shale is often interbedded with dolostone grainstones; the dolostones contain fossil fragments (type not identified), oolites, and occasional pyrite.

Based on 234 data points, the depth from land surface to the top of the Bonneterre Formation ranges from 1,358 to 2,002 feet. The altitude of the top of the formation ranges from 278 feet below sea level (borehole 179) to 1,152 feet below sea level (borehole 236; table 1, figs. 6 and 8 ) and generally dips to the south or southeast. Evidence for the two Precambrian ridges in the study area can again be observed as domed features. Also, the previously mentioned trough structure in the southern part of the study area is evident. The structure map of the top of the Bonneterre Formation indicates problems associated with using core logs from various sources to map formation tops. The fingering effect of the contours in the southern part of the prospecting area may be caused by different criteria used during core logging for identifying the top of the Bonneterre Formation, as opposed to the presence of structural features.

\section{Davis Formation}

The Davis Formation is composed of interbedded shales and carbonates, with both shale- and carbonate-dominant sequences. It ranges from less than 50 to more than 300 feet thick. The thinner core intervals are over Precambrian knobs. Shales generally are light to dark green, with some gray to dark gray beds. Individual shale layers range from partings to 5 feet thick. Shale-dominant sequences can be as thick as 50 feet, and contain as much as 90 percent shale. Limestonefilled burrows comprise the only carbonate in some shale layers. Carbonate layers in shale-dominant horizons vary from less than 1 inch to several feet thick. Carbonate-dominant zones may be 70 feet thick or greater. Shale percentages in these zones can be as much as 50 percent or less than 10 percent. Shale interbeds in carbonate-dominant zones vary from partings to several feet thick.

Davis Formation carbonates primarily are limestone, with dolostone at the top and base of the formation. The shales restricted the flow of dolomitizing fluids from reaching most Davis Formation limestones. The limestones are mudstone, grainstone, and mudstone-matrix boundstone, with some wackestone and occasional packstone. They are light tan to brown or gray to dark gray and light gray-tan in color. They are fine- to medium-grained and fine to medium crystalline. The limestones contain pellets, fossil fragments (type not specified), oolites, glauconite (some are pelletal), relict crypt-algal laminates and infrequent digitate stromatolites. Mudstones are sometimes bioturbated; burrows are horizontal and may be selectively dolomitized. Some layers are composed of carbonate intraclast conglomerate. Scattered vertical fracturing is present, but is less common than in formations above and below. Solution features include horizontal and vertical stylolites, and local solution and slump breccias. Scattered arkosic or porphyry conglomeratic layers are present.

The dolostones are similar to the limestones described above. Coarse crystalline dolostone is present, especially in the upper Davis Formation, where it is sometimes medium to pale gray or green whiterock. Some gray mottling is present. The dolo- 


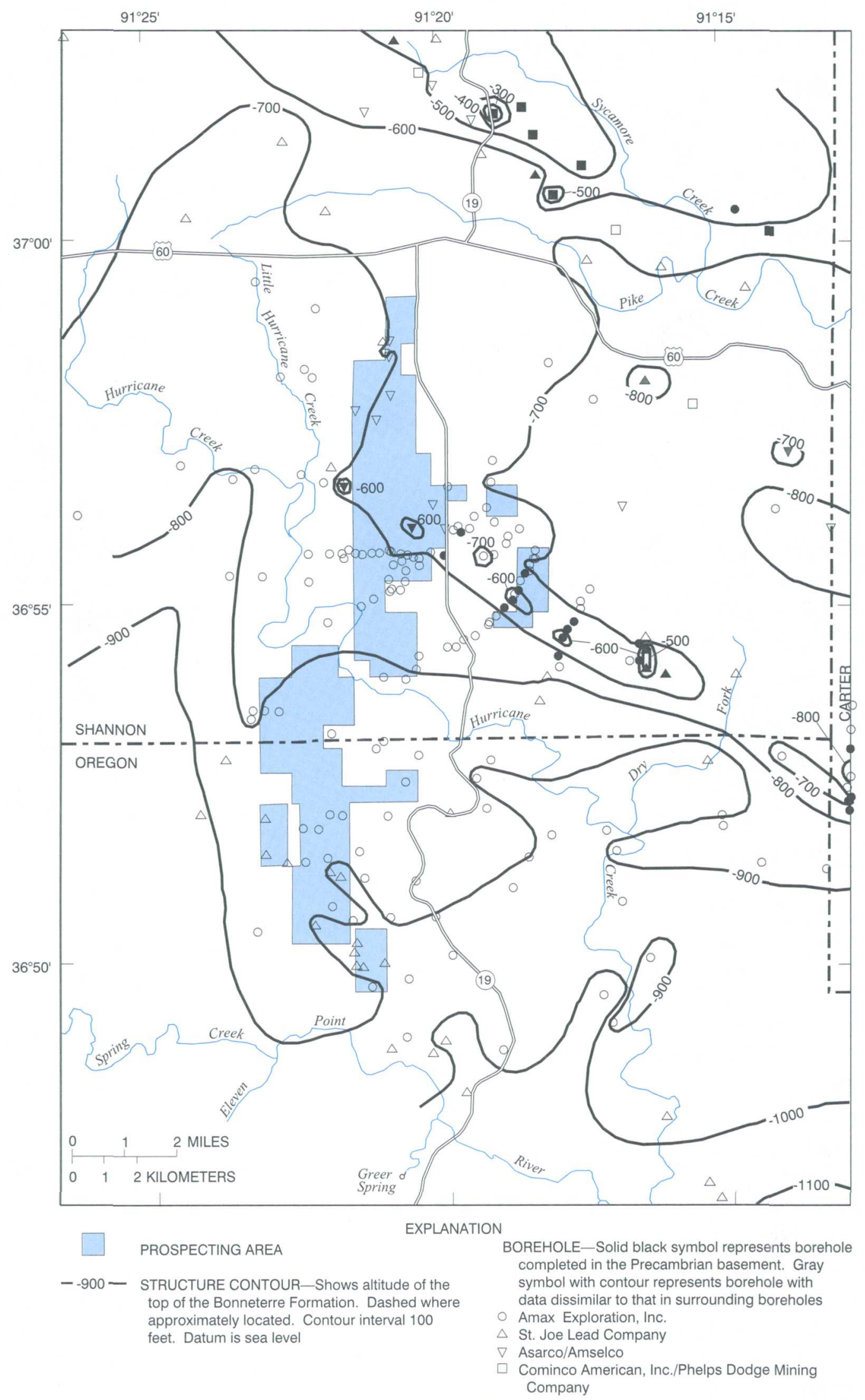

Figure 8. Structure of the top of the Bonneterre Formation. 
stone has more vugs and is more porous than the limestone; vugs are partially occluded by calcite and dolomite. Core descriptions report limonite coatings in vugs in the upper part of the Davis Formation; this coating probably is a very ferroan (containing ferrous iron) dolomite.

Based on 227 data points, the depth from land surface to the top of the Davis Formation ranges from 1,171 to 1,692 feet and the altitude of the top of the formation ranges from 200 feet below sea level (borehole 212 ) to 878 feet below sea level (borehole $229,0.6$ mile south of the study area) (table 1, figs. 6 and 9). The structure map is similar to that of the top of the Bonneterre Formation with the presence of the two structural highs in the study area and the general dip of the formation to the south.

\section{Derby-Doerun Dolomite}

The Derby-Doerun Dolomite is composed of light gray to gray or light tan to brown mudstones, grainstones, and mudstone-matrix boundstones, with some wackestones and wackestone-matrix boundstones. Dolostones are fine to coarse crystalline and fine- to medium-grained. Whiterock is scattered throughout and some mottling was reported. Bedding is thin to massive; thin disturbed beds may be burrowed. The dolostones contain fossil fragments (type not specified), oolites, and carbonate lithic clasts. Digitate stromatolites and crypt-algal laminates are present. Occasional scattered porphyry clasts are present. Thin black to dark gray and green shales are scattered throughout; shale content and bed thickness increases near the contact with the Davis Formation.

Glauconite is present near the base, where dolostones are interbedded with shales. Dolostones vary in visible porosity from none to extremely vuggy. Unlike the overlying Potosi Dolomite, the Derby-Doerun Dolomite contains only minor chalcedony and quartz vug linings. Highly fractured zones are present, although not ubiquitous; some fractures are healed by dolomite and calcite. Breccias are present, but are in part healed by the same cements. Some fractures have minor to abundant iron oxide staining on the fracture surface. Many mining companies did not begin coring until they had already penetrated the Derby-Doerun Dolomite; consequently, complete core intervals of the Derby-Doerun Dolomite are not equally distributed.
The Derby-Doerun Dolomite is the uppermost formation mapped during this study. Based on the data from 212 control points, the depth from land surface to the top of this formation ranges from 970 to 1,598 feet, and the altitude of the top of the formation ranges from 18 feet above sea level (borehole 221, 1.5 miles north of the study area) to 788 feet below sea level (borehole 229, table 1, figs. 6 and 10). The Derby-Doerun Dolomite structure map is similar to that of the Davis Formation with the two structural highs in the study area and the general slope of the formations to the south.

The St. Francois confining unit thickness as determined by core logs ranges from 173 to 656 feet (table 1; fig. 11) in the study area. Most boreholes in which the confining unit was logged at more than 400 feet thick had abnormally thick Derby-Doerun Dolomite sequences. Eight boreholes [boreholes 162, 199, $216,218,219$, and 230 (fig. 6) are shown on figure 11 ; boreholes 221 and 236 (fig. 6) were slightly outside the study area boundary] were logged with abnormally thick confining unit sequences. This may have been a result of different criteria being used to define the Potosi and Derby-Doerun Dolomites and consequently part of the Potosi Dolomite near the conformable contact may have been logged as Derby-Doerun Dolomite. Typically the confining unit has a thickness ranging from 250 to 375 feet thick (table 1; fig. 11) in the study area.

The net shale thickness of the St. Francois confining unit also was mapped (table 1, fig. 12). The thickness ranged from less than 50 feet in the northeastern part of the study area to more than 150 feet in the southwest. This is consistent with the current understanding of the environment at the time these formations were deposited. The deeper part of the basin would have been to the west of the prospecting area. This would have been a low-energy setting allowing the deposition of the silts and clays and the formation of shale deposits.

These conclusions are consistent with Fletcher (1974) who states that the clastic (includes sand and shales)-to-carbonate ratio in the Davis Formation increases westward from the presently exposed Precambrian highlands in the St. Francois Mountains east of the Viburnum Trend (fig. 1). Thacker and Anderson (1979) also show the clastic-to-carbonate ratio in the Davis Formation increasing to the west of buried Precambrian knobs identified by Fletcher (1974) in the Viburnum Trend. The decrease in thickness and clastic/ carbonate composition of the Davis Formation can 


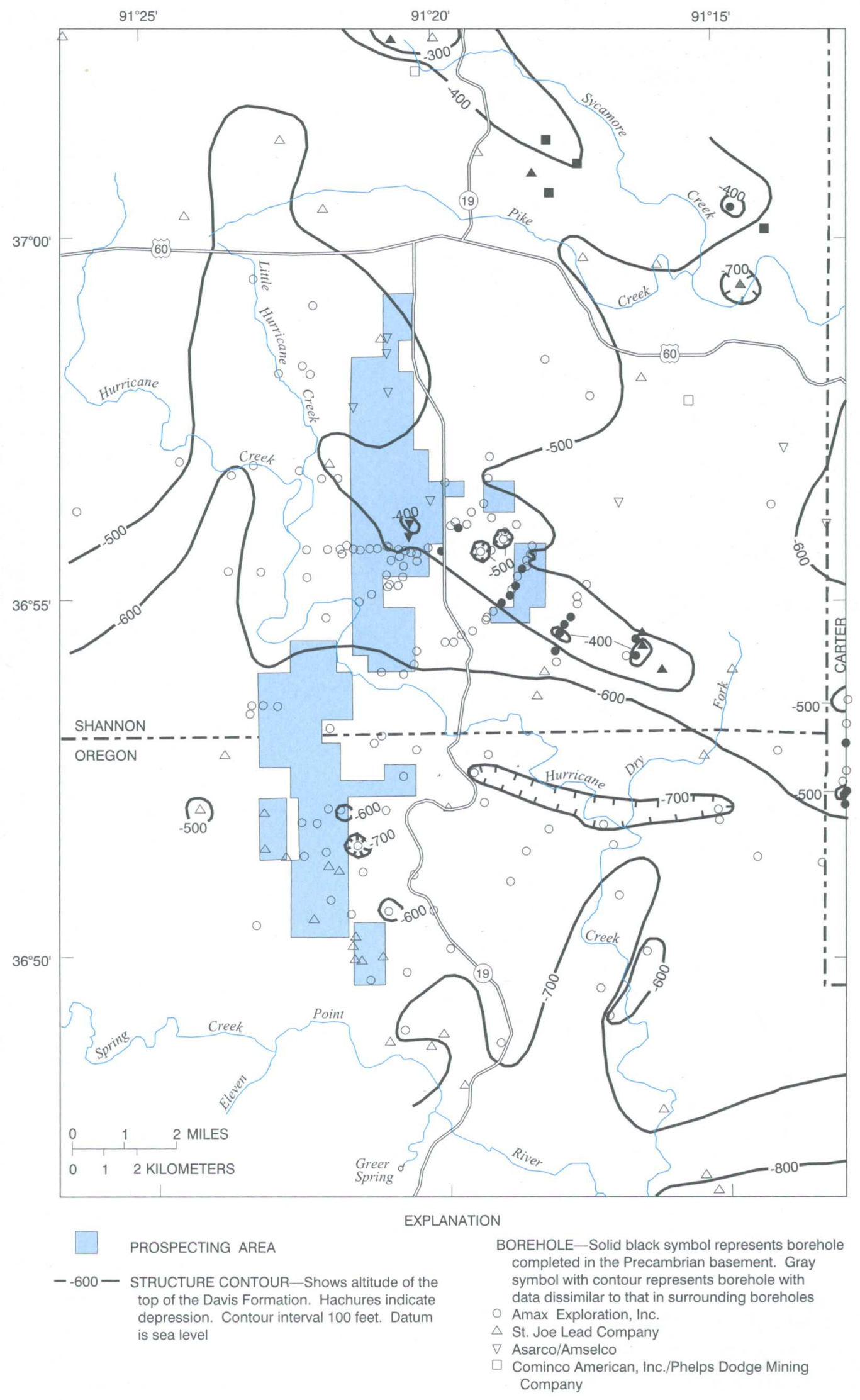

Figure 9. Structure of the top of the Davis Formation. 


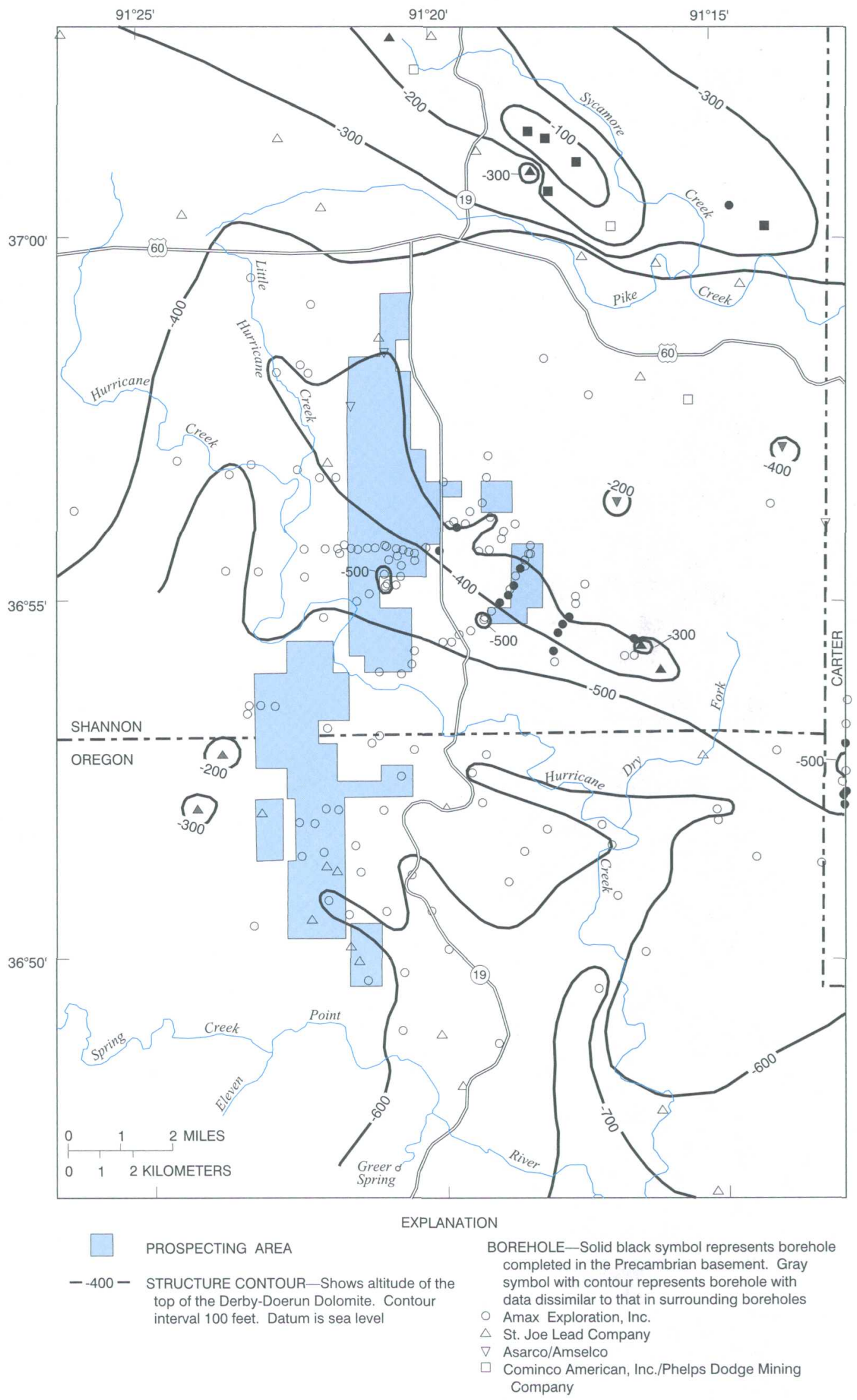

Figure 10. Structure of the top of the Derby-Doerun Dolomite. 


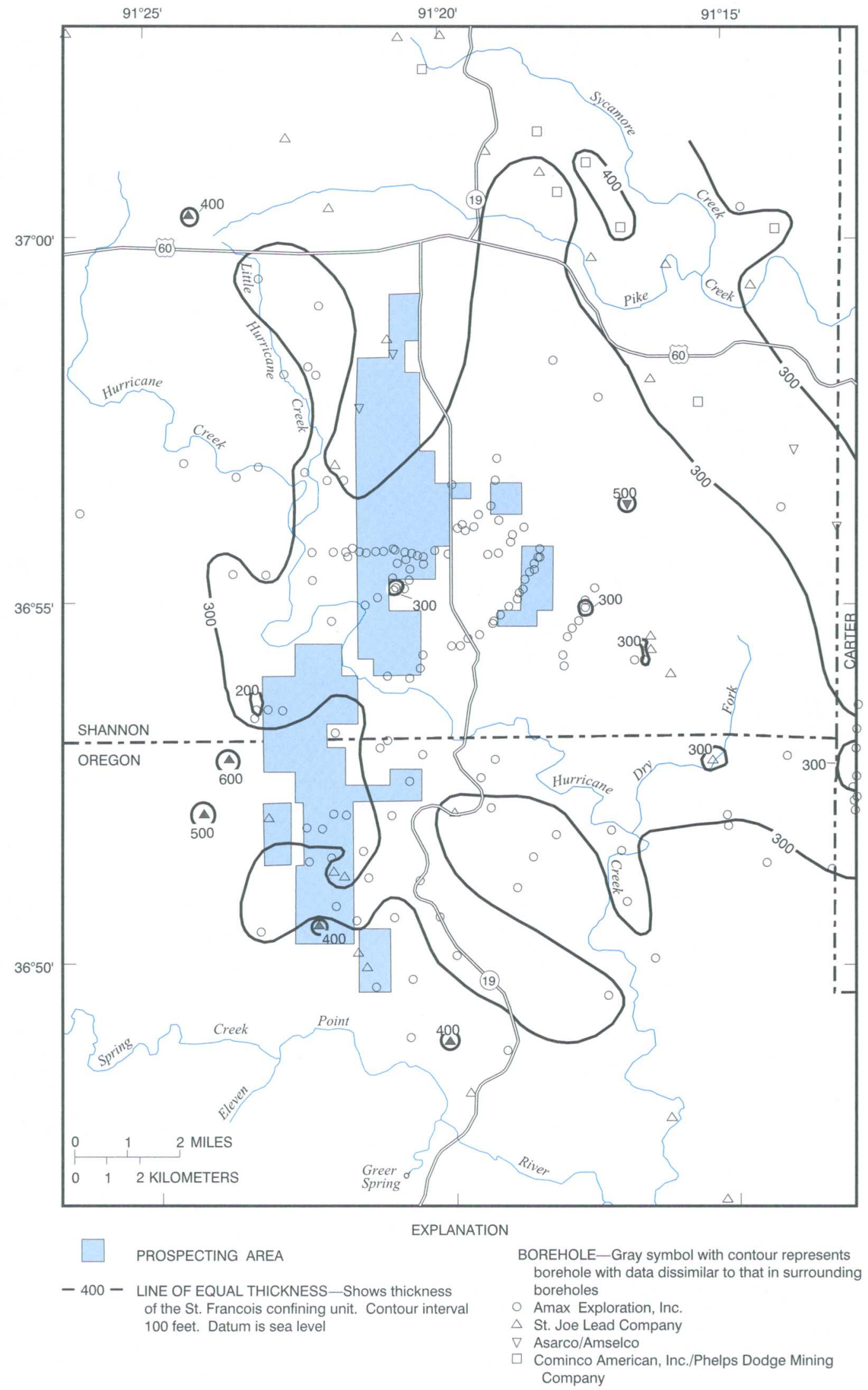

Figure 11. Thickness of the St. Francois confining unit. 


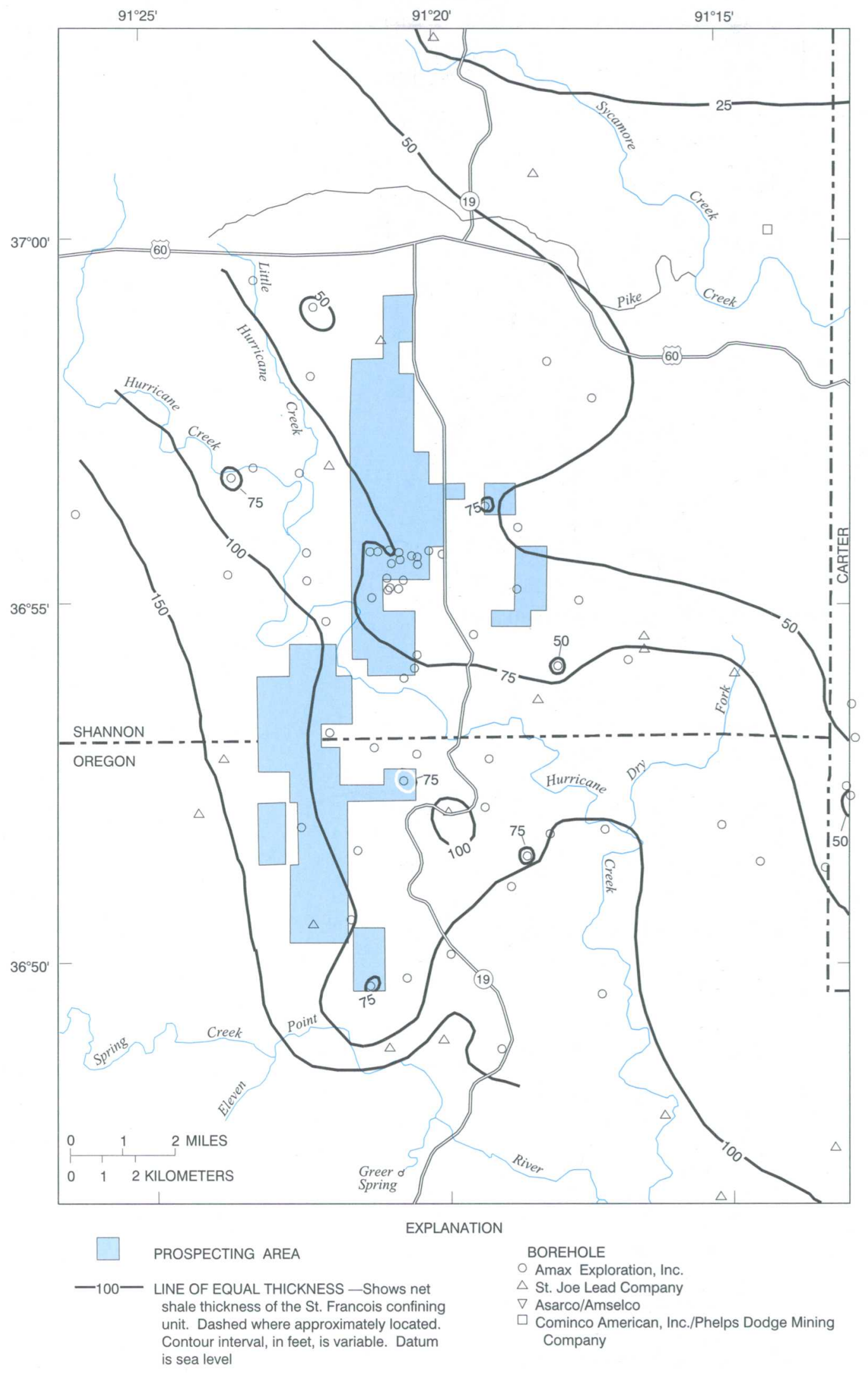

Figure 12. Net shale thickness of the St. Francois confining unit. 
rieduce the ability of the confining unit to impede flow between the Ozark and St. Francois aquifers near the Precambrian knobs.

\section{VERTICAL HYDRAULIC CONDUCTIVITY}

Laboratory testing was used to determine the vertical hydraulic conductivity and porosity of various rock types present in the St. Francois confining unit. Shale typically has a smaller permeability than carbonate rocks (Freeze and Cherry, 1979). By determining the thickness of the confining unit, the net shale thickness of the unit, and the vertical hydraulic conductivity range of the various rock types present in the unit, the data are available to quantitatively estimate the confining ability of the unit. Permeability is a function of the medium (rock core) alone and is not dependent on the fluid used or the force field causing the movement of the liquid (Lohman and others, 1972). Hydraulic conductivity is a measure of the ease with which a specific fluid can be transmitted through a porous medium, and is a function of the medium and of the density and viscosity of the fluid being transmitted. The transmitted fluid used during the permeability tests was similar to water that flows through the confining unit in the study area. This allowed representative vertical hydraulic conductivities to be determined from laboratory core permeability results.

Rock cores from both the study area and the Viburnum Trend were sent to the Core Petrophysics, Inc. laboratory in Houston, Texas, for vertical hydraulic conductivity analysis. Samples from the Viburnum Trend were collected and analyzed for comparison with the results of the core analyzed from the study area. The potential lead-zinc deposits in the prospecting area probably have formed in a similar geologic depositional environment and by the same processes that formed the deposits that are currently (2000) being mined in the Viburnum Trend. The vertical hydraulic conductivity of the confining unit in the Viburnum Trend is minimal, allowing effective dewatering and mining. A comparison of the vertical hydraulic conductivity of the confining units in the two areas can give insight as to the potential of the confining unit in the prospecting area to inhibit ground-water flow between aquifers.

Rock core samples that represent the entire St. Francois confining unit sequence were selected and sent to the laboratory for analysis. Sixty-four core samples were selected from 11 boreholes in the Fristoe Unit and 24 samples were selected from 5 boreholes in the southern part of the Viburnum Trend (table 2, at the back of this report). Twenty-six core samples were from the Derby-Doerun Dolomite and 59 samples were from the Davis Formation. One sample (sample number 35, table 2) was logged as the Derby-Doerun Dolomite, but after further inspection, the core was determined to probably be from the lower Potosi Dolomite; two samples (sample numbers 6 and 29, table 2) after further inspection were determined to be from the upper Bonneterre Formation.

\section{Methodology}

Vertical permeability and porosity were determined in the laboratory for the rock core samples using methods described by the American Petroleum Institute (1998). The test conditions simulated the in situ conditions at the depth from which each core sample was collected. The permeability of a medium is inversely proportional to the net confining stresses to which the medium is subjected. A net confining stress [calculated using a pressure gradient of 0.758 pounds per square inch (psi) per foot depth] was applied to each core sample during the permeability analysis (Jim Seale, Core Petrophysics, Inc., written commun., 1999). A water sample collected from the city of Viburnum public-water supply, which pumps water from an abandoned lead mine in the Bonneterre Formation about 50 miles north of the study area was sent with the core samples to the laboratory. The transmitting fluid used in the laboratory vertical permeability analysis had similar density and viscosity properties as the water sample from Viburnum; this allowed the laboratory-derived vertical permeability to be converted to vertical hydraulic conductivity.

The following procedure was used to prepare each core sample at the laboratory. Upon receiving the 88 core samples, the cores were trimmed to right-angle cylinders using air as the bit lubricant. The samples then were extracted with methanol to remove any precipitated salt, then oven dried for 24 hours at a temperature of 240 degrees Fahrenheit. The bulk volumes of the cores were determined by fluid displacement (Archimedes' principle). Dry weights were recorded and the grain densities calculated. Helium porosity of the rock core at room conditions was obtained by measuring a grain volume using Boyle's Law (Jim Seale, Core Petrophysics, Inc., written commun., 1999). 
The core samples were evacuated and pressure saturated at 1,000 psi with the simulated Viburnum water. Saturations were verified gravimetrically upon removal from the saturation cell. The core samples were then placed in individual coreholders and the calculated net confining stress was applied. The differential flow pressure, time, and water volumes produced were recorded. When the permeability was below the reporting limit, the test was allowed to conclude after 48 hours. The effective vertical permeability of the rock core was calculated using the following equation (Jim Seale, Core Petrophysics, Inc., written commun., 1999):

$$
k=\frac{Q \mu L}{A(P u-P d)}
$$

$\mathrm{k}=$ effective permeability, in darcies $(1$ darcy $=$ $9.87 \times 10^{-9}$ centimeters squared)

$\mathrm{Q}=$ flow rate, in cubic centimeters per second

$\mu=$ fluid viscosity, in centipoise $(1$ centipoise $=$ 0.01 gram per centimeter-second)

$\mathrm{L}=$ length, in centimeters

$\mathrm{A}=$ area, in square centimeters

$\mathrm{Pu}=$ upgradient pressure, in atmospheres

$\mathrm{Pd}=$ downgradient pressure, in atmospheres

Hydraulic conductivity is related to permeability by (American Petroleum Institute, 1998):

$$
K=\frac{k \rho g}{\mu}
$$

$\mathrm{K}=$ hydraulic conductivity, in centimeters per second

$\mathrm{k}=$ effective permeability, in darcies

$\rho=$ mass density of the fluid, in grams per cubic centimeters

$\mathrm{g}=$ acceleration of gravity, in centimeters per second squared

$\mu=$ fluid viscosity, in centipoise

After substitution, the conversion of vertical permeability in darcies to vertical hydraulic conductivity in foot per second $(\mathrm{ft} / \mathrm{s})$ becomes:

$$
K=(3.17) \times 10^{-5} k
$$

\section{Evaluation of Results}

Vertical hydraulic conductivities ranged from 8.70 $x 10^{-8} \mathrm{ft} / \mathrm{s}$ for one sample to less than $3.17 \times 10^{-14} \mathrm{ft} / \mathrm{s}$ (the reporting limit) for 39 samples (table 2 ). The porosity values ranged from a high of 17.47 percent to a low of
0.36 percent. There did not appear to be a strong correlation between the vertical hydraulic conductivity and porosity.

With the outliers, the reported vertical hydraulic conductivity values span six orders of magnitude; this, compounded with the large number of values below the reporting limit, cause the mean and standard deviation statistic values for this data set to be strongly distorted. Therefore, box plots (fig. 13) using logarithmic scales are used to present the results.

Figure 13 shows the variation in vertical hydraulic conductivity of different formations and different rock types within the Fristoe Unit (A and C) and the Viburnum Trend (B and D). The variation in vertical hydraulic conductivity between similar formations and rock types in the Fristoe Unit and the Viburnum Trend is also shown on figure $13(\mathrm{E}-\mathrm{J})$.

The Lilliefors (two-tailed) test for normality (Iman and Conover, 1983) showed the vertical hydraulic conductivity data are not normally distributed. Because these data are not normally distributed, the data were ranked. All of the statistical analysis used to evaluate the significant differences between data sets were performed on the ranked data. The WilcoxonMann-Whitney rank sum test (two-tailed) was used when comparing two data sets and an analysis of variance was used to perform multiple-comparisons when more than two data sets were evaluated (Iman and Conover, 1983).

In all of the statistical analysis, a level of significance ( $\alpha$-value) of 0.05 was used to test the null hypothesis which states, the vertical hydraulic conductivity of the data sets being compared are equal. The attained significance level ( $p$-value) is a probability value determined by the data (Iman and Conover, 1983). The null hypothesis was rejected for all analysis with $\mathrm{p}$-values for the pooled data that were less than 0.05 .

No significant difference ( $\mathrm{p}$-value $=0.375$ ) exists between the ranked vertical hydraulic conductivity of samples collected from the Derby-Doerun Dolomite and Davis Formation in the Fristoe Unit. The similarity is also visually expressed (fig. 13A), by the considerable overlap of the two boxplots and the similarity of the median values of the two data sets. However, the interquartile range (the range between the upper and lower quartiles) of vertical hydraulic conductivity shown for the Derby-Doerun Dolomite samples has more than an order of magnitude greater span than the interquartile range shown for the Davis Forma- 


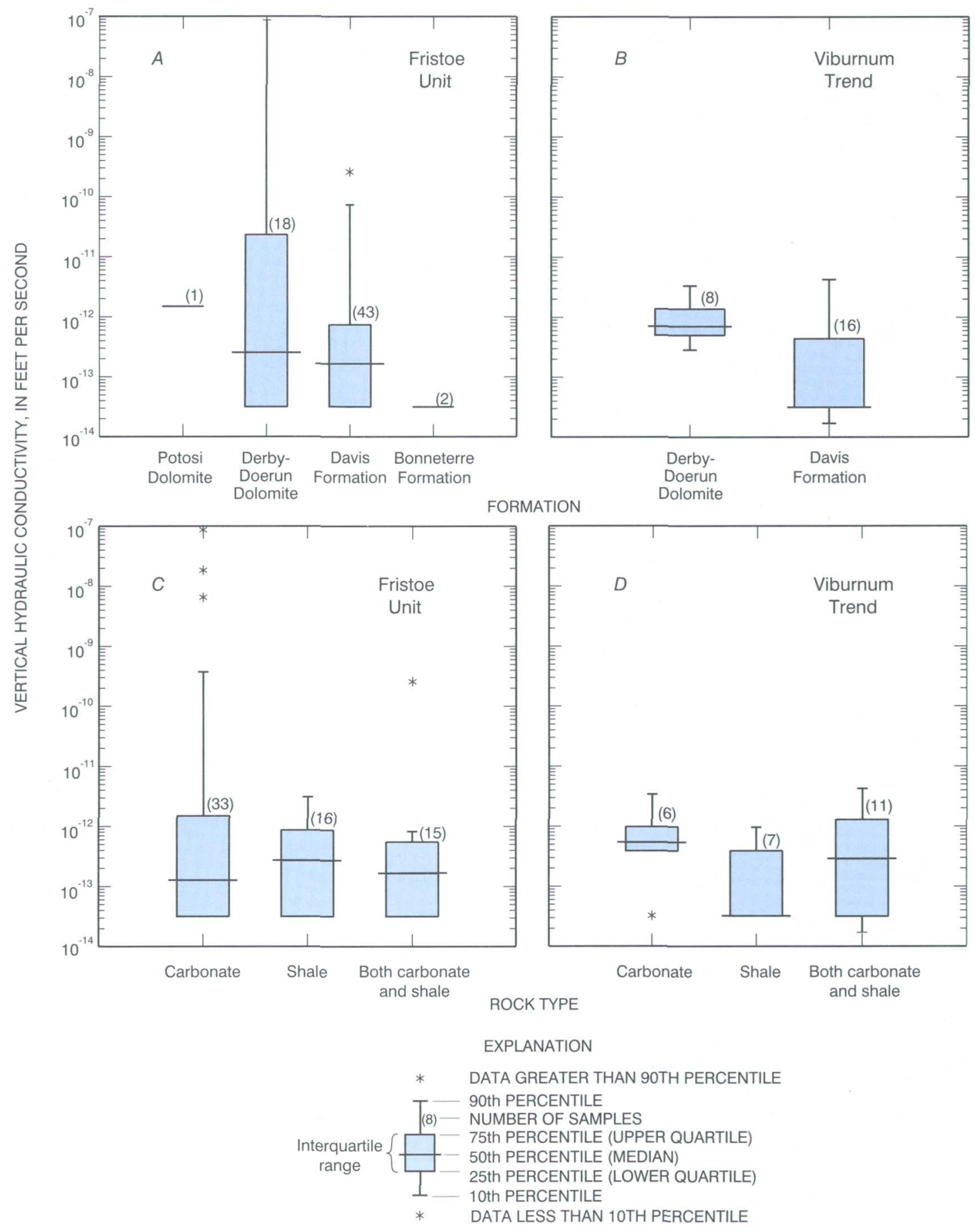

Figure 13. Boxplots showing the vertical hydraulic conductivities of formations and rock types in the Fristoe Unit and Viburnum Trend. 

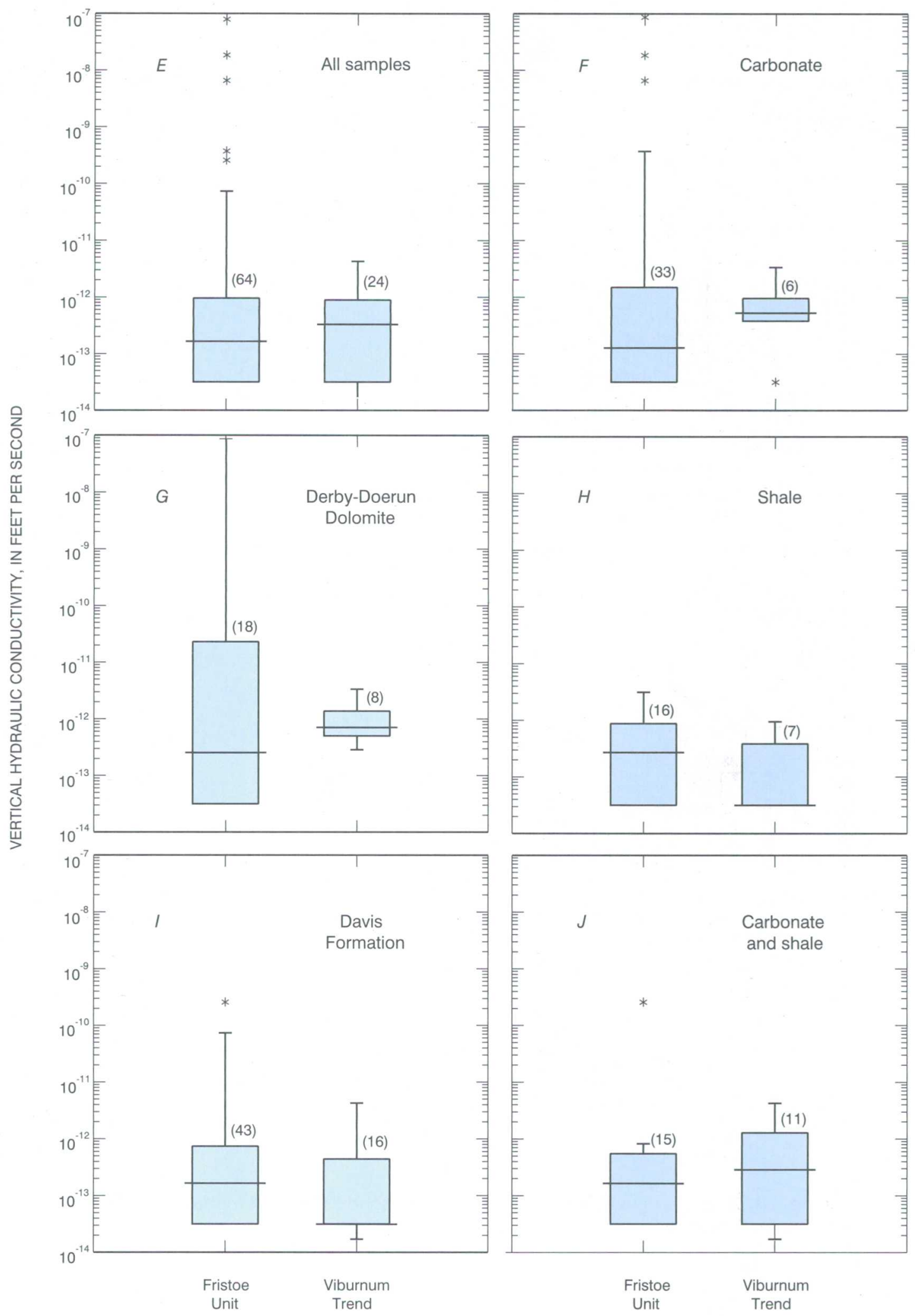

Figure 13. Boxplots showing the vertical hydraulic conductivities of formations and rock types in the Fristoe Unit and Viburnum Trend-Continued. 
tion samples. The samples collected from the Potosi Dolomite and the Bonneterre Formation are shown for comparison purposes, although they are of no importance in evaluating the St. Francois confining unit. The samples from the upper Bonneterre Formation have a low vertical hydraulic conductivity, possibly related to the transitional nature of the contact between the Davis Formation and the Bonneterre Formation.

In the Viburnum Trend, there is a statistically significant difference ( $p$-value $=0.006$ ) between the ranked vertical hydraulic conductivity of the DerbyDoerun Dolomite and the Davis Formation. Although the vertical hydraulic conductivity of both formations is small, the median vertical hydraulic conductivity of the Derby-Doerun Dolomite is more than an order of magnitude greater than the median vertical hydraulic conductivity of the Davis Formation (fig. 13B).

In the Fristoe Unit, there is no statistically significant ( $p$-value $=0.790$ ) vertical hydraulic conductivity difference in ranked samples containing carbonate or shale, or both rock types. This is shown visually (fig. 13C) by the interquartile range of the box plots having considerable overlap and the median values being similar.

In the Viburnum Trend, there is no statistically significant ( $\mathrm{p}$-value $=0.412$ ) vertical hydraulic conductivity difference in ranked samples containing carbonate or shale, or both rock types. Visually (fig. 13D), the carbonate rocks have more than an order of magnitude greater median vertical hydraulic conductivity than shales. The Derby-Doerun Dolomite contains primarily carbonate rocks and the Davis Formation contains primarily shale, this relation is also observed in the Viburnum Trend formation vertical hydraulic conductivity comparisons (fig. 13B). Also, samples from the Viburnum Trend that contain both carbonate and shale have a larger vertical hydraulic conductivity variability than samples from either individual rock type. Samples containing both rock types span the same vertical hydraulic conductivity range as the carbonate and shale together.

The interquartile range of vertical hydraulic conductivity for individual formations and rock types in the Fristoe Unit was compared with those in the Viburnum Trend. A larger variability of some core samples from the Fristoe Unit was observed (fig. 13, F-I). The cause of this variability can be attributed to the carbonate rock samples from the Derby-Doerun Dolomite, which have more than two orders of magnitude greater range in vertical hydraulic conductivity than the
Derby-Doerun Dolomite in the Viburnum Trend. In spite of this variability, the vertical hydraulic conductivity of rock samples from the Fristoe Unit are similar to those from the Viburnum Trend.

One conclusion that can be drawn from the vertical hydraulic conductivity measurements on different rock types in the Fristoe Unit (fig. 13C) is that the net shale thickness is not the single controlling factor that determines the effectiveness of the St. Francois confining unit. Because the vertical hydraulic conductivity of the carbonate rocks and shale in the confining unit are similar, the entire carbonate-shale thickness is important in determining the effectiveness of the confining unit.

Using the results of this study, the range of estimated effective vertical hydraulic conductivity values for the St. Francois confining unit in the Fristoe Unit was calculated. A typical thickness of the confining unit of 300 feet (fig. 11) was used in the calculations. A net shale thickness of 50 feet was used for the minimum effective vertical hydraulic conductivity of the confining unit calculation and 150 feet was used for the maximum (fig. 12). Vertical hydraulic conductivities as represented by the upper and lower quartiles range from about $1 \times 10^{-12}$ to $3 \times 10^{-14} \mathrm{ft} / \mathrm{s}$ for the carbonate rocks and $9 \times 10^{-13}$ to $3 \times 10^{-14} \mathrm{ft} / \mathrm{s}$ for shale in the Fristoe Unit.

The effective vertical hydraulic conductivity of a unit composed of several layers aligned in series, with each layer having different vertical hydraulic conductivities can be calculated using the formula:

$$
\begin{aligned}
\frac{d_{t}}{K_{t}}= & \frac{d_{1}}{K_{1}}+\frac{d_{2}}{K_{2}}+\frac{d_{3}}{K_{3}}+\frac{d_{n}}{K_{n}} \\
\mathrm{~d}_{\mathrm{t}}= & \text { total thickness of the confining unit } \\
\mathrm{d}_{1}, \mathrm{~d}_{2}, \mathrm{~d}_{3}, \mathrm{~d}_{\mathrm{n}}= & \text { thickness of layer } 1 \text {, layer } 2 \text {, layer } \\
& 3 \text {, and layer } \mathrm{n} \\
\mathrm{K}_{\mathrm{t}}= & \text { effective vertical hydraulic } \\
& \text { conductivity of unit } \\
\mathrm{K}_{1}, \mathrm{~K}_{2}, \mathrm{~K}_{3}, \mathrm{~K}_{\mathrm{n}}= & \text { vertical hydraulic conductivity of } \\
& \text { layer 1, layer } 2 \text {, layer } 3 \text {, and layer } \mathrm{n}
\end{aligned}
$$

By using appropriate extreme values of net shale thickness and vertical hydraulic conductivity, the range of effective vertical hydraulic conductivity for the confining unit in the study area was estimated to be a maximum of $1 \times 10^{-12} \mathrm{ft} / \mathrm{s}$ and a minimum of $3 \times 10^{-14} \mathrm{ft} / \mathrm{s}$. These vertical hydraulic conductivity values are small, allowing the confining unit to effectively impede the flow of ground water between the Ozark aquifer and 
the St. Francois aquifer, unless preferred-path secondary permeability has developed along faults and fractures.

\section{SUMMARY AND CONCLUSIONS}

This report assesses the confining ability of the St. Francois confining unit in six townships (T25-27N and R03-04W) of the Fristoe Unit of the Mark Twain National Forest in Oregon and Shannon Counties of southeastern Missouri. This was accomplished by describing the depositional environment and stratigraphy of the St. Francois confining unit, and quantifying the vertical hydraulic conductivity of rock core samples from the confining unit using laboratory techniques. Stratigraphic data for this study were obtained by analysis of 238 exploration borehole core logs and rock core from exploration boreholes that typically described a 600- to 800-foot interval from near the bottom of the Potosi Dolomite into the Lamotte Sandstone or Precambrian basement rock.

The Upper Cambrian sediments are composed of alluvial and fluvial clastics that grade upward into marine sandstones and carbonates and are characteristic of intrashelf basin areas. These sediments were deposited during repeated cycles of marine transgressions and subsequent shallowing. This sedimentation was controlled by pre-Late Cambrian uplift and erosion of the igneous basement rock and by faulting during the Late Cambrian Epoch. Faulting created a Precambrian highland area (St. Francois Mountains) and basins; erosion gave the Precambrian igneous knobs an irregular shape. This erosion and a marine transgression with continued deposition of clastic material led to the accumulation of sediments that formed the Lamotte Sandstone, which is interpreted as a near shore barrier and shallow tidal flat complex. Transgression caused shelf drowning and gradual development of a large intrashelf basin with a narrow, discontinuous rim (lowermost Bonneterre Formation) which allowed the carbonatedominant facies to form. The transition from shaley deposits with a limited stromatolite zone to carbonate with more frequent stromatolites suggest a general shallowing of the sequence as the Bonneterre Formation was deposited. Several rock sequences in the Bonneterre Formation show a cyclic pattern of deepening, then becoming shallow. Retention of limestone in the basal part of the Bonneterre Formation suggests that the southern and extreme northwestern parts of the study area were deeper offshore environments.
The Bonneterre Formation-Davis Formation contact denotes abrupt intrashelf basin development that was filled during cycles of transgression and shallowing. The intrashelf basin likely had a wide, continuous shelf rim producing the shale-dominant Davis Formation. Horizontal burrows in the Davis Formation suggest a slow periodic deposition in a marine subtidal setting, where the shelf underwent gradual drowning during a slow transgression. The Derby-Doerun Dolomite was formed during a pair of carbonate depositional cycles. The basal shaley sequence represents a transition with the Davis Formation.

Arkosic and porphyry conglomeratic material throughout the section indicates Precambrian highlands remained exposed during Upper Cambrian carbonate deposition. Continued exposure of the Precambrian highlands may have been caused by the original height of the highlands, or be the result of continued uplift on fault-related structures.

Thirty-three exploration holes penetrated Precambrian knobs. These boreholes appear to intercept two linear structures or ridges that trend northwestsoutheast. These knobs generally protrude less than 200 feet above the surrounding Precambrian basement rock; however, some knobs along both of these ridges extend more than 500 feet above the surrounding basement rock. Structural evidence of the Precambrian knobs or ridge in the central part of the study area appears to extend as high as the Roubidoux Formation.

The Lamotte Sandstone is present throughout the study area, except where it pinches out against some Precambrian knobs. The greatest thicknesses of this formation indicated by borehole data are 50 to 60 feet. The depth from land surface to the top of the Lamotte Sandstone, where present, ranges from 1,552 to 2,450 feet with an altitude ranging from a high of 502 feet below sea level to a low of 1,600 feet below sea level. The general dip of the formation is to the south or southeast. Both of the Precambrian ridges can be identified as prominent structural high features or domes. A structural high is evident in the southeastern part of the study area and is adjacent to a structural trough that trends to the south. This trough is also a distinct feature on structural maps of overlying formations.

The lower Bonneterre Formation is subdivided into a basal part composed of carbonate with interbedded shale and an upper part composed of dolostone with occasional shale layers or partings. Algal structures present in the basal part are digitate stromatolites as much as 1 foot high, occasional crypt-algal lami- 
nates, and minor hummocky algal forms. Grains are oolites and fossil fragments (type not specified). The upper part of the lower Bonneterre Formation is composed of interbedded dolostone grainstones, mudstones, and grainstone- and mudstone-matrix boundstones, with occasional wackestones. Algal reef zones in this upper part are also common and are welldefined digitate stromatolites with infrequent hummocky algal features; reef zones reach thicknesses of 100 feet. Dark green shale partings are present throughout the Whetstone Creek Member of the upper Bonneterre Formation and a prominent shale ( 1 to 27 feet thick) at the base of unit is informally known as the False Davis.

The depth from land surface to the top of the Bonneterre Formation ranges from 1,358 to 2,002 feet and the altitude of the top of the formation ranges from 278 feet below sea level to 1,152 feet below sea level. The formation generally dips to the south or southeast. Evidence for the two Precambrian ridges in the study area can again be observed as domed features. The trough structure in the southern part of the study area is also evident. The structure map of the top of the Bonneterre Formation indicates problems associated with using core logs from various sources to map formation tops. The fingering effect of the contours in the southern part of the prospecting area may be caused by different criteria used during core logging for identifying the top of the Bonneterre Formation, as opposed to the presence of structural features.

The Davis Formation is composed of interbedded shales and carbonates, with both shale- and carbonate-dominant sequences and ranges from less than 50 to more than 300 feet thick. Shale-dominant sequences can be as thick as 50 feet, and contain as much as 90 percent shale. The Davis Formation carbonates primarily are limestone, with dolostone at the top and base of the formation. The shales restricted the flow of dolomitizing fluids from reaching most Davis Formation limestones.

The depth from land surface to the top of the Davis Formation ranges from 1,171 to 1,692 feet, and the altitude of the top of the formation ranges from 200 feet below sea level to 878 feet below sea level. The structure map is similar to that of the top of the Bonneterre Formation, with the presence of the two linear highs in the study area and the general dip of the formation to the south.
The Derby-Doerun Dolomite is composed of mudstones, grainstones, and mudstone-matrix boundstones. Digitate stromatolites and crypt-algal laminates are present. Thin shales are present throughout but shale content and bed thickness increases near the contact with the Davis Formation.

The depth from land surface to the top of the Derby-Doerun Dolomite (the uppermost formation mapped) ranges from 970 to 1,598 feet and the altitude of the top of the formation ranges from 18 feet above sea level to 788 feet below sea level. The Derby Doerun Dolomite structure map is similar to that of the Davis Formation with the two structural highs in the study area and the general slope of the formation to the south.

Typically the combined thickness of the DerbyDoerun Dolomite and Davis Formation (St. Francois confining unit) ranges from 250 to 375 feet thick in the study area; however, the confining unit was logged at more than 400 feet thick for several boreholes. Most of these boreholes had abnormally thick Derby-Doerun Dolomite sequences. This may have been a result of the Potosi Dolomite near the conformable contact with the Derby-Doerun Dolomite being logged as DerbyDoerun Dolomite. The net shale thickness of the St. Francois confining unit ranges from less than 50 feet in the northeast part of the study area to more than 150 feet in the southwest.

Laboratory vertical hydraulic conductivity and porosity analysis were performed on 88 core samples primarily representing the various rock types present in the St. Francois confining unit of the Fristoe Unit and the Viburnum Trend area. The vertical permeability values were converted to vertical hydraulic conductivity. Vertical hydraulic conductivity ranged from $8.70 \mathrm{x}$ $10^{-8}$ foot per second for one sample to less than $3.17 \mathrm{x}$ $10^{-14}$ foot per second (the reporting limit) for 39 samples. The porosity values ranged from a high of 17.47 percent to a low of 0.36 percent. There did not appear to be a strong correlation between vertical hydraulic conductivity and porosity.

There is no significant difference ( $\mathrm{p}$-value $=$ 0.375 ) between the ranked vertical hydraulic conductivity of samples collected from the Derby-Doerun Dolomite and Davis Formation in the Fristoe Unit. The interquartile range of vertical hydraulic conductivity shown for the Derby-Doerun Dolomite samples has more than an order of magnitude greater span than the interquartile range shown for the Davis Formation samples. 
In the Viburnum Trend, there is a statistically significant difference ( $p$-value $=0.006$ ) between the ranked vertical hydraulic conductivity of the DerbyDoerun Dolomite and the Davis Formation. Although the vertical hydraulic conductivity of both formations is small, the median vertical hydraulic conductivity of the Derby-Doerun Dolomite is more than an order of magnitude greater than the median vertical hydraulic conductivity for the Davis Formation.

In the Fristoe Unit, there is no statistically significant ( $p$-value $=0.790$ ) vertical hydraulic conductivity difference in ranked samples containing carbonate or shale or both rock types. This is also true when comparing ranked samples containing carbonate or shale or both rock types from the Viburnum Trend ( $\mathrm{p}$-value = 0.412 ), even though carbonate rocks have more than an order of magnitude greater median vertical hydraulic conductivity than shales. Also, samples from the Viburnum Trend that contain both carbonate and shale have a larger vertical hydraulic conductivity variability than samples from either individual rock type. Samples containing both rock types span the same vertical hydraulic conductivity range as the carbonate and shale together.

The net shale thickness is not the single controlling factor that determines the effectiveness of the confining unit. Because the vertical hydraulic conductivity of the carbonate rocks and shale in the confining unit are similar, the entire carbonate-shale thickness is important in determining the effectiveness of the confining unit.

The range of estimated effective vertical hydraulic conductivity for the St. Francois confining unit in the study area was calculated using the results of this study. The calculations used 300 feet as the typical thickness of the confining unit; 50 and 150 feet as the lower and upper net shale thickness ranges; $1 \times 10^{-12}$ to $3 \times 10^{-14}$ foot per second as the upper and lower vertical hydraulic conductivity range (upper and lower quartiles) of the carbonate rock; and $9 \times 10^{-13}$ to $3 \mathrm{x}$ $10^{-14}$ foot per second as the upper and lower vertical hydraulic conductivity range (upper and lower quartiles) of the shale. Resulting estimates of effective vertical hydraulic conductivity were calculated to be a maximum of $1 \times 10^{-12}$ foot per second and a minimum of $3 \times 10^{-14}$ foot per second. These vertical hydraulic conductivity values are small, allowing the confining unit to effectively impede the flow of ground water between the Ozark aquifer and the St. Francois aquifer, unless preferred-path secondary permeability has developed along faults and fractures.

\section{REFERENCES CITED}

American Petroleum Institute, 1998, Recommended practices for core analysis: Washington, D. C. American Petroleum Institute, 195 p.

Dunham, R.J., 1962, Classification of carbonate rocks according to depositional texture, in Ham, W.E. ed., Classification of Carbonate Rocks-a Symposium, Tulsa, Oklahoma: American Association of Petroleum Geologists Memoir 1, p. 108-121.

Fletcher, C.S., 1974, The geology and hydrogeology of the New Lead Belt, Missouri: University of Missouri-Rolla, unpublished M.S. thesis, $91 \mathrm{p}$.

Folk, R.L., 1959, Practical petrographic classification of limestones: American Association of Petroleum Geologists Bulletin, v. 43, p. 1-38.

Freeze, R.A., and Cherry, J.A., 1979, Groundwater: Prentice-Hall, Inc., Englewood Cliffs, New Jersey, $604 \mathrm{p}$.

Hauck, H.S., Huber, L.G., and Nagel, C.D., 1997, Water resources data Missouri water year 1996: U.S. Geological Survey Water-Data Report MO96-1, $292 \mathrm{p}$.

1999, Water resources data Missouri water year 1998: U.S. Geological Survey Water-Data Report MO-98-1, $434 \mathrm{p}$.

Hayes, W.C., and Knight, R.D., 1961, Cambrian System, in Koenig, J.W., ed., revised 1995, Thompson, T.L., ed., Stratigraphic Succession in Missouri: Missouri Geological and Water Resources, v. 40, second series, p. 14-20.

Houseknecht, D.W., and Ethridge, F.G., 1978, Depositional history of the Lamotte Sandstone of southeastern Missouri: Journal of Sedimentary Petrology, v. 48, no. 2, p. 575-586.

Howe, W.B., 1968, Planar stromatolite and burrowed carbonate mud facies in Cambrian strata of the St. Francois Mountain area: Missouri Geological Survey and Water Resources Report of Investigations No. 41,113 p.

Imes, J.L., 1989, Major geohydrologic units in and adjacent to the Ozark Plateaus province, Missouri, Arkansas, Kansas, and Oklahoma-Basement confining unit: U.S. Geological Survey Hydrologic Investigations Atlas HA-711-B, 1 sheet. 
Imes, J.L., 1990a, Major geohydrologic units in and adjacent to the Ozark Plateaus province, Missouri, Arkansas, Kansas, and Oklahoma-Ozark aquifer: U.S. Geological Survey Hydrologic Investigations Atlas HA-711-E, 3 sheets.

-1990b, Major geohydrologic units in and adjacent to the Ozark Plateaus province, Missouri, Arkansas, Kansas, and Oklahoma-St. Francois confining unit: U.S. Geological Survey Hydrologic Investigations Atlas HA-711-D, 3 sheets. -1990c, Major geohydrologic units in and adjacent to the Ozark Plateaus province, Missouri, Arkansas, Kansas, and Oklahoma-St. Francois aquifer: U.S. Geological Survey Hydrologic Investigations Atlas HA-711-C, 2 sheets.

Imes, J.L., and Emmett, L.F., 1994, Geohydrology of the Ozark Plateaus aquifer system in parts of Missouri, Arkansas, Oklahoma, and Kansas: U.S. Geological Survey Professional Paper 1414-D, $127 \mathrm{p}$.

Imes, J.L., and Kleeschulte, M.J., 1995, Seasonal ground-water level changes (1990-93) and flow patterns in the Fristoe Unit of the Mark Twain National Forest, southern Missouri: U.S. Geological Survey Water-Resources Investigations Report 95-4096, 1 sheet.

Iman, R.L., and Conover, W.J., 1983, A modern approach to statistics: John Wiley and Sons, New York, New York, 497 p.

Kleeschulte, M.J., and Sutley, S.J., 1995, Hydrologic data for the Fristoe Unit of the Mark Twain National Forest, Southern Missouri, 1988-1993: U.S. Geological Survey Open-File Report 95-106, $106 \mathrm{p}$.

Larsen, K.G., 1975, Stratigraphic and facies nomenclature of the Viburnum Trend, southeast Missouri, in Vineyard, J.D. ed., Guidebook to the geology and ore deposits of selected mines in the Viburnum Trend, Missouri: Rolla, Missouri Division of Geology and Land Survey, Report of Investigations 58, p. 15-19.

1977, Sedimentology of the Bonneterre Formation, southeast Missouri: Economic Geology, v. 72, p. 408-419.

Lohman, S.W., and others, 1972, Definitions of selected ground-water terms-Revisions and conceptual refinements: U.S. Geological Survey Water-Supply Paper 1988, 21 p.

Lyle, J.R., 1977, Petrography and carbonate diagenesis of the Bonneterre Formation in the Viburnum
Trend area, southeast Missouri: Economic Geology, v. 72 , p. $420-434$.

Palmer, J.R., 1989, Late Upper Cambrian shelf depositional facies and history, southern Missouri, in Gregg, Jay M., Palmer, James R., and Kurtz, Vincent E., eds., Field guide to the Upper Cambrian of southeastern Missouri: stratigraphy, sedimentology, and economic geology: Department of Geology and Geophysics, University of Missouri at Rolla, p. 1-24.

Palmer, J.R., 1991a, Distribution of lithofacies and inferred depositional environments in the Cambrian System, in Martin, J.A., and Pratt, W.P., eds., Geology and mineral-resource assessment of the Springfield $1^{\circ} \times 2^{\circ}$ quadrangle, Missouri, as appraised in September 1985: U. S. Geological Survey Bulletin 1942, 115 p.

1991b, Stratigraphy and porosity characteristics, uppermost Lamotte Sandstone, Bonneterre Formation, and basal Davis Formation, in two closely spaced drillcores; Greer 7.5 minute quadrangle, Oregon County, Missouri: Unpublished report, Missouri Department of Natural Resources, Division of Geology and Land Survey, $16 \mathrm{p}$.

Palmer, J.R., and Seeger, C.M., 1998, Synsedimentary tectonic features in southeast Missouri, in Seeger, C.M. ed., Syndepositional tectonics during the Late Upper Cambrian: Association of Missouri Geologists 45th Annual Meeting and Field Trip, September 25-26, 1998, Farmington, Missouri: p. 27-48.

Thacker, J.L., and Anderson, K.H., 1979, Preliminary carbonate lithofacies maps of the Cambrian Davis Formation, Rolla $1^{\circ} \times 2^{\circ}$ quadrangle, Missouri 1:250,000: Rolla, Missouri, Division of Geology and Land Survey, 2 sheets.

U.S. Department of Agriculture, Forest Service, and U.S. Department of the Interior, Bureau of Land Management, 1987, Environmental Analysis Doe Run Exploratory Drilling Project: Rolla, Missouri, U.S. Department of Agriculture, $98 \mathrm{p}$.

U.S. Department of Agriculture, Forest Service, and U.S. Department of the Interior, Bureau of Land Management, 1988, Final Environmental Impact Statement, Hardrock Mineral Leasing Mark Twain National Forest: Rolla, Missouri, U.S. Department of Agriculture, $129 \mathrm{p}$. with appendices.

U.S. Department of Agriculture, Forest Service, and U.S. Department of the Interior, Bureau of Land 
Management, 1991, Environmental analysis Doe Run Exploratory Drilling Project, Bureau of Land Management permits ES 19219 and ES 19220:

Rolla, Missouri, U.S. Department of Agriculture, 70 p. with appendices.

Wharton, H.M., 1975, Introduction to the southeast Missouri lead district, in Vineyard, J.D., ed., The geology and ore deposits of selected mines, Vibur- num Trend, Missouri: Rolla, Missouri Division of Geology and Land Survey, Report of Investigations 58, p. 3-14.

Yesberger, W.L., 1982, Paleoenvironments and depositional history of the Upper Cambrian Lamotte Sandstone in southeast Missouri: unpublished M.A. thesis, University of Missouri at Columbia, $287 \mathrm{p}$. 
TABLES 


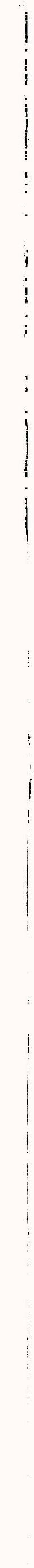

. 


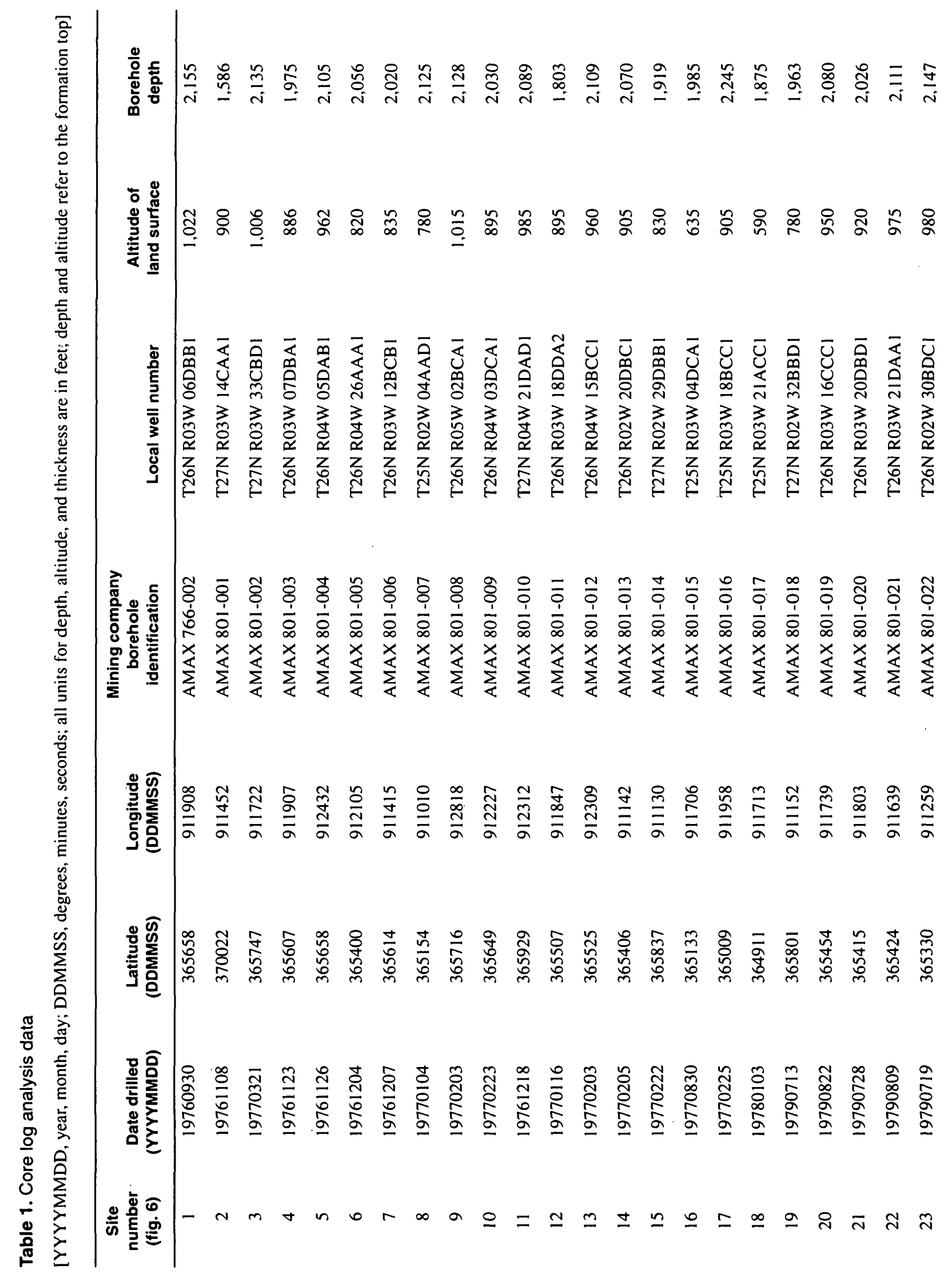




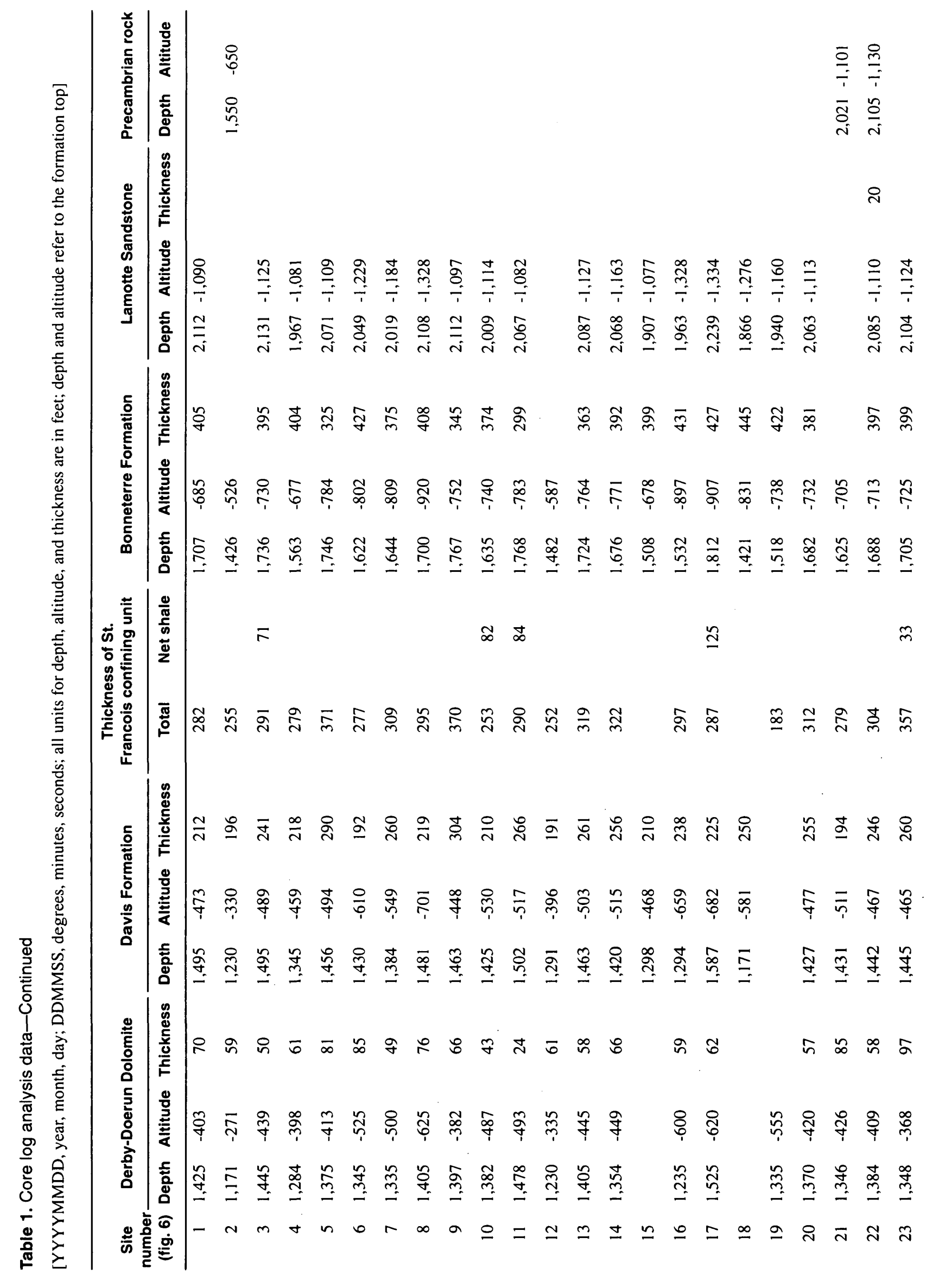




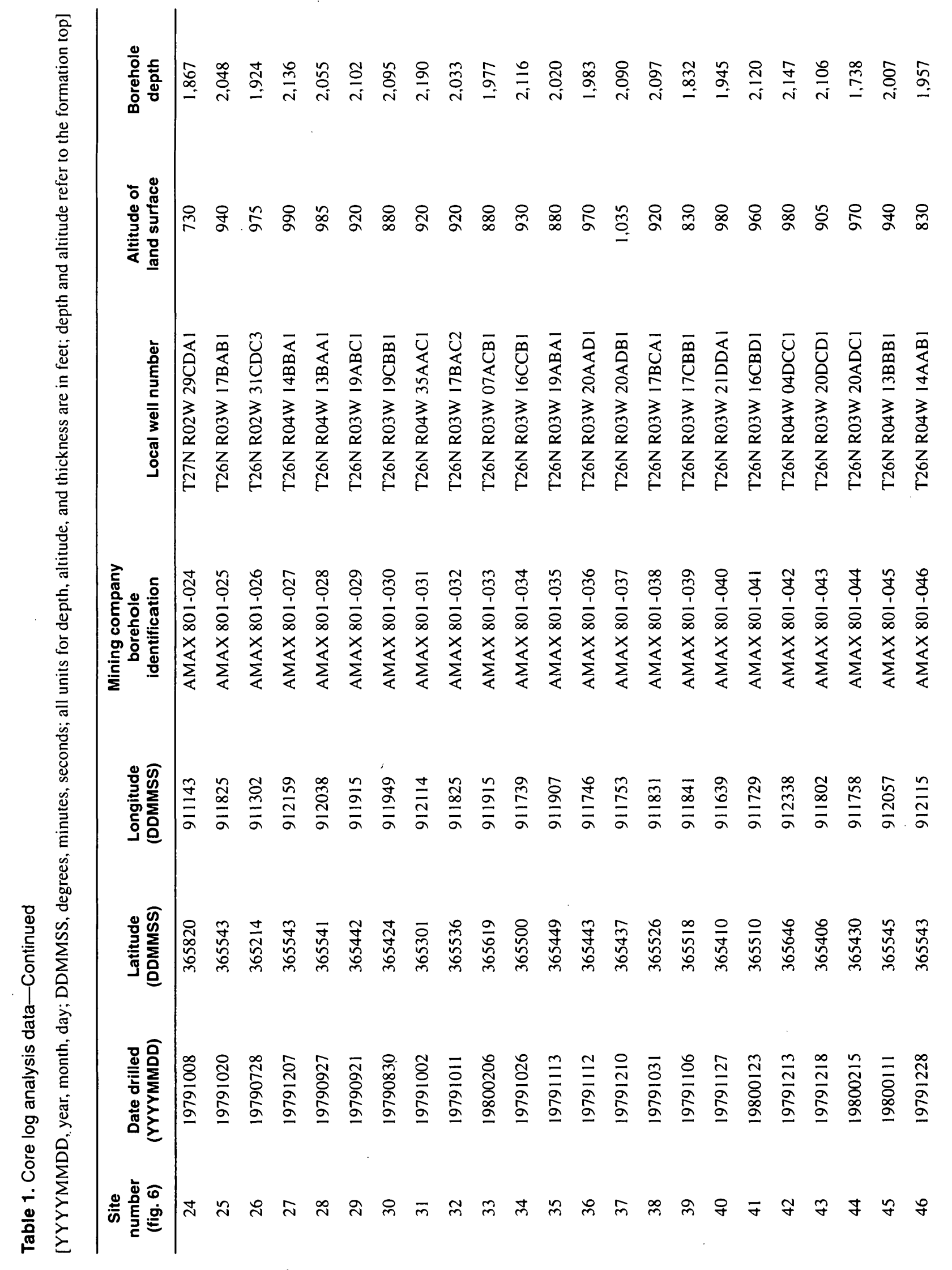




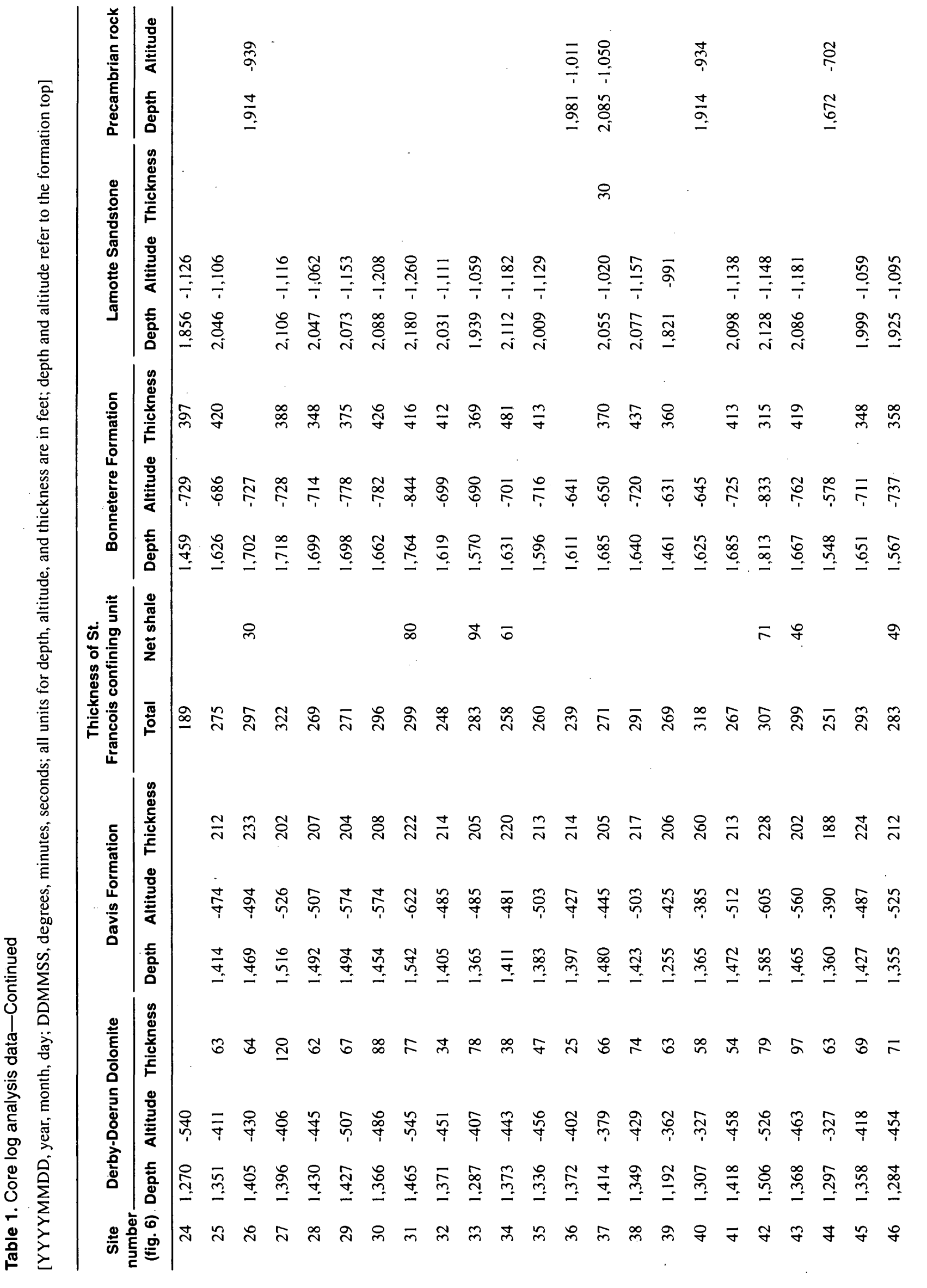




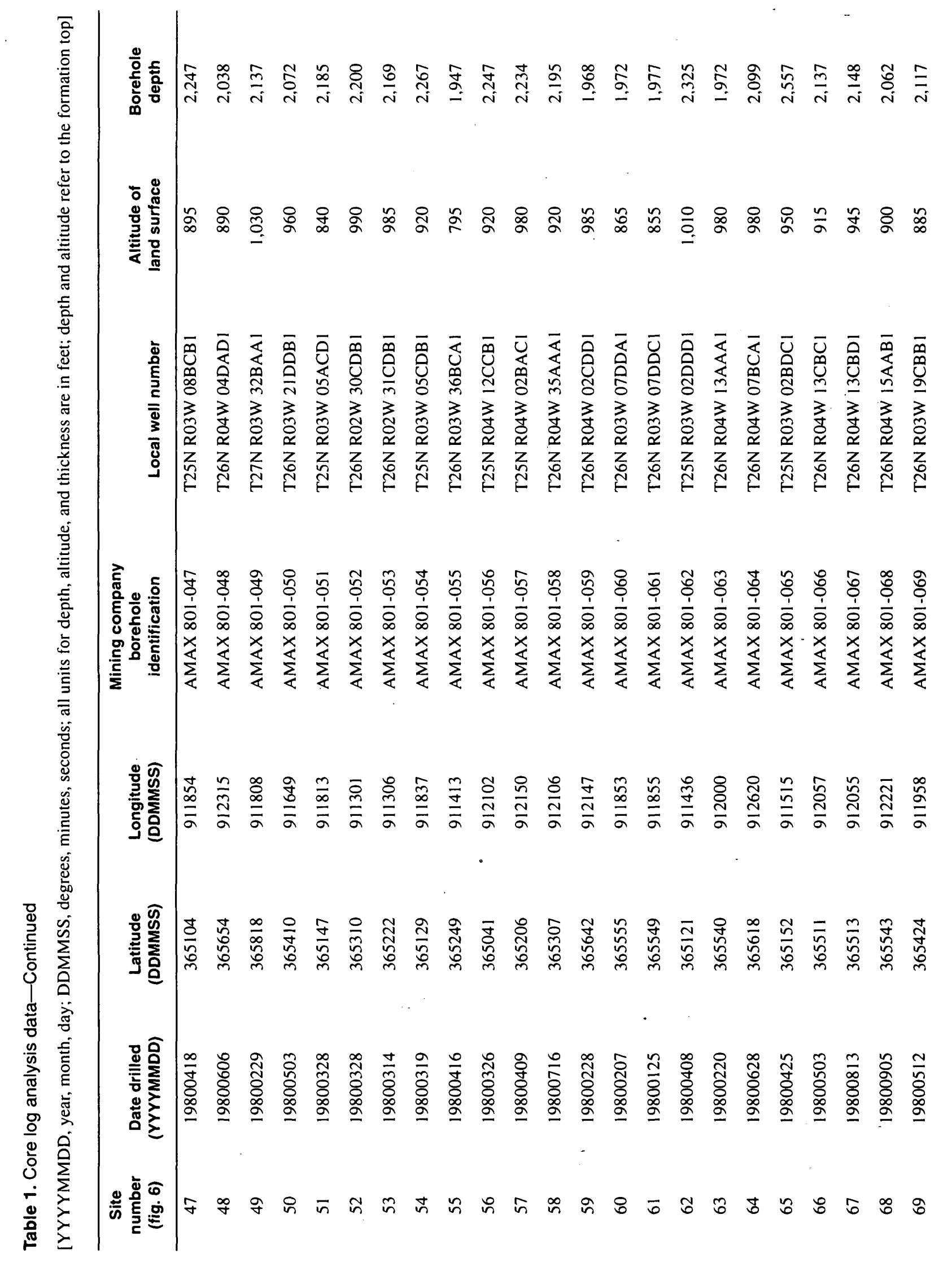




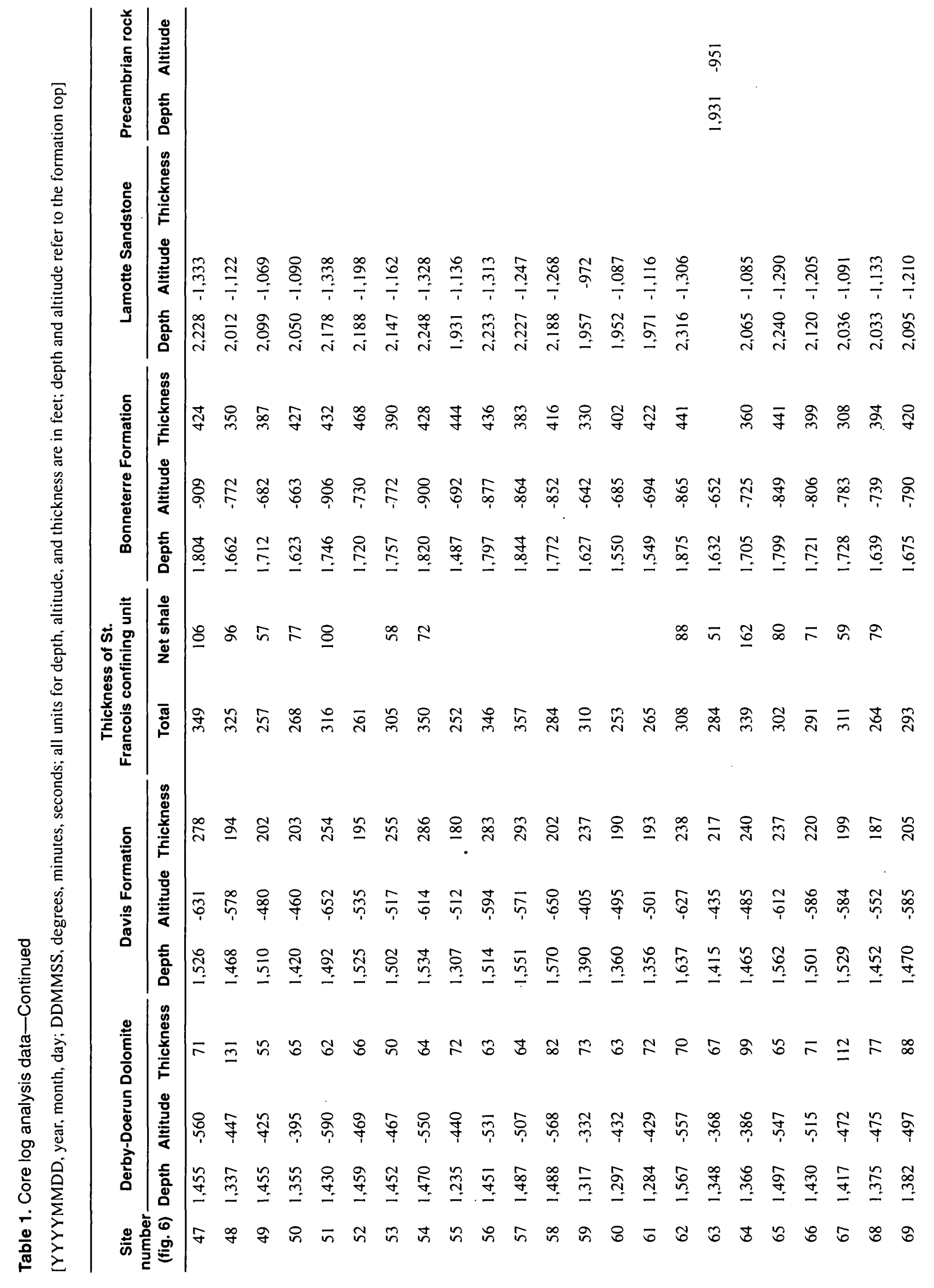




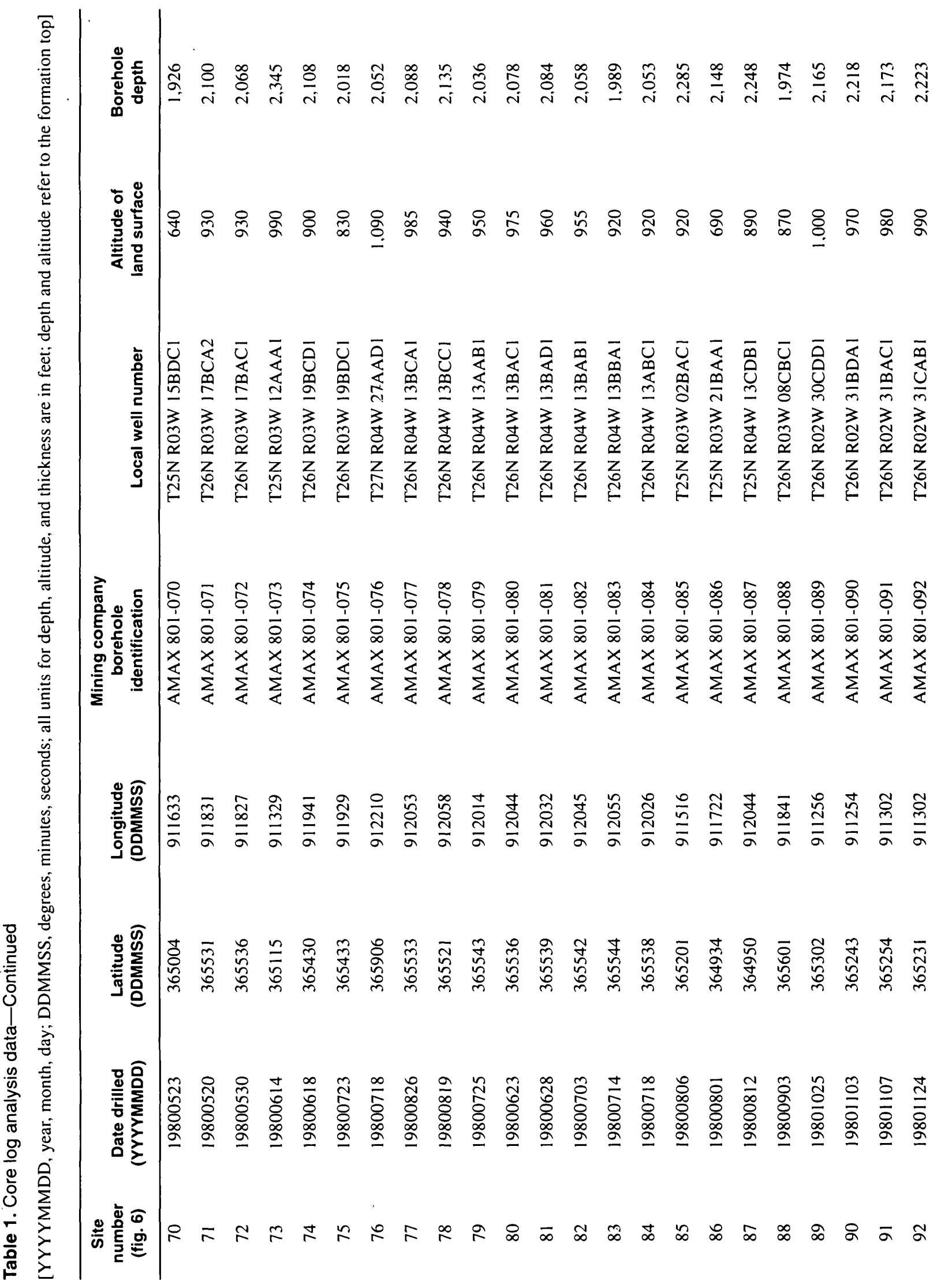




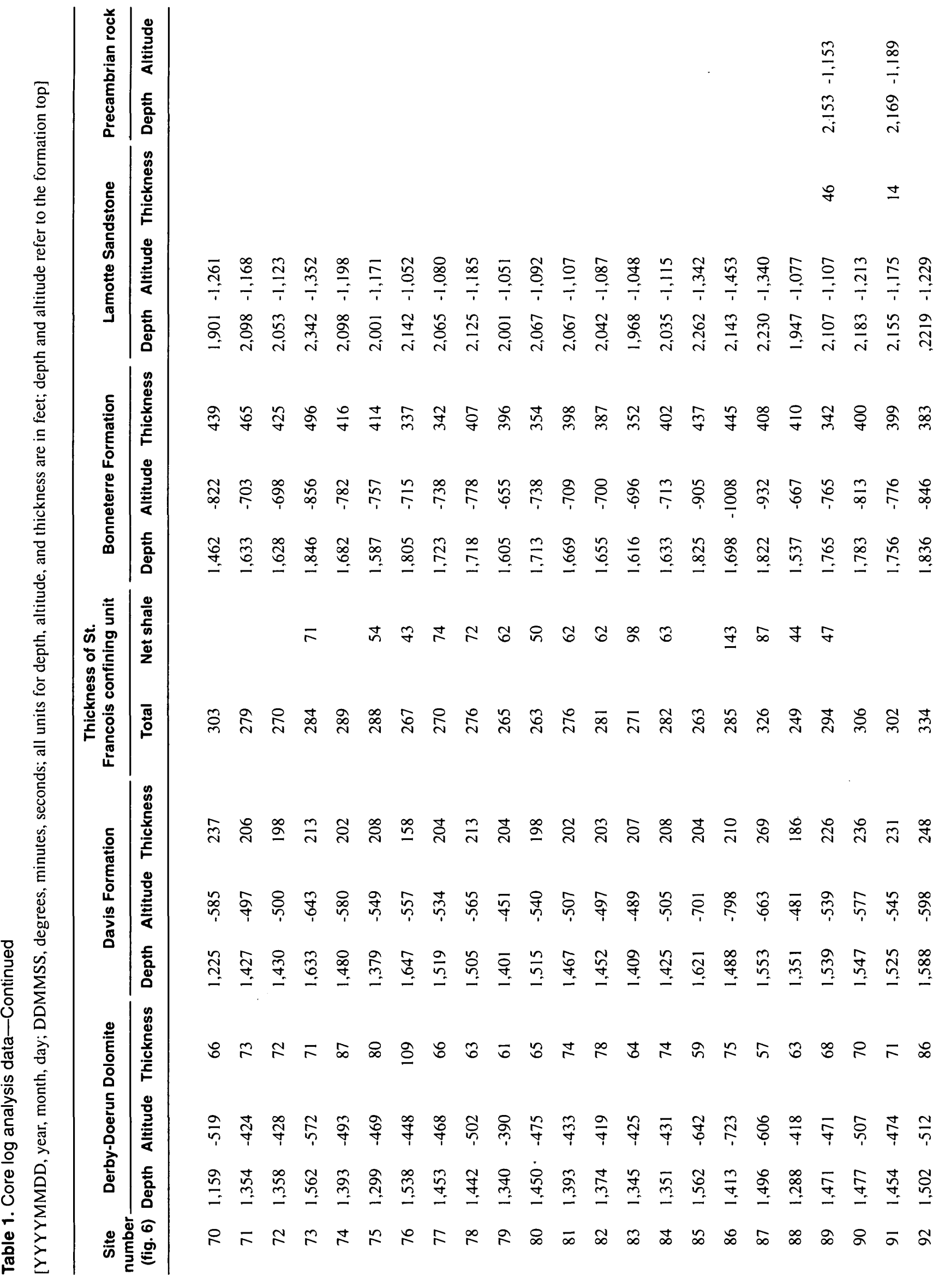




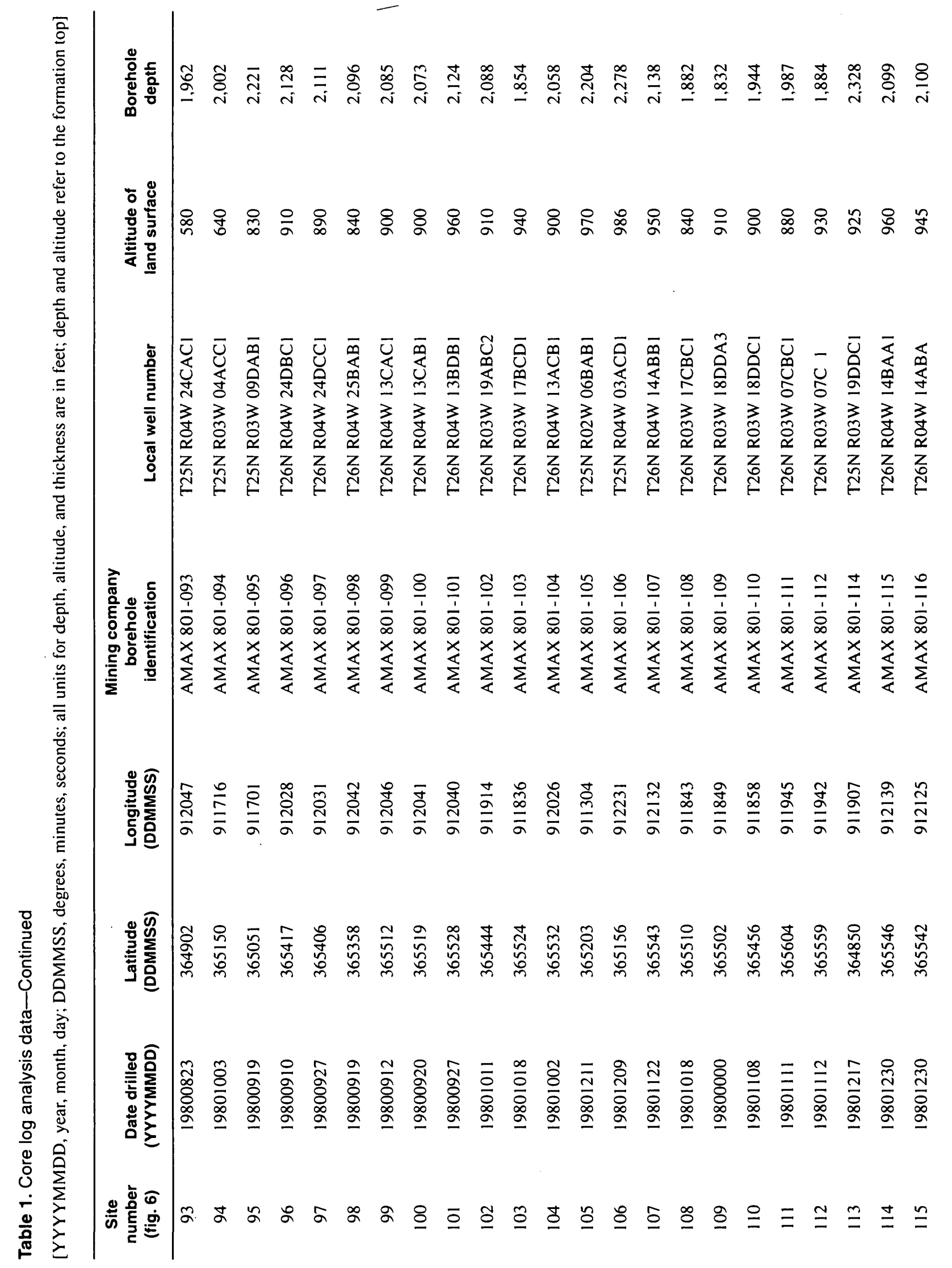




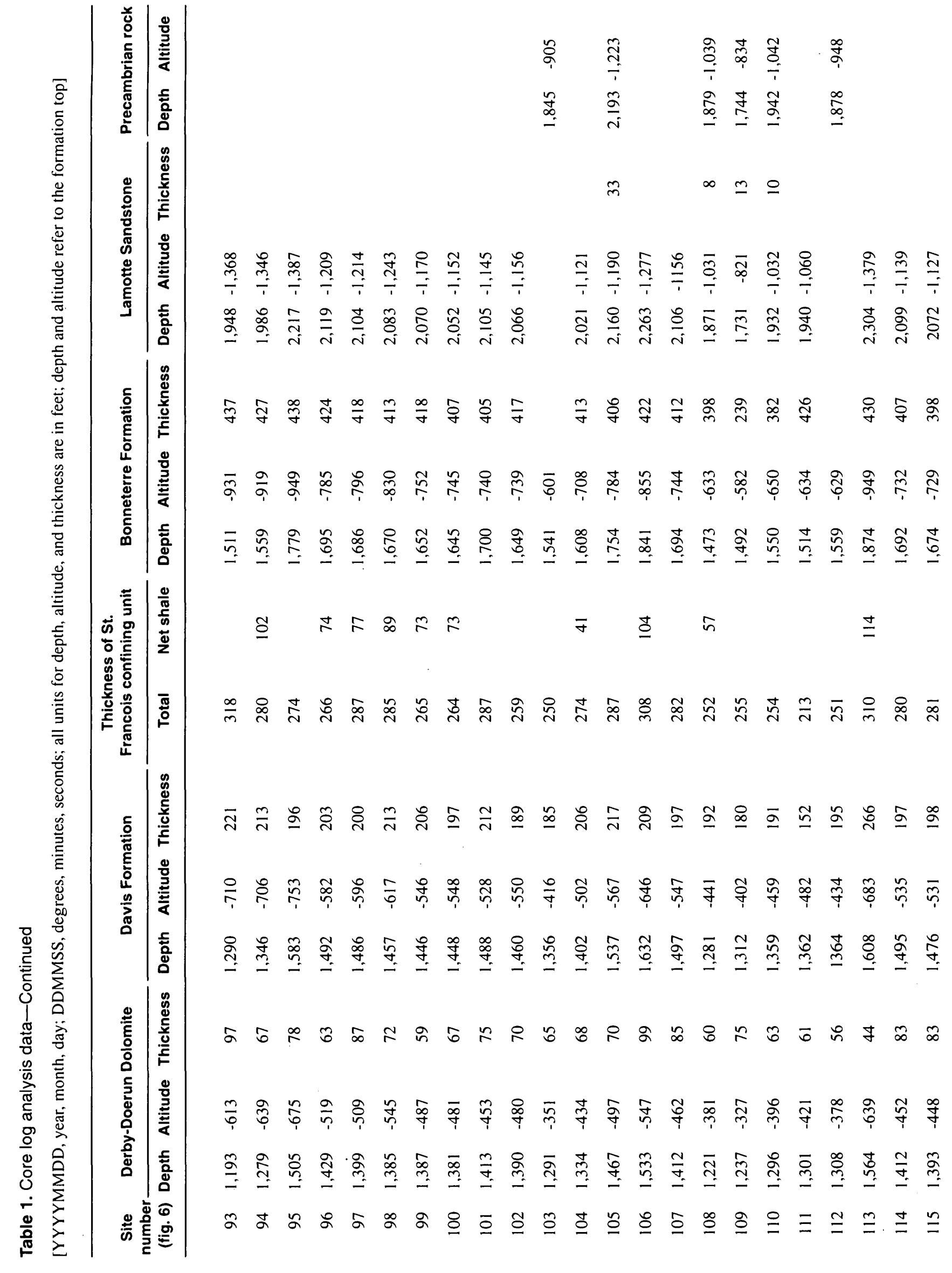




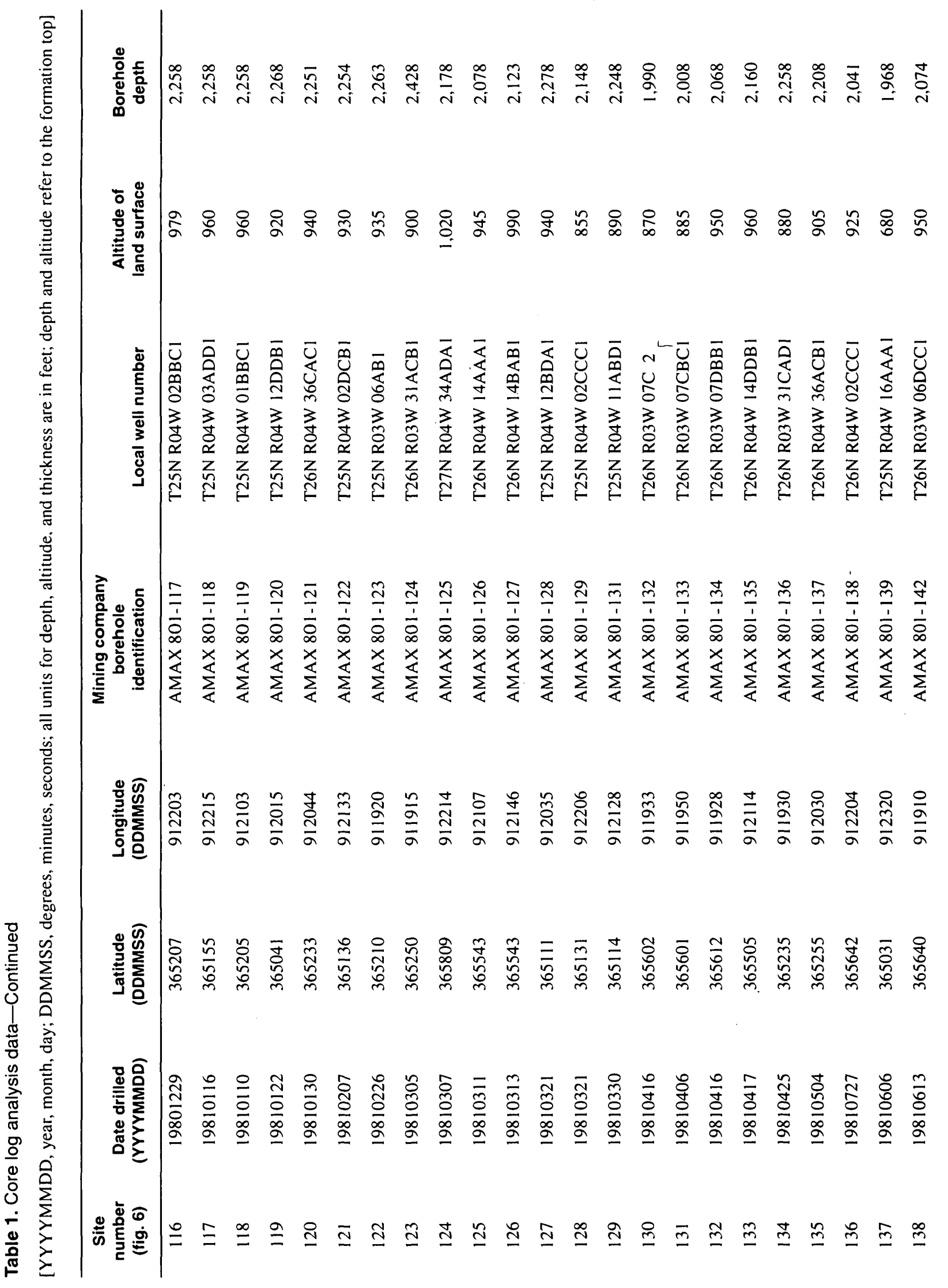




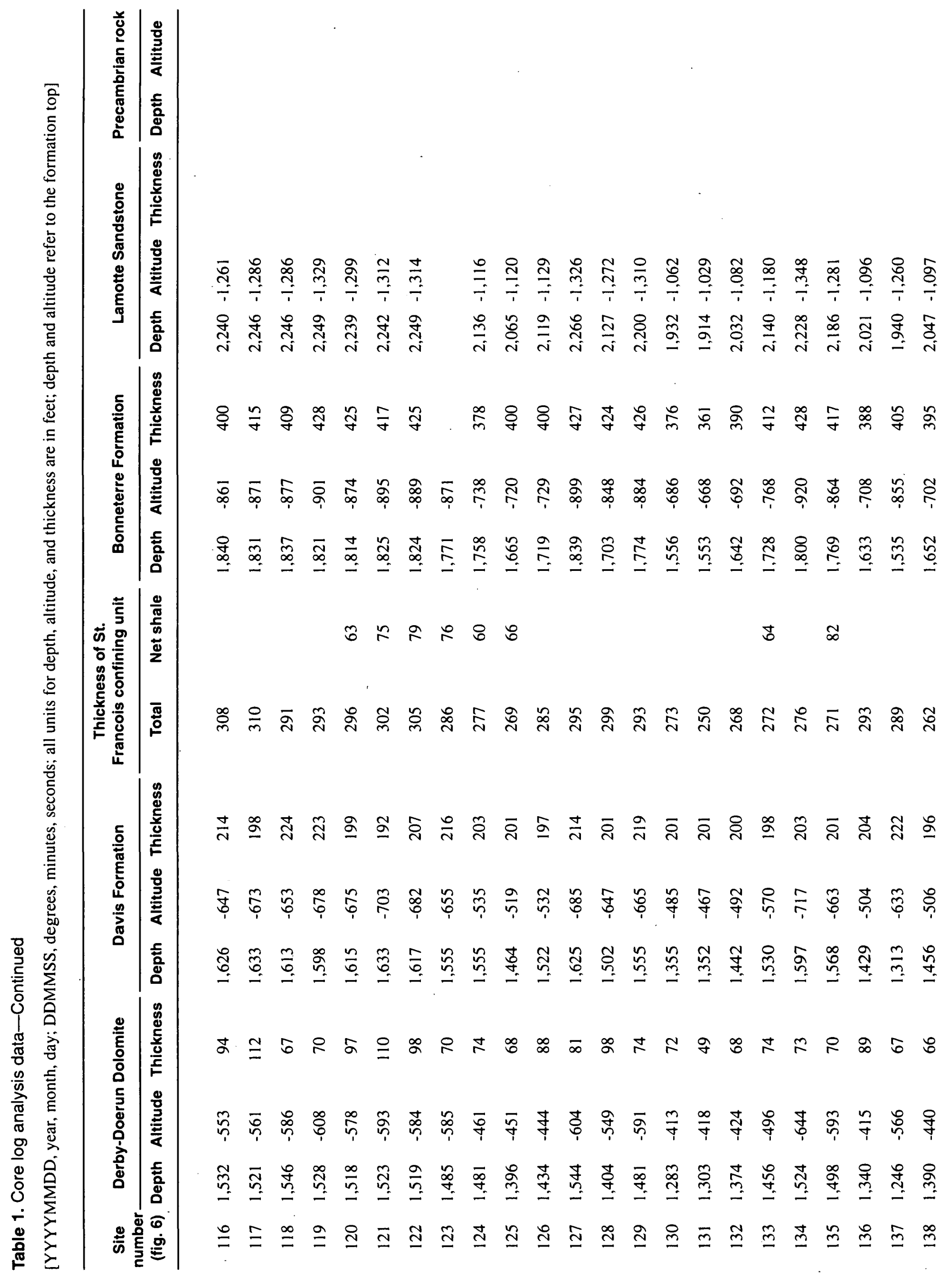




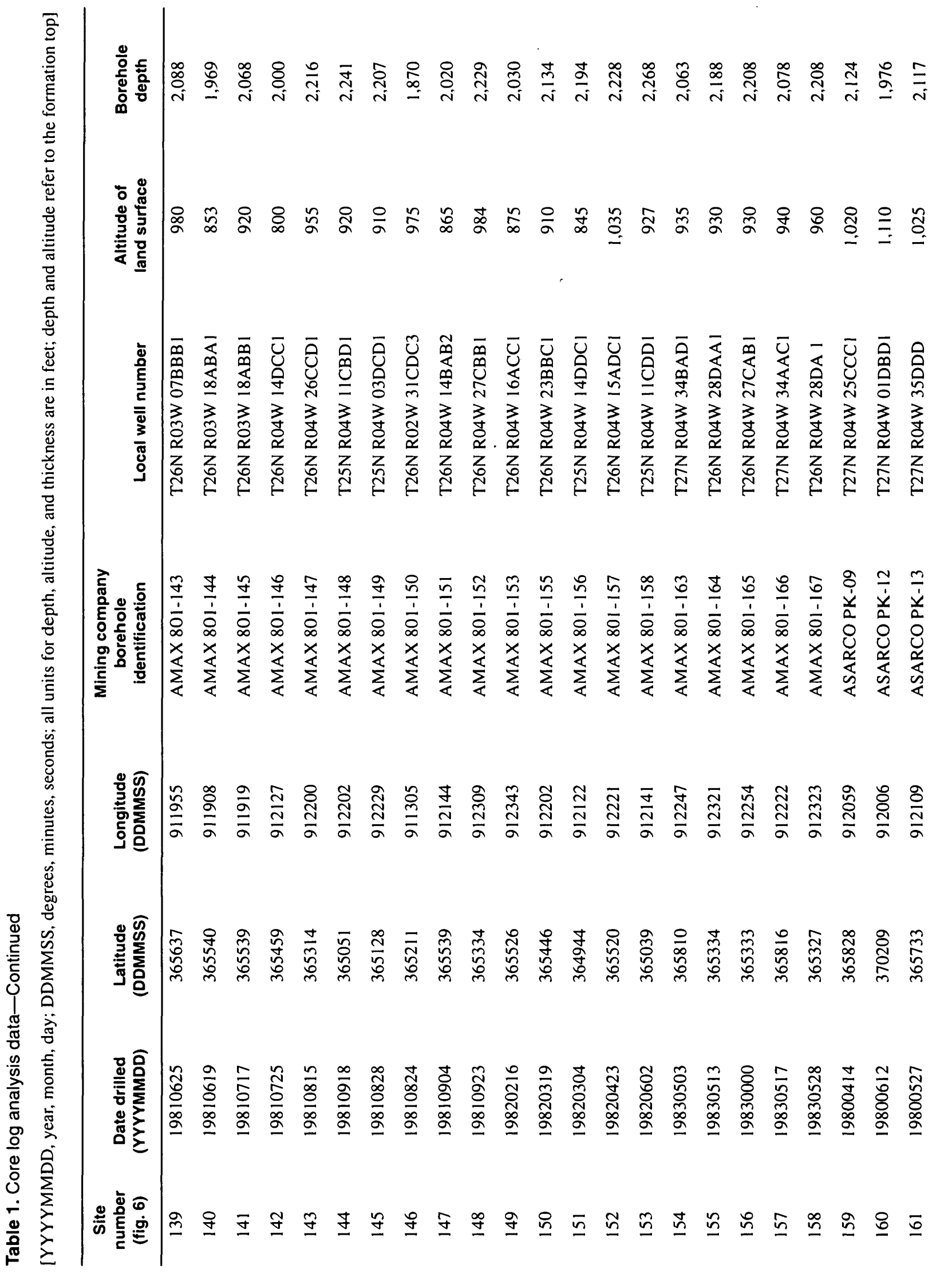




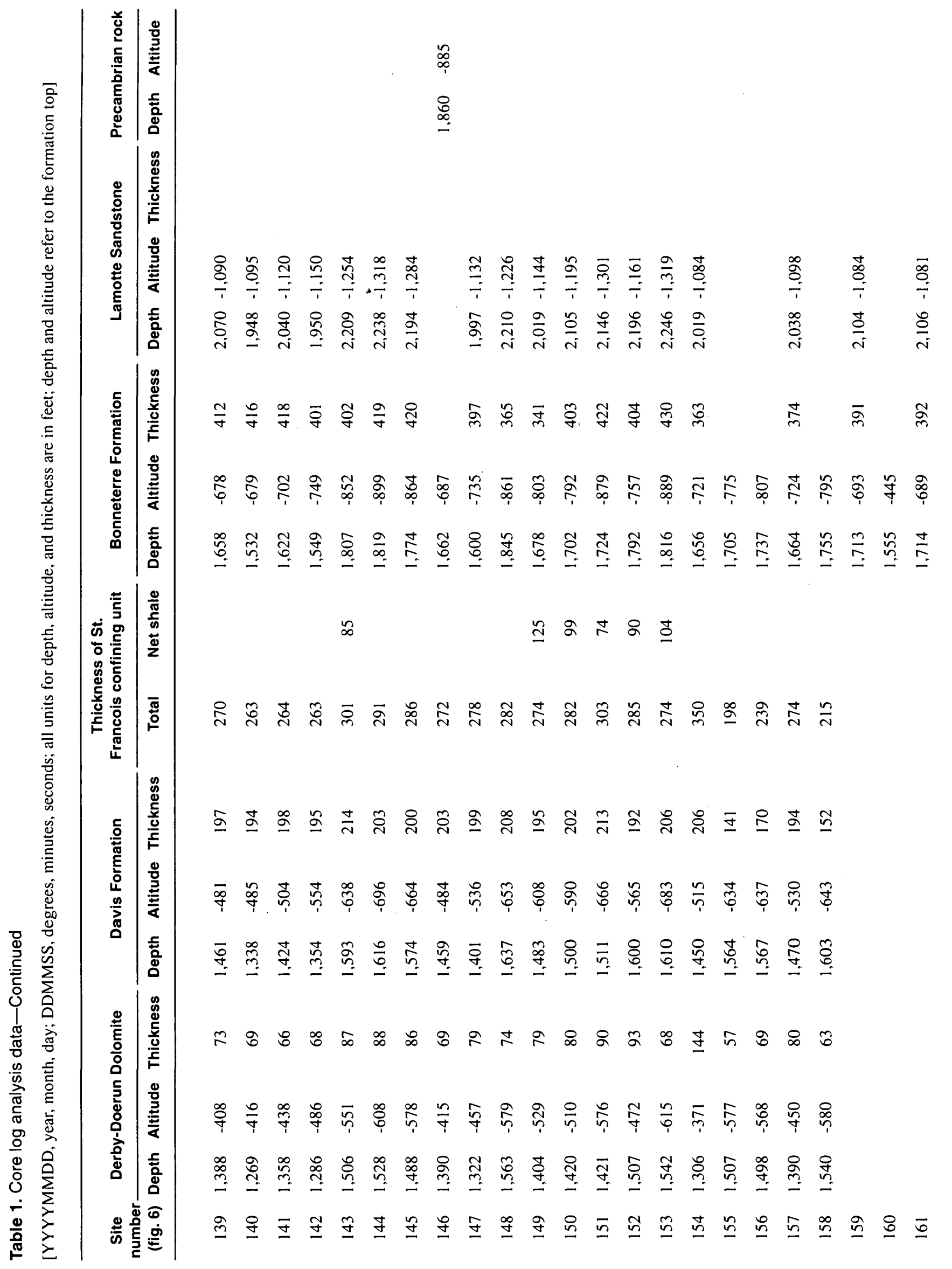




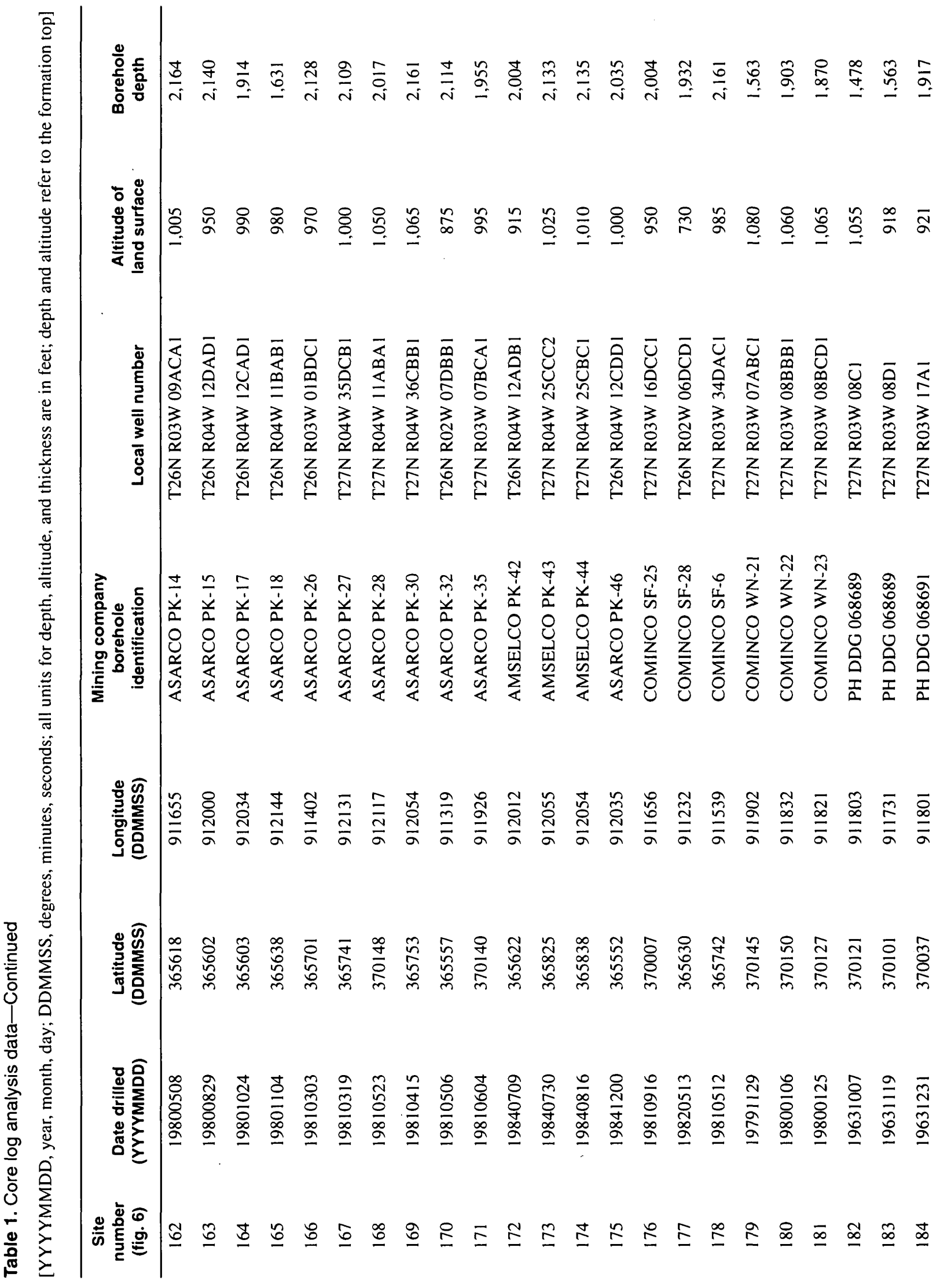




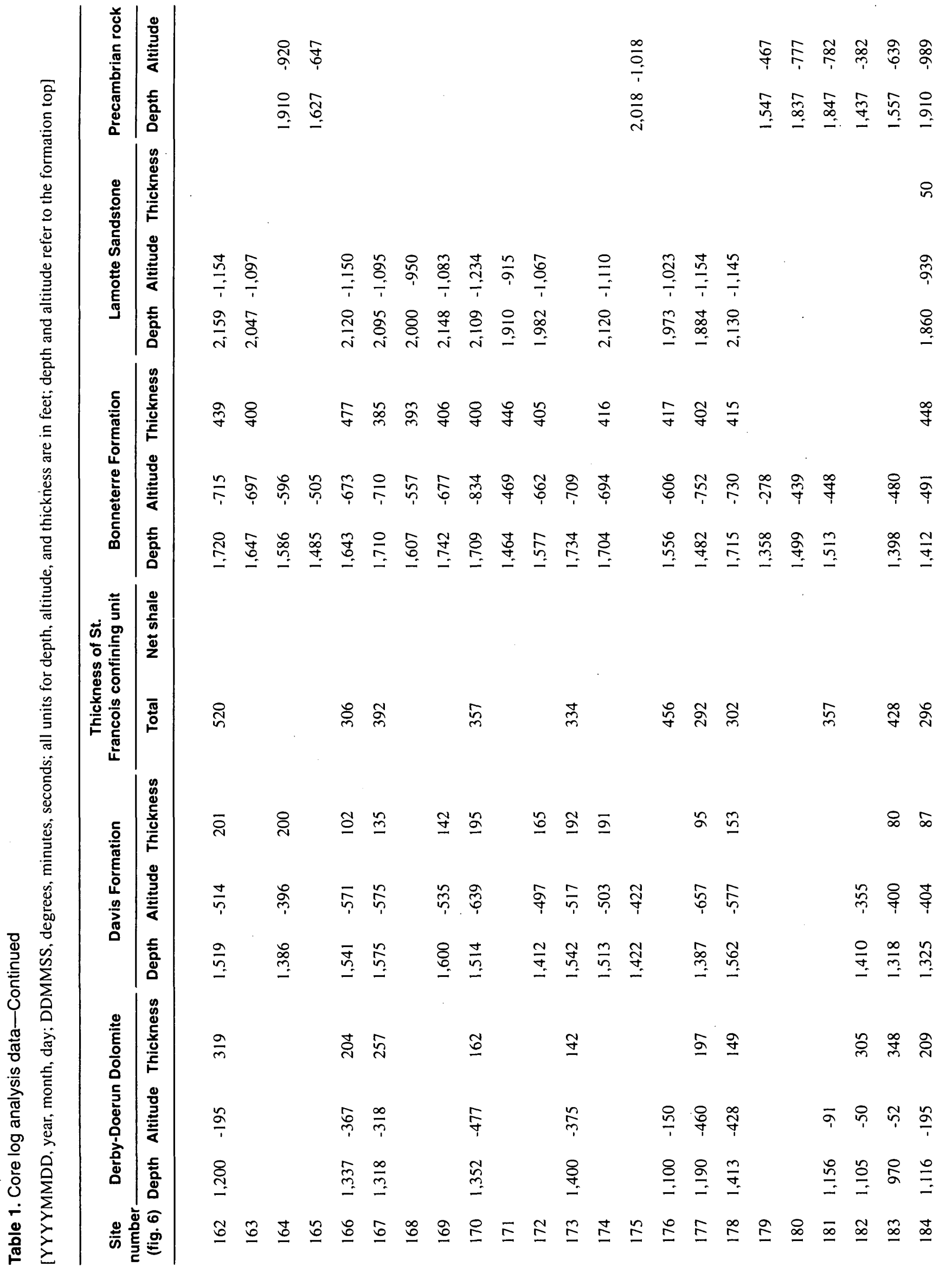




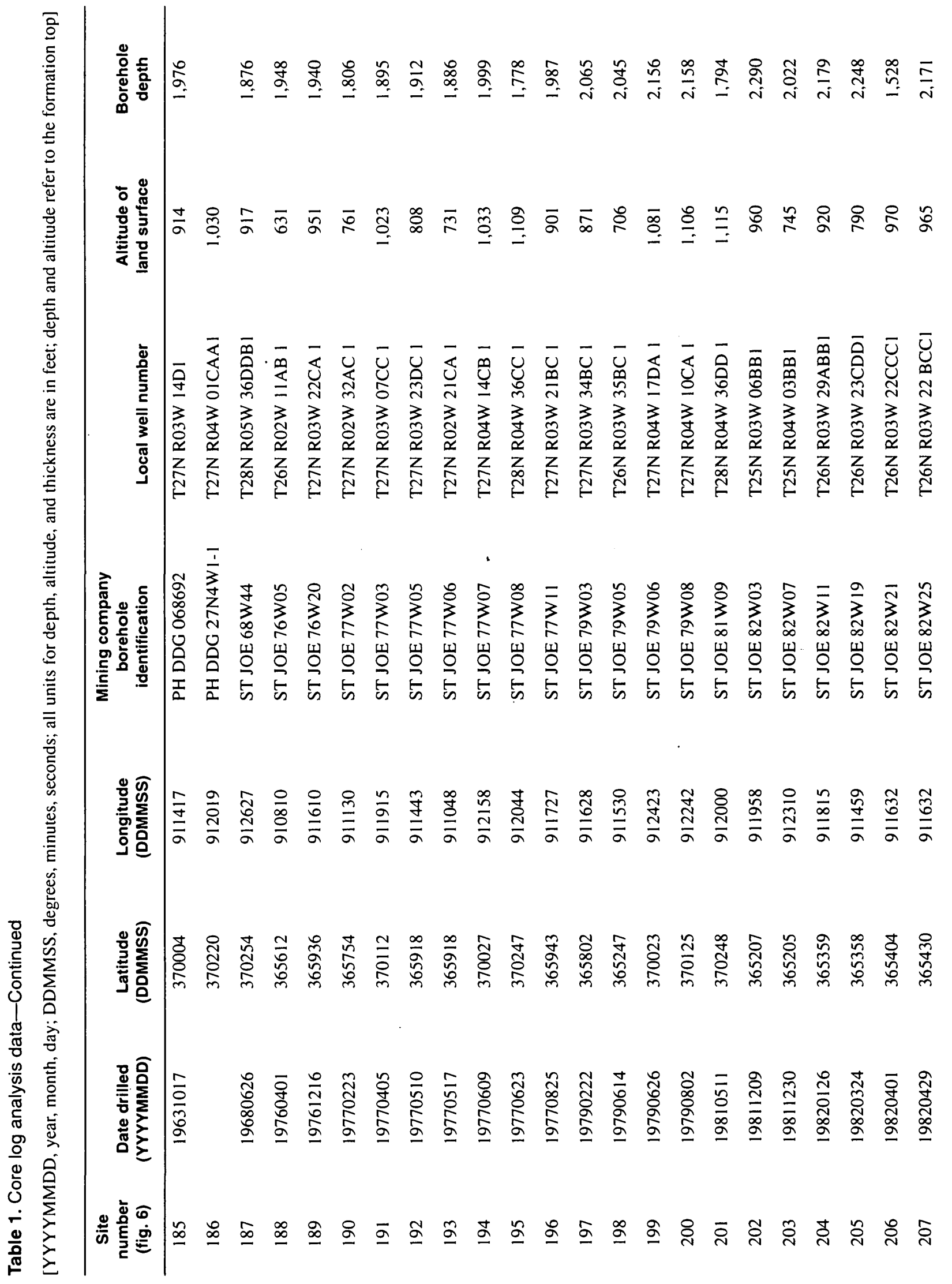




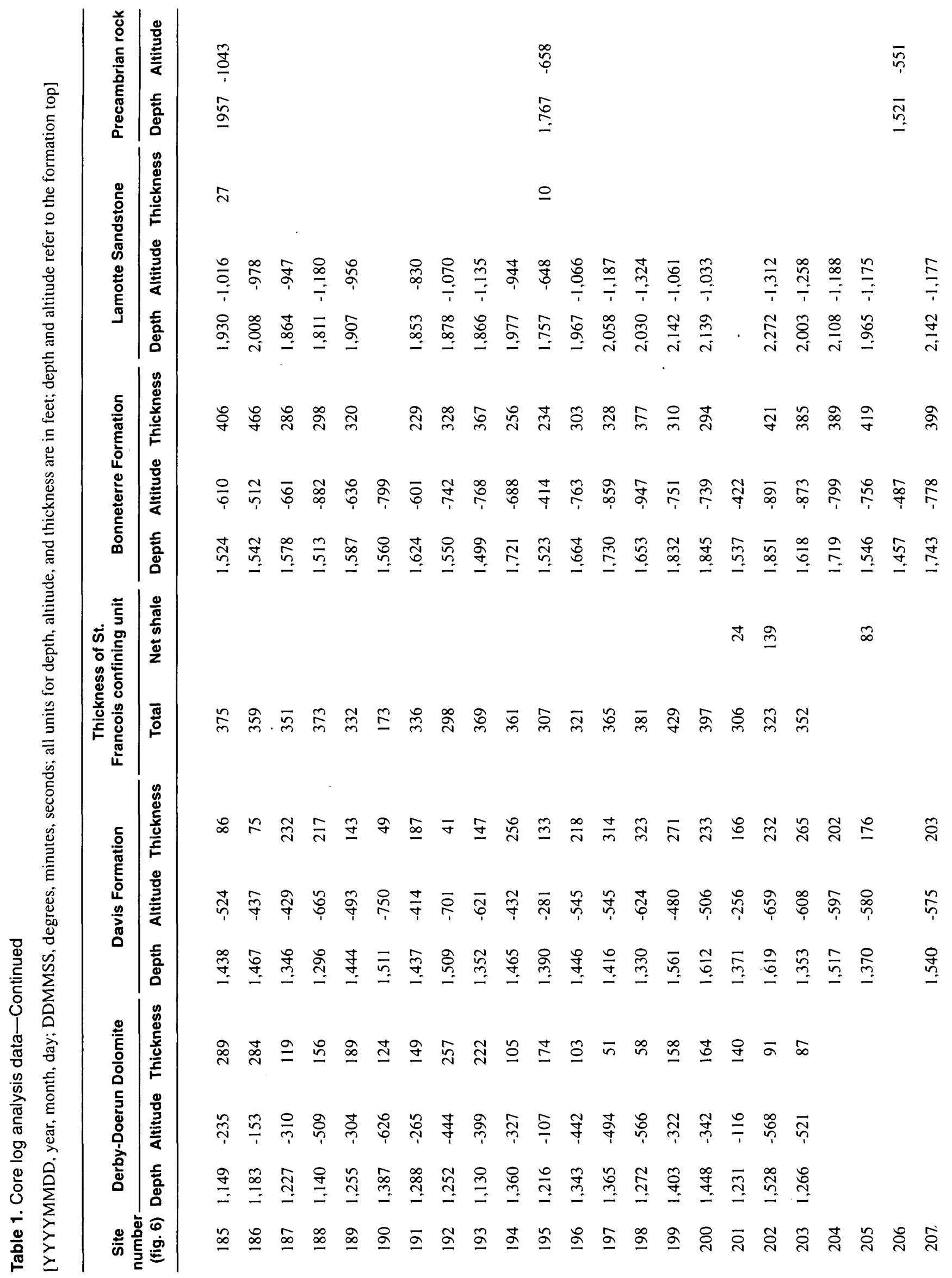




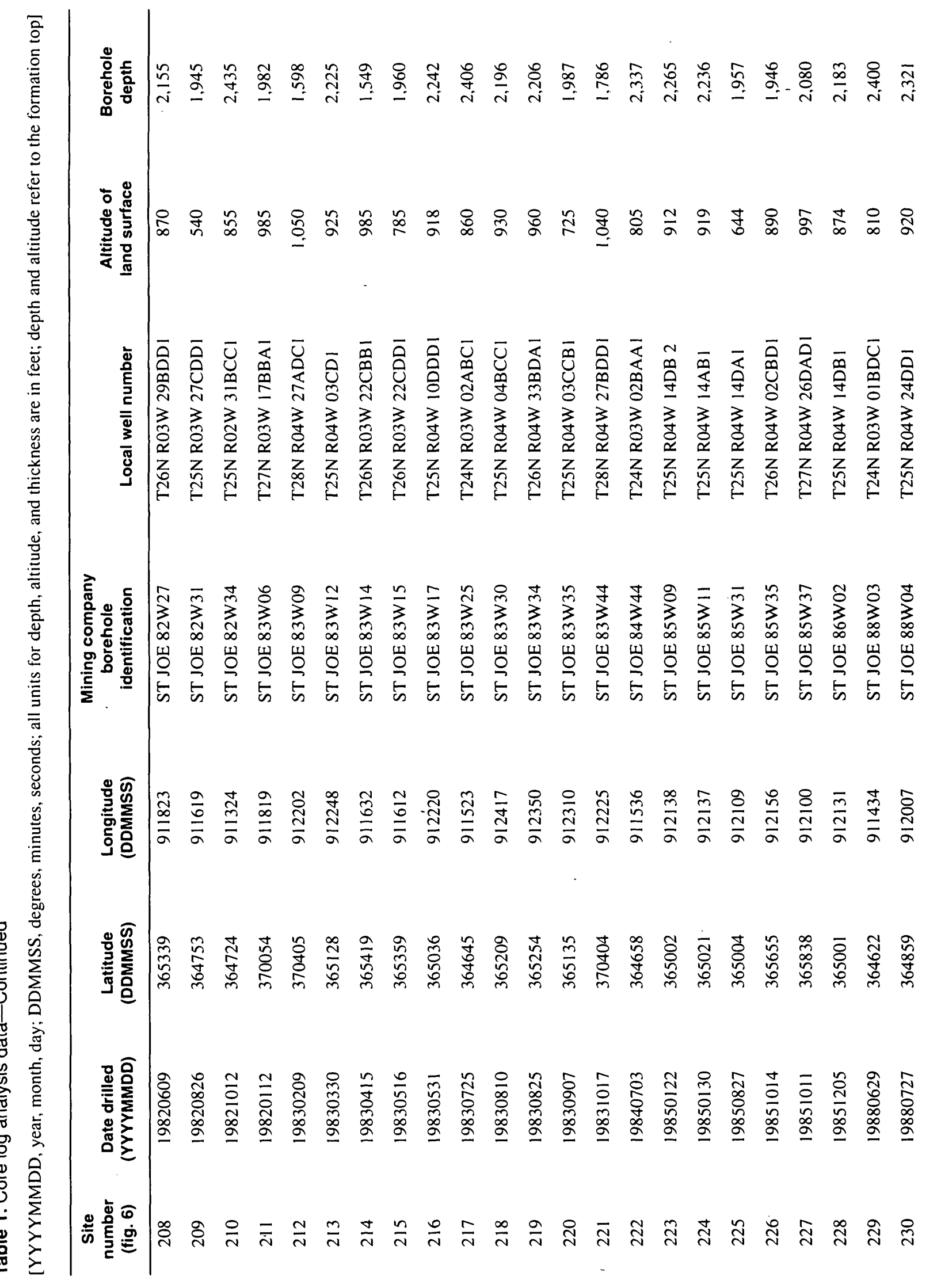




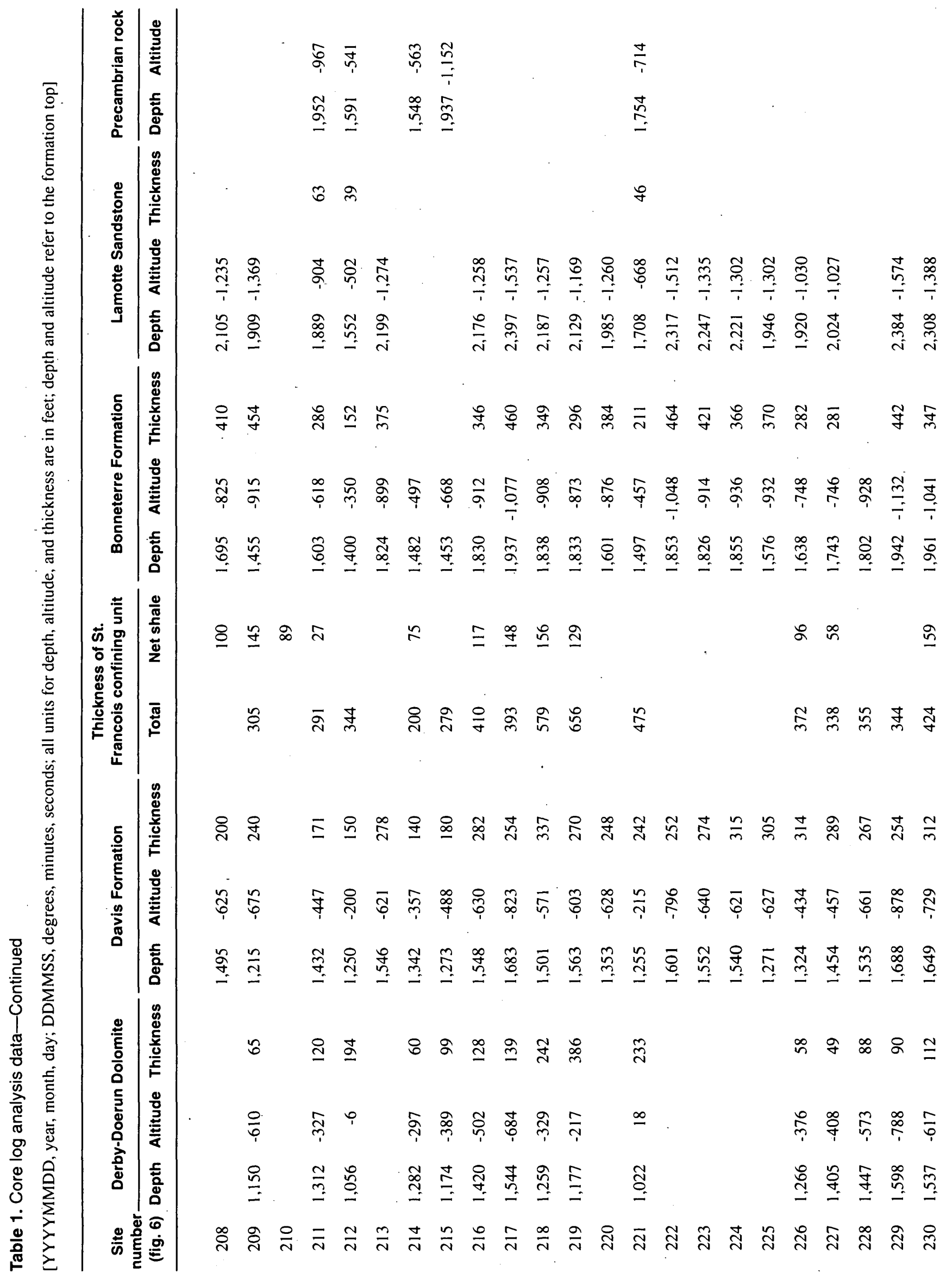




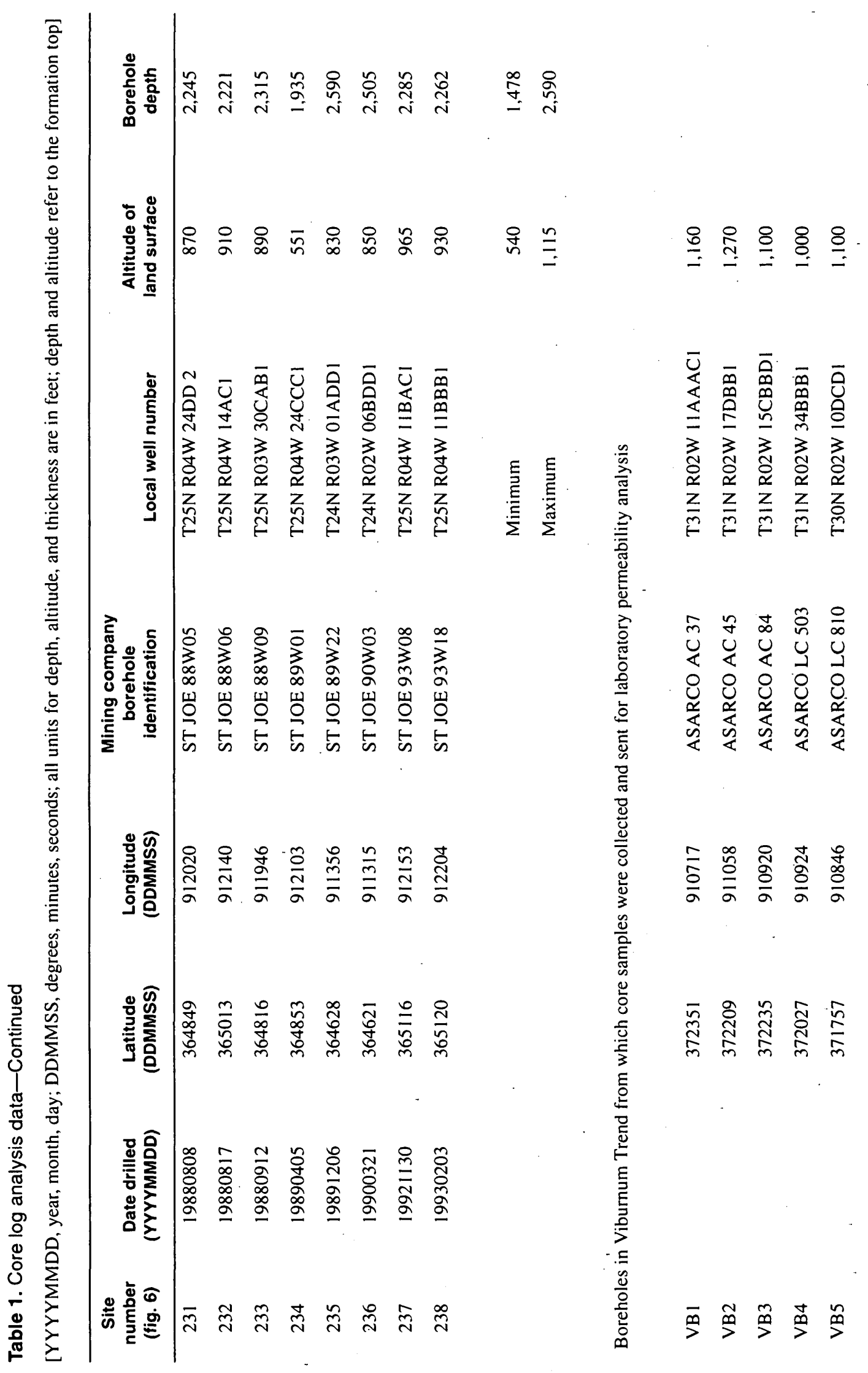




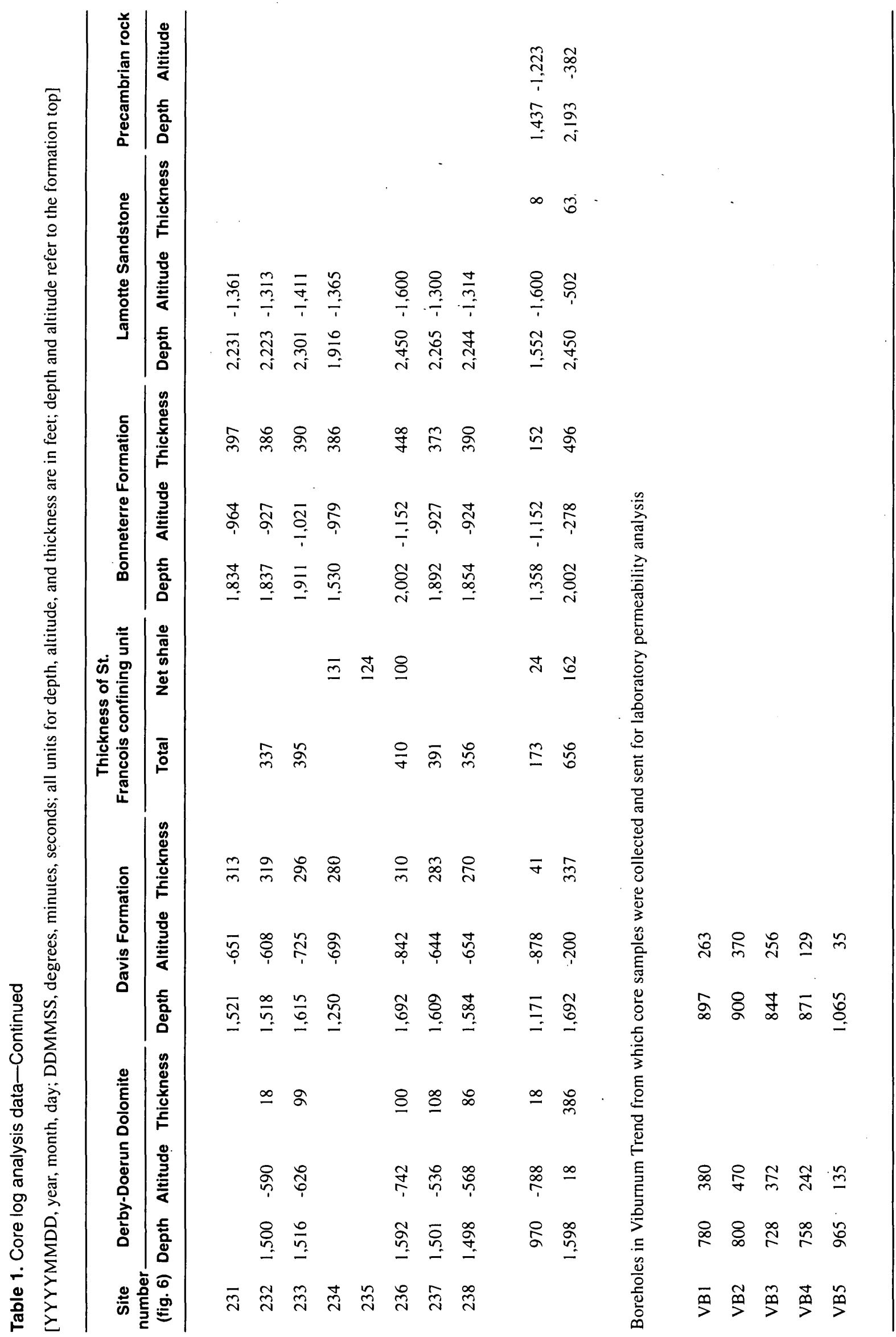




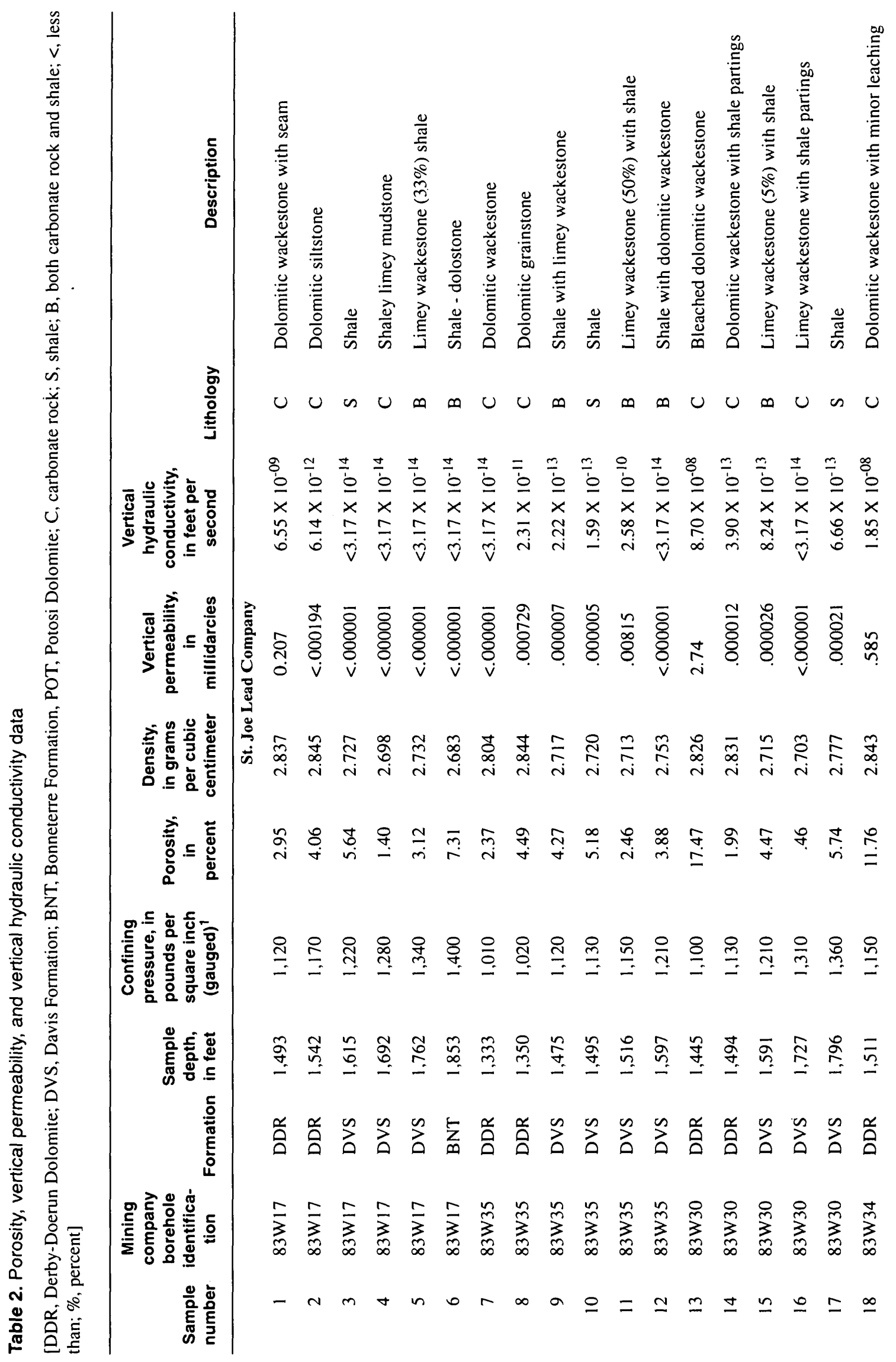




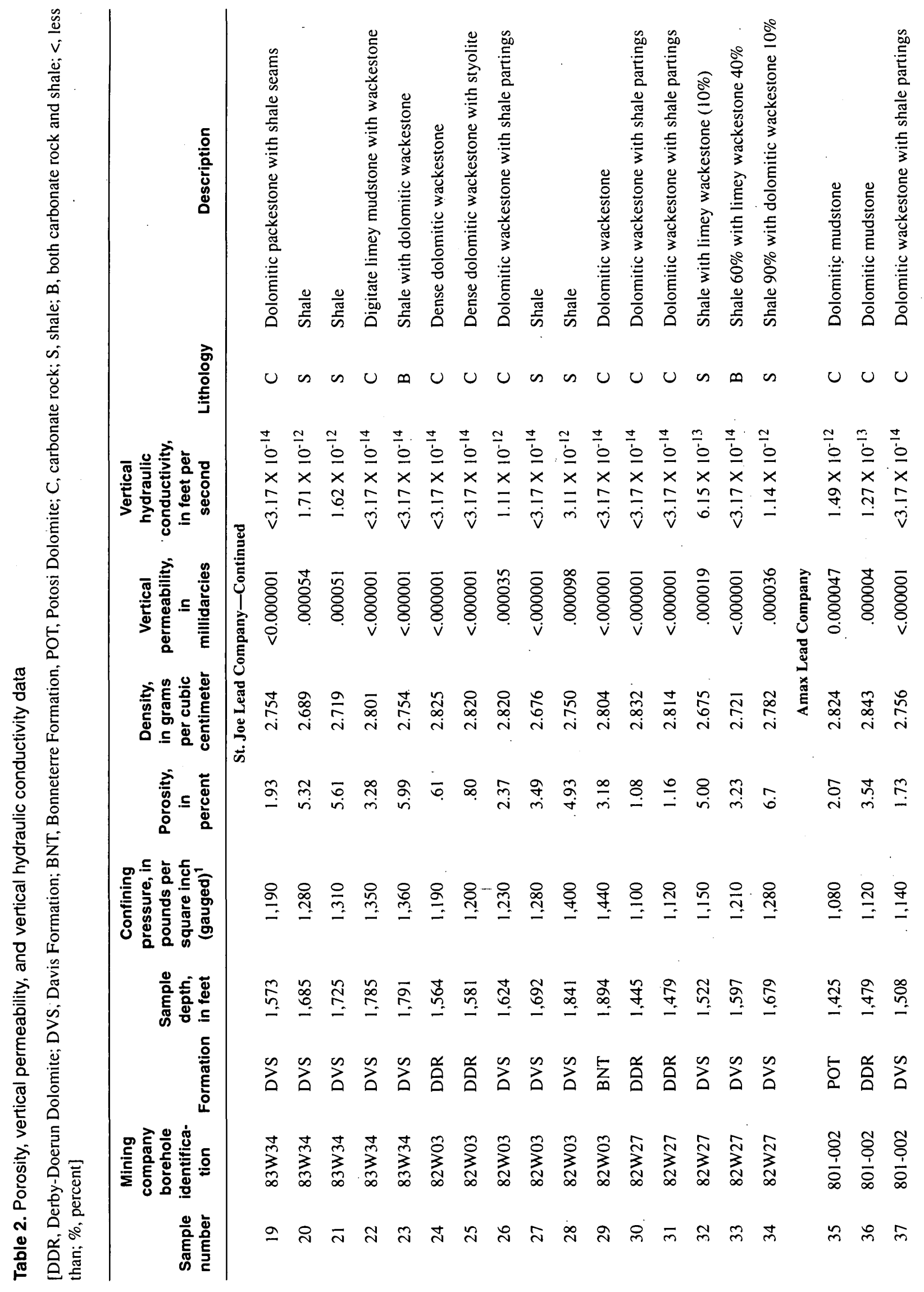




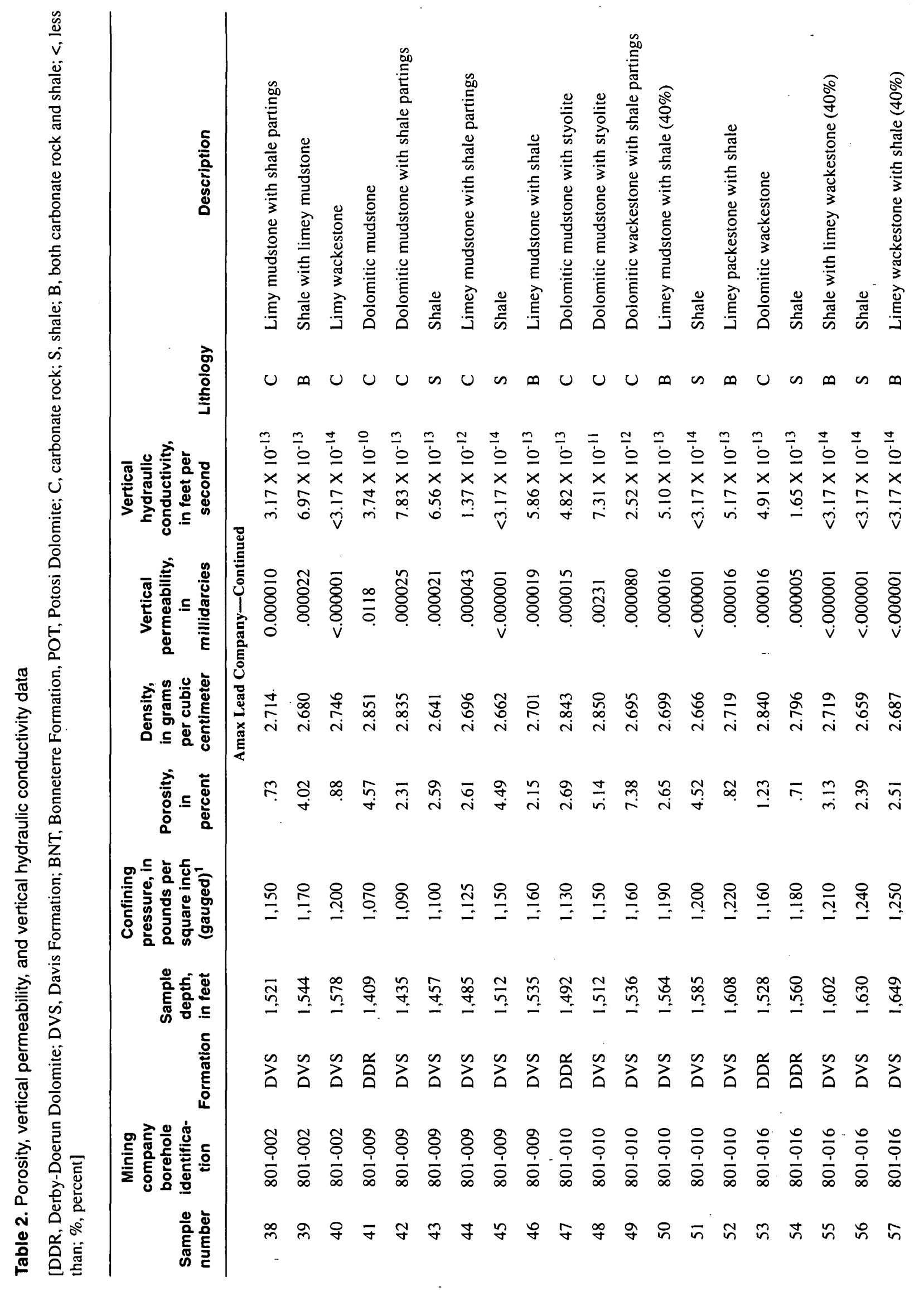




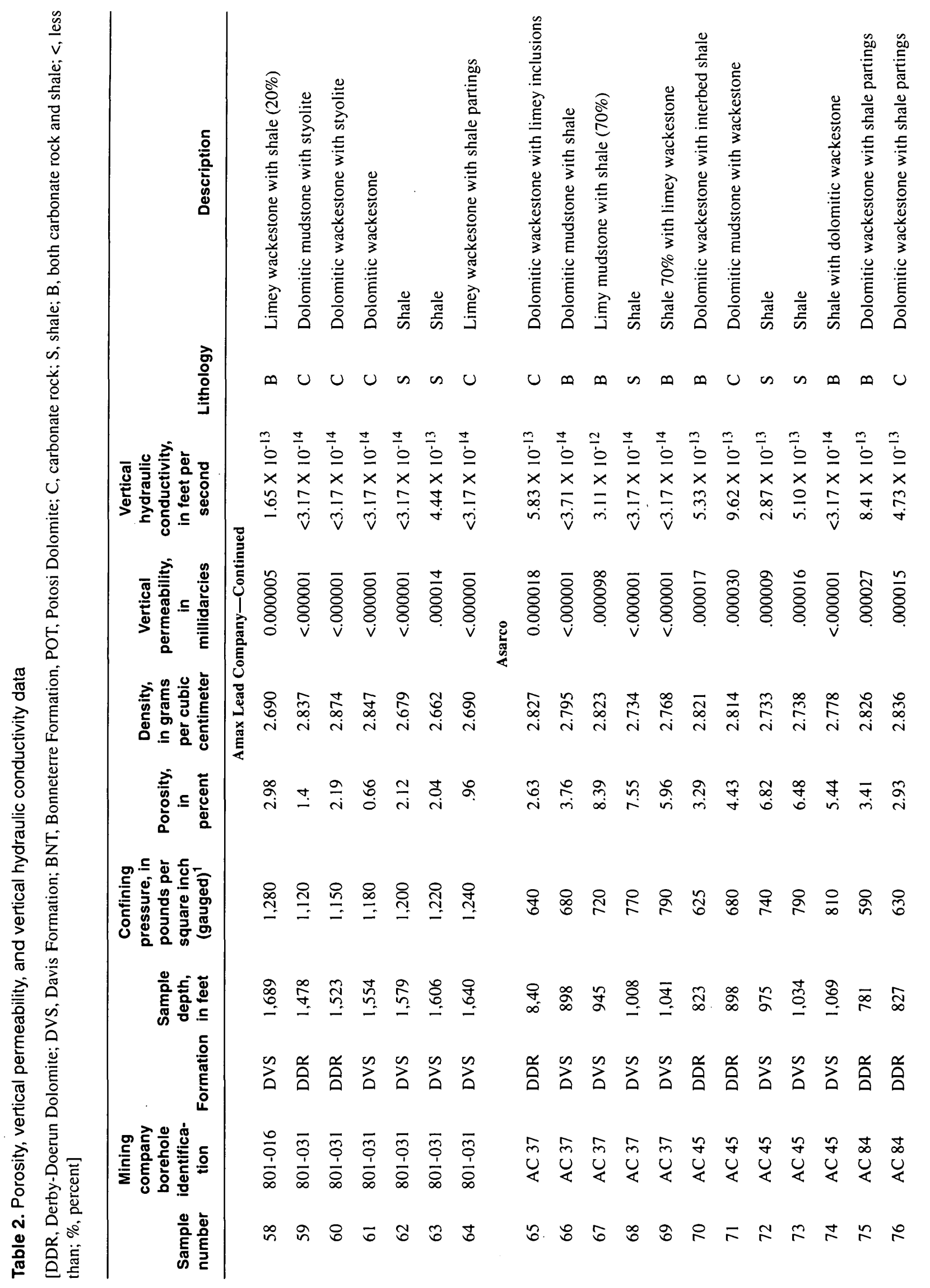




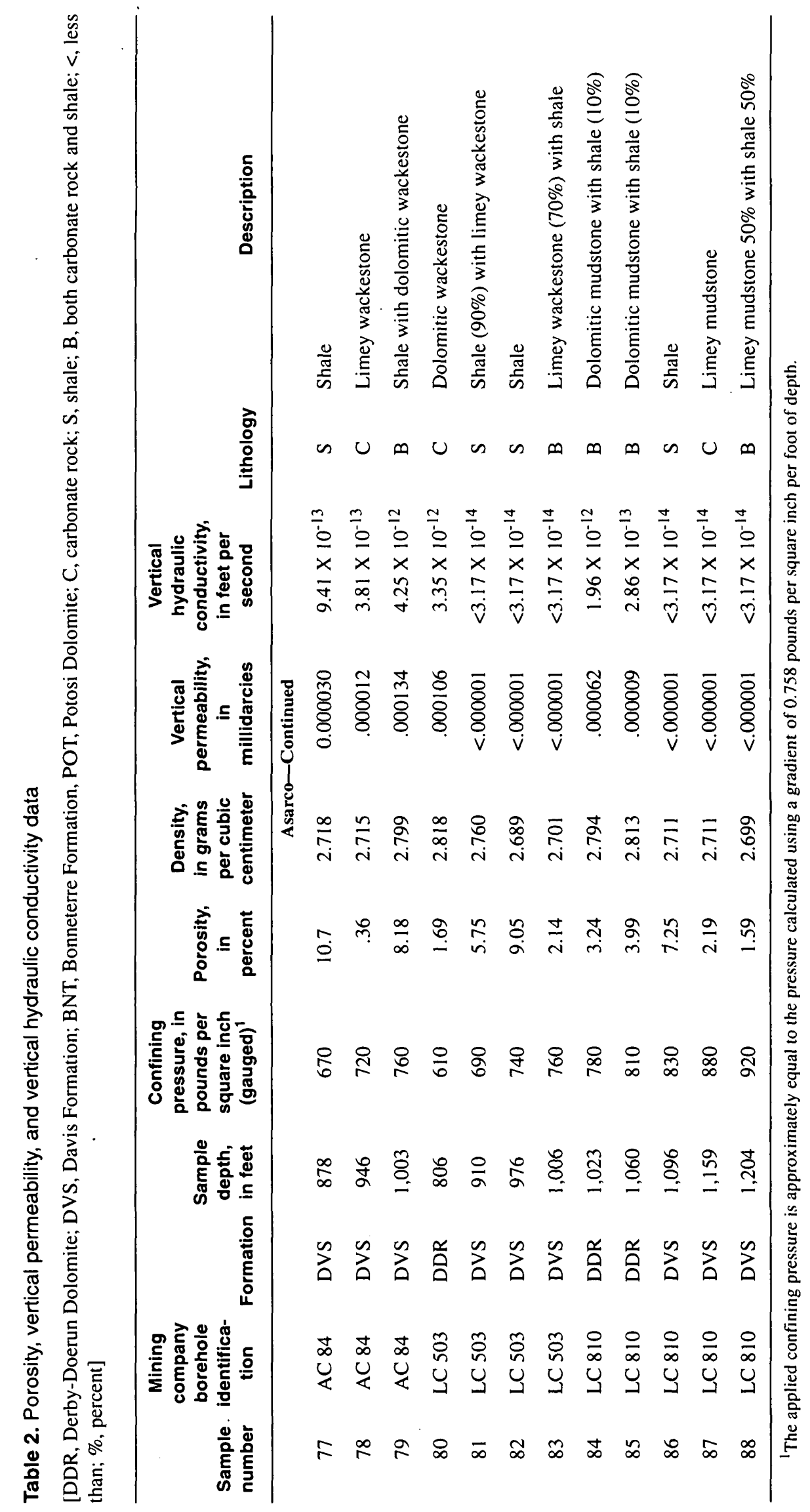




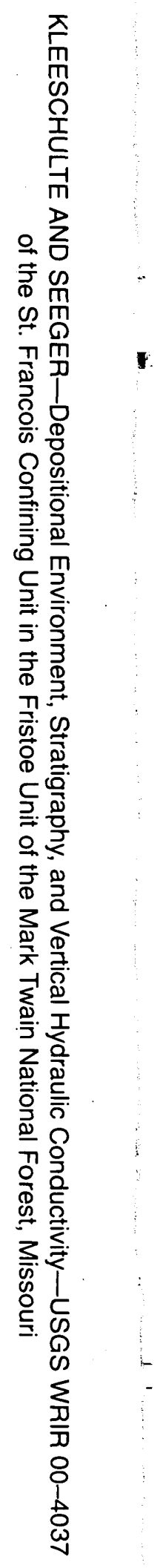

(4) Printed on recycled paper 